\title{
"YOUR MOST AFFECTIONATE GOOD SISTER": RHETORIC, DIPLOMACY AND SELF-PRESENTATION IN THE LETTERS OF MARY, QUEEN OF SCOTS
}

\author{
by
}

\section{BETHANY PEHORA, B. Hums Honours}

\author{
A thesis submitted to \\ the Faculty of Graduate and Postdoctoral Affairs \\ in partial fulfillment of \\ the requirements for the degree of \\ Master of Arts \\ Department of History
}

\author{
Carleton University \\ Ottawa Ontario \\ August 3, 2021 \\ (C) copyright \\ 2021, Bethany Pehora
}




\begin{abstract}
This thesis examines letters of Mary Stuart, Queen of Scotland, showing her as an accomplished rhetorician. Mary's letters have gone largely unexamined by scholars, despite the new interest in the writing of women in the early modern period. In her letters she used appeals to kinship, emphasis on rank, calls to shared religion and expressions of emotion in order to support specific objectives for her letters. The flexibility and variety of the rhetoric contained within the letters from across her life show Mary to be an accomplished and competent rhetorician. The epistolary exchanges examined in this thesis were essential in maintaining Mary's diplomatic networks both during her reign and after her abdication. The letters examined in this thesis come from both published collections of Mary's letters from the nineteenth century and from original transcriptions of archival material of letters than have not been previously published or examined.
\end{abstract}




\section{Acknowledgements}

Though the research for this thesis was largely completed in isolation, in the midst of a pandemic, it was hardly completed alone.

Thank you to the staff in the digitization department at the British Library for their assistance with accessing archival material oceans away. Thanks also to David Dean for his patience in paleography lessons over coffee. I am deeply indebted to the staff and faculty of both the History Department and the College of the Humanities, especially Joan White and Andrea McIntyre for their wisdom and support.

Endless gratitude goes to Meghan for always being willing to talk about 'our Marys' and for always supporting me and encouraging me. Thank you to all four of my parents; Lorraine, Guy, MJ and Paul, for their faith in my abilities and joy in seeing me do what I love. I am also extremely indebted to Max, Emma and Victoria for their weekly support and for their love of adventure.

A special thank you to my supervisors, Paul Nelles and Micheline White for their support, encouragement and insight. 


\section{Table of Contents}

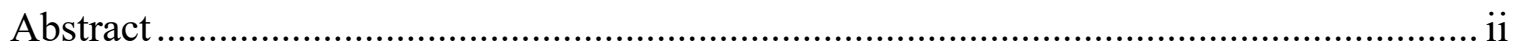

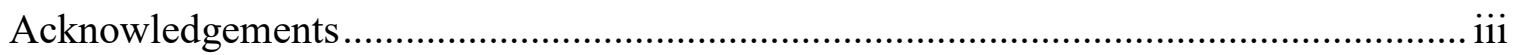

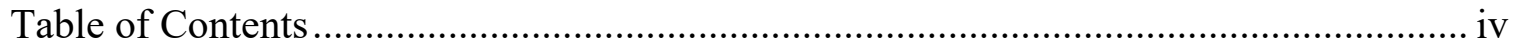

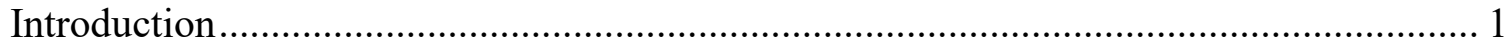

Chapter One: Writing Diplomatic Relationships in Mary's Personal Reign ................... 28

Chapter Two: Rank, Kinship and Justice in the Letters of a Captive Queen................... 59

Chapter Three: A Persecuted Prince in the Casket Inquiry ........................................... 89

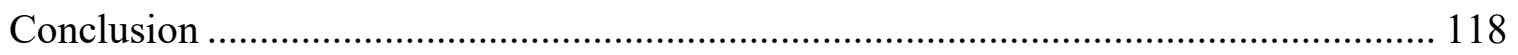

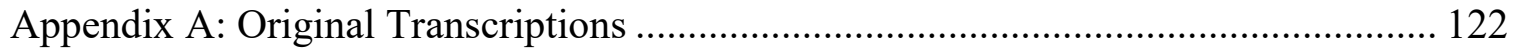

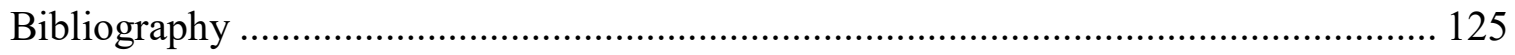




\section{Introduction}

"But God, through his infinite goodness, has preserved me, and I escaped [...] into your country, being assured that, hearing the cruelty of my enemies, and how they have treated me, you will, conformably to your kind disposition, and the confidence I have in you, not only receive for the safety of my life, but also aid and assist me in my just quarrel."1

In the small coastal town of Workington, in mid-May of 1568, an anointed queen, who had fled from her own country in order to preserve her own life, put pen to paper. This thesis examines the epistolary exchanges of Mary, Queen of Scots. As with many other members of the nobility during the early modern period, letters were a substantial part of Mary's life. Mary had a complex network of relationships with other European rulers and members of the nobility during her reign, with familial and religious ties to many rulers. Her letters were more than a maintenance of her domestic and foreign networks. Letters were also tools for self-presentation, the exercise of power, and courting favour. Letters written by female rulers, and specifically by queens regnant, in the early modern period are sources which can lead to a greater understanding of how these queens understood themselves in their roles as rulers within the political networks of both their country and of the continent in general. A queen regnant was a female monarch who inherited her political power and ruled independently from her husband. Women ruling on their own power are interesting historical cases as they show how female monarchs navigated the expression of their political power in a system where men ruled. In addition to these functions, letters often provide insight into the manner in which

\footnotetext{
${ }^{1}$ Mary Stuart, Queen of Scotland, "Letter Dated May 17, 1568: The Queen of Scots to Queen Elizabeth, From Workington," in Vol. 1 of Letters of Mary Queen of Scots, ed. Agnes Strickland (London: Henry Colburn, 1842), 43.
} 
female rulers wished to present themselves to the recipients of their letters. Letters could also serve as an outward or cathartic expression of emotion to an audience.

The first examines letters written by Mary from September to December 1565 when she was reigning in Scotland. At this point in her life Mary was exercising her political power as sovereign of Scotland. The letters deal with the kidnapping of one of her subjects by an English lord and raids from England across the Scottish border. The letters reflect how Mary dealt with international conflict when she was queen in her writing, to Elizabeth and diplomats. The second chapter analyses letters written from May to July 1568, in the months just after Mary had fled to England following her forced abdication. The letters in this chapter focus on Mary drawing on ties of kinship and rank, as well as appeals to justice in an effort to gain support for a return to her throne. During this period Mary had little political power as she has abdicated, but she still used her letters as a method of diplomacy and as a tool to convince others of her cause. The third chapter focusses on Mary's writings during the time of the investigation into the Casket Letters. The letters and statement from this chapter were written between October of 1568 and January of 1569 . Her letters focus on her attempts to ensure the Casket Inquiry ended in her favour. Her statement, written to be read on her behalf in front of the judges of the inquiry, was intended to show her commitment not to reaffirm her forced abdication. The writings show Mary's rhetorical flexibility as her strategies vary widely based on her audience and the format of the work.

Study of the letters shows that Mary was an accomplished rhetorician and could draw on her education, epistolary traditions and notions of gendered language and relationships in order to support her diplomatic enterprises. Analysis of these letters will 
show how she used the genre of the letter for a variety of different purposes depending on the recipient and the circumstance. An examination of Mary's letters, the conventions associated with the form during the period will be considered, including places wherein the author has deviated from these conventions for a specific purpose. The rhetoric used by Mary will also be examined in light of contemporary literary conventions and traditions in conjunction with her humanist education. This thesis is inherently interdisciplinary as it combines aspects of literary and historical analysis in order to examine these letters in the context of the early modern period.

She wrote the passage above to her cousin whom she had never met, the queen in whose country she believed she would find refuge. Mary Stuart, Queen of Scots, Dowager Queen of France, spent her entire life believing that she was born to rule. Even after her forced abdication of the Scottish throne a year previously, she still signed her letter Mary R: Mary Regina, Mary the queen. Mary was one of the first sovereign queens in Britain. Though she became queen when she was just days old, her cousins Mary Tudor and Elizabeth I both ascended their thrones before she became of age and assumed control of her country. Mary often found herself in conflict due not only to her position as a queen ruling in her own right but also as a result of her staunch Catholic beliefs, out of place in Protestant Scotland. When she fled to England she was embroiled in further strife as her claim to the English throne meant she was perceived as a threat to the reign of Elizabeth.

\section{Literature Review}

Mary was often the centre of conflict during her life. When she arrived in Scotland in 1560 following the death of her first husband, the Catholic queen was faced 
with a nobility that had mostly converted to a form of Presbyterianism. Tensions eventually began to mount against Mary, especially in the light of the murder of her second husband, Robert Darnley, and accusations of adultery with her third husband, the Earl of Bothwell. Eventually Mary was captured and imprisoned by her own nobles. Mary escaped and fled to England where she hoped her cousin, Elizabeth, would help her return to her throne. She instead became a prisoner in England as she was viewed as a threat to the reign of Elizabeth. Eventually Mary was implicated in the Babington Plot, a plan to assassinate Elizabeth, and was tried and eventually executed for treason in 1587. A significant amount of scholarly energy has been poured into study of Mary Queen of Scots in the centuries since her death. Like many monarchs, her life has been examined by biographers and has been the subject of monographs. Mary's rule ended in a forced abdication in favour of her son, imprisonment and execution. Her life was thus rife with narrative interest for historians. Her position as one of the few female sovereigns during the early modern period has made the history of her reign a valuable area of analysis for those interested in women's history and women's exercise of political power. Mary was also viewed as a martyr for the Catholic religion for many years as she had been driven from her throne by her Protestant nobles and executed for treason under Elizabeth. These circumstances meant that Mary's life was also scrutinized by religious writers. In the mid-nineteenth century, Agnes Strickland dedicated five volumes of her eight-volume work, Lives of the Queens of Scotland and English Princesses Connected with the Regal Succession of Great Britain (1851-1859) to a biography of Mary. Strickland also edited and translated a selection of Mary's letters into a two-volume collection, the first of which was published in 1842 and the second the following year. 
One of the most significant biographical works from recent years has been John Guy's Queen of Scots: The True Life of Mary Stuart. Guy has also published works on the Tudor rulers in England as well as other members of the English court. He also conducted the most complete modern investigation of the Casket Letters, the subject of the third chapter of this thesis, during the course of research for his work on Mary.

The general historical record presents Mary as a failure as a queen. The trope of 'success or failure' is one often displayed in English historiography. Assessments of Mary's status as 'failure' is supported by modern works such as Jenny Wormald's Mary Queen of Scots, A Study in Failure and Kristen Post Walton's Catholic Queen, Protestant Patriarchy: Mary Queen of Scots and the Politics of Gender and Religion. Guy and other historians like Retha Warnicke see Mary as a ruler who was ultimately unable to shape events to her will in the later part of her life. Other scholars have re-assessed Mary as a ruler. Alexandra Nancy Johnson's very recent work is a good example of efforts by scholars to highlight the ways in which Mary balanced her own interests with those of her enemies during her personal reign, granting nuance to her reign. ${ }^{2}$ Retha Warnicke argues that reports of Mary's proficiency in Privy Council meetings have not been taken seriously enough by both Wormald and Guy. ${ }^{3}$ Some historians have attributed the issues in Mary's reign to the fact that she did not regularly attend council meetings during her reign but when comparing her records to that of her son James when he was about her age the attendances are relatively similar and James was widely regarded as competent. ${ }^{4}$

\footnotetext{
${ }^{2}$ Alexandra Nancy Johnson, "Mary Stuart and Her Rebels-Turned-Privy Councillors: Performance of the Ritual of Counsel," in Queenship and Counsel in Early Modern Europe, eds. H. Matheson-Pollock, J. Paul, C. Fletcher (New York: Palgrave Macmillan, 2018), 161.

${ }^{3}$ Retha M. Warnicke, Mary Queen of Scots (New York: Routledge, 2006), 92.

${ }^{4}$ Warnicke, Mary Queen of Scots, 89.
} 
Mary was also the victim of propaganda in her own time, where she was presented both as a murderer and an adulteress, crimes of which modern historians have largely exonerated her. When Mary was imprisoned in Edinburgh by her own nobles an image of Mary as a mermaid, which was considered a symbol of prostitution, appeared on the Mercat Cross of Edinburgh, spreading the idea that she was sexually deviant. ${ }^{5}$ Cathy Shrank argues that propaganda against Mary began as vitriolic attacks on her character in the years following the murder of Robert Darnley but that during her imprisonment in England, it became more politically charged. ${ }^{6}$ Scholars generally agree propaganda against Mary was spread largely as a way to discredit her and those who remained loyal to her following her forced abdication and later, during the Marian civil war.

The analysis of the letters in this thesis, however, is not concerned with ideas of success or failure nor with contemporary representations of Mary. Mary’s correspondence reveals insight into the ways in which she managed diplomacy through rhetoric for the duration of her reign and imprisonment. This thesis echoes the work of those scholars who have chosen to focus on Mary's writing, not to assess her triumphs and defeats and issue judgement, but rather to assess the manner in which she governed and how she responded to complex issues of religion, gender and power dynamics.

Mary Stewart's rule as an example of “queenship studies” has also been underexamined. Palgrave Macmillan has published a series entitled Queenship and

\footnotetext{
${ }^{5}$ Kristen Post Walton, Catholic Queen, Protestant Patriarchy: Mary, Queen of Scots, and the Politics of Gender and Religion (New York: Palgrave Macmillan, 2007), 145.

${ }^{6}$ Cathy Shrank, “'This fatall Medea,' 'this Clytemnestra': Reading and the Detection of Mary Queen of Scots," The Huntington Library Quarterly 73, no. 3 (2010): 524.
} 
Power. ${ }^{7}$ Some volumes focus on queenship in literature, myth and modern media. While some contributions analyze periods outside the early modern, there are a number of volumes that focus on women's writing. Elizabeth I in Writing is perhaps the best example of this focus in the series, with chapters dedicated to the queen's translations of established works as well as to her prayers, poetry and correspondence. Also, in the series is Queenship and Counsel in Early Modern Europe, which includes Johnson's chapter on Mary and her counsellors discussed above. Mary Stuart also features significantly in Rayne Allinson's book, A Monarchy of Letters: Royal Correspondence and English Diplomacy in the Reign of Elizabeth I, in which a chapter is dedicated to the correspondence between the two queens. Allinson's work focusses on the epistolary diplomacy between Elizabeth and Mary and how both women used the sending and receiving of letters as performance, as well as the similarities and differences in the rhetoric the two queens used. In Queenship in Early Modern Europe, Charles Beem makes Mary the focus of queenship studies. The progress of Mary's status as a queen regnant in minority, then a queen consort of Francis II and then sovereign of Scotland, is used as a point of comparison to other European queens who only held one or two of

\footnotetext{
${ }^{7}$ The series currently contains sixty-five books, and while Mary occasionally is addressed in a chapter, none of the books have been dedicated entirely to her. Eight of these books are entirely dedicated to Elizabeth I, and she is heavily discussed in many others. For more in the series on Elizabeth I see Carlo M. Bajetta, Elizabeth I's Italian Letters (New York: Palgrave Macmillan, 2017); Anna Reihl, The Face of Queenship (New York: Palgrave Macmillan, 2010) and Linda Shenk, Learned Queen (New York: Palgrave Macmillan, 2010). These examples further show a focus on Elizabeth's writing and self-presentation. For Palgrave Macmillan's books on Mary Stuart, all published outside the Queenship and Power series, see Kristen Post Walton, Catholic Queen, Protestant Patriarchy: Mary Queen of Scots and the Politics of Gender and Religion (New York: Palgrave Macmillan, 2007); Alexander Wilkinson, Mary Queen of Scots and French Public Opinion, 1542-1600 (New York: Palgrave Macmillan, 2004) and Sarah Dunnigan, Eros and Poetry at the Courts of Mary Queen of Scots and James VI (New York: Palgrave Macmillan, 2002).
} 
these roles. ${ }^{8}$ The Palgrave Macmillan series and Beem's book not only shows a current interest in gender and power but also in women's writing. What it also reveals, however, is that Mary Stuart has still been largely unexamined in these areas. While Mary's life has been examined extensively in biographies, study of her writing and reign are far outweighed by focus on Elizabeth I.

One set of texts that have been significantly examined in their relation to Mary's life are the Casket Letters. These letters, presented as evidence in an attempt to prove the queen culpable in the death of her second husband, Lord Robert Darnley, have long been the focus of Mary's textual production. The irony here is that through modern examinations of the letters, these documents are widely considered by scholars to be significantly doctored. The letters have some sections that were written by the queen, but they are often spliced together with other fragments written at a different time or with outright forged passages. ${ }^{9}$ Thus the focus on Mary's wholly genuine letters has been largely obscured by a focus on a set of documents widely considered to be controversial and not wholly authentic.

Despite interest in the Casket Letters, Mary's letters have remained largely unexamined. By contrast, the letters of her contemporaries, specifically Elizabeth I and Catherine de' Medici, are subjects of entire volumes. Biographers often reference Mary's letters and poetry as sources for her life and use them to support or refute authors' ideas about her character and to produce an accurate timeline of events. The letters are not

\footnotetext{
${ }^{8}$ Charles Beem, Queenship in Early Modern Europe (London: Red Globe Press, 2020), 78.

${ }^{9}$ For the most significant analysis of the casket letters, see J. Guy, Queen of Scots: The True Life of Mary Stuart, 384-423 and A. E. MacRobert, Mary, Queen of Scots and the Casket Letters (London: Bloomsbury, 2002). The assessment of the degree to which the letters were forged and altered will be further examined in chapter three.
} 
often studied as works of diplomacy, rhetoric or self-presentation, reflecting on Mary as a ruler and her participation in existing power structures while establishing a voice of her own.

In recent decades there has been more interest not only in Mary's writings but also her needlework and embroidery as new 'texts'. Susan Frye and Nicole LaBouff have written about Mary's embroidery, completed while she was imprisoned in England, as a source for examining modes of power. Frye asserts that the embroidery of many noble women, including Mary, was used to display their social and political alliances as a way to assert themselves in a manner that did not directly counter contemporary notions of feminine silence and modesty. ${ }^{10}$ Nicole LaBouff makes the argument that Mary's embroidery was more than a reflection of her political views, as had previously asserted, but also served as a way to fuse male scholarly information management practices such as scientific collection and commonplace books with the feminine work of embroidery. ${ }^{11}$ Mary's poetry has also become a subject of analysis. Joy Currie argues that much of Mary's poetry written while she was imprisoned in England focussed on presenting herself as a suffering and pious queen and someone deserving of sympathy. ${ }^{12}$ Her poetry has been presented in edited and translated volumes, the most prominent being Robin

\footnotetext{
${ }^{10}$ Susan Frye, "Sewing Connections: Elizabeth Tudor, Mary Stuart, Elizabeth Talbot and Seventeenth-Century Anonymous Needleworkers," in Maids and Mistresses, Cousins and Queens: Women's Alliances in Early Modern England, eds. S. Frye, K. Robertson (Oxford: Oxford University Press, 1999), 166.

${ }^{11}$ Nicole LaBouff, "Embroidery and Information Management: The Needlework of Mary Queen of Scots and Bess of Hardwick Reconsidered," Huntington Library Quarterly, 83, no. 3 (August 2018): 319 .

${ }^{12}$ Joy Currie, "Mary Queen of Scots as Suffering Woman: Representations by Mary Stuart and William Wordsworth," in "High and Mighty Queens" of early Modern England: Realities and Representations, eds. C. Levin, J. Eldridge Carney, D. Barrett-Graves (New York: Palgrave Macmillan, 2003), 190.
} 
Bell's edition of 1992. Bell makes no overarching argument about the nature of Mary's poetry but notes her fondness for wordplay and also the vulnerability and intense emotion reflected in her poetry. Rosalind Smith has examined Mary's poetry and other marginalia in her fifteenth-century manuscript Book of Hours, arguing that they supported the argument that marginalia was not only reflective of private piety but was also a form of goal-oriented political writing. ${ }^{13}$ These studies ultimately show that activities traditionally performed by women could have political and academic purposes and the idea of the political cannot be restricted to traditional structures of power like parliaments and councils. Expanding the political sphere means that women who did not hold positions of traditional political power, including Mary after her abdication, could still participate in political activities.

We now turn to the existing scholarship on Mary's letters specifically. Cristy Beemer and Rayne Allinson seem to be the only modern scholars to write about Mary's use of letters as a tool of diplomacy or self-presentation. Beemer argues that Mary’s letters to Elizabeth before her execution made use of similar rhetorical techniques used by Elizabeth herself when she was imprisoned in the tower by her sister Mary Tudor. Beemer focuses on the fact that both women took advantage of the moment in which they were writing in their requests for mercy, using appeals to shared kinship, a male history of kingship and the use of the letter as performance. ${ }^{14}$ Allinson argues that the epistolary relationship between Elizabeth I and Mary was an attempt by the older and more

\footnotetext{
${ }^{13}$ Rosalind Smith, "'Le pouvoir de faire dire': Marginalia in Mary Queen of Scots' Book of Hours," in Material Culture of Early Modern Women's Writing, eds. P. Pender and R. Smith (New York: Palgrave Macmillian, 2014), 56.

${ }^{14}$ Cristy Beemer, "God Save the Queen: Kairos and the Mercy Letters of Elizabeth I and Mary, Queen of Scots," Rhetoric Review 35, no. 2 (2016), 76.
} 
experienced Elizabeth to influence the younger Mary, who often turned to her for advice, and Scottish politics more generally. As Mary began to act contrary to Elizabeth's advice, the English queen began to mistrust her Scottish counterpart. ${ }^{15}$ Allinson also notes that in the later years of her imprisonment in England, Elizabeth stopped replying to Mary's letters. Mary continued to write, however, and Allinson argues that these later letters serve more as records for posterity as she was struggling to understand her purpose while imprisoned and not able to exercise the diplomatic measures of her letters as she had no country to rule. ${ }^{16}$ John Guy relies strongly on Mary's letters to show her responses to significant events in her personal reign. For example, her letter to Elizabeth, offering an explanation of her reasons for marrying Bothwell is used as a source for Mary's version of the events leading up to the marriage. ${ }^{17}$ In most cases, however, Guy favours reports by ambassadors such as Thomas Randolph over examining Mary's own letters. Both Guy and Warnicke favour Labanoff's collection when they make reference to Mary's letters, whereas this thesis focusses more on Strickland's edition. While neither edition is considered scholarly by modern standards and both correct antiquated spellings without notation, Labanoff's edition does present manuscript numbers for the original documents while Strickland's does not. ${ }^{18}$ The editions do not contain any overlap in the letters they present, with Labanoff making note of that fact in the front matter of his edition. Even with these studies, most of Mary's letters remain unexamined. A focus on these writings presents an opportunity to examine the diplomatic and rhetorical techniques of the period

\footnotetext{
${ }^{15}$ Rayne Allinson, A Monarchy of Letters: Royal Correspondence and English Diplomacy in the Reign of Elizabeth I (New York: Palgrave Macmillan, 2012), 91.

${ }^{16}$ Allinson, A Monarchy of Letters, 89.

${ }^{17}$ Guy, Queen of Scots, 342.

${ }^{18}$ Neither edition notes when a letter has been translated from another language nor do they indicate crossings out, other signs of revision to the copy or damage to the original manuscript.
} 
as they pertain to gender and religion. These written sources provide a deeper insight into Mary's personal reign. This thesis will build on these understandings of Mary's letters as political tools, while expanding to letters outside of those written to Elizabeth to show how Mary used bonds of kinship and shared religion with other rulers, as well as calls to duty and friendship with diplomats. A focus on using letters as sources for the lives of women is not unique to this thesis however.

\section{Examining Women's Writing}

This thesis participates in a wider turn in early modern women's history to turn to the writing of women themselves as the most important source for women's lives. With the solidification of women's history as its own discipline in the 1970s, narratives of women were told through sources that were created by men. ${ }^{19}$ Sources like parliamentary and court records were used to tell the stories of women as these were often some of the only written sources where women appeared. The Return of Martin Guerre, by Natalie Zemon Davis, is a good example of the manner in which women's historians of the early modern period are often forced to rely on these types of sources. In examining the lives of peasants who wrote little of themselves, Davis often had to rely on court cases that pertained to marriage in her examination of women. ${ }^{20}$ With noble women the temptation is often the same. Official records, almost exclusively created by men, are the best

\footnotetext{
${ }^{19}$ Prominent examples of this phenomenon exist in Judith Walkowitz and Daniel Walkowitz, "'We Are Not Beasts of the Field': Prostitution and the Poor in Plymouth and Southampton under the Contagious Diseases Acts," Feminist Studies 1, no. 3 (1973): 73-106. The article is widely considered one of the first articles of what was then called 'feminist history' in the 1970s, a discipline which would evolve into the discipline of the history of women and gender which is more recognizable today. The article relies almost entirely on court records and records from infectious disease hospitals for the presentation of working women's history. The only records of women speaking for themselves are filtered through reports of male government officials. ${ }^{20}$ Natalie Zemon Davis, The Return of Martin Guerre (Cambridge: Harvard University Press, 1983), 3.
} 
sources for women's lives in the early modern period. A new turn to a focus on women's history, told through their own created works, literary and material, offers a chance to examine history through the lived experiences of women, rather than simply what is said about them by men. ${ }^{21}$

Over the past two decades, new editions of women's writing from the early modern period have been published to wide success. Chief among these are the scholarly editions of the writings of Elizabeth I and Katherine Parr, which were published by the University of Chicago Press in 2000 and 2011 respectively. In the preface of Elizabeth I: Collected Works, the editors note that while biographers had previously noted Elizabeth's exemplary education there had been little more than "cursory attention" paid to the content of her writing, that her writing was often only analyzed through a political lens, and that the scholarly edition aimed to support a more holistic examination of her writing. ${ }^{22}$ These editions contain selections of letters, speeches, poetry, prayers and other writings. Currently there is no such edition for Mary's written works outside of her poetry and the limitations that the editors identified with the study of Elizabeth's writing still holds true for that of Mary. Alison Wiggins at the University of Glasgow, in collaboration with the Women's Early Modern Letters Online (WEMLO) is embarking upon an effort to create a database of Mary's letters specifically. The project was intended to be launched in 2020 but has since been delayed. The last editions of Mary

\footnotetext{
${ }^{21}$ The focus on women's lived experience in history is also connected to the 'Material Turn', wherein material sources are being understood to hold equally significant insights into historical narratives as textual sources. The respect for material sources has also opened up the field of women's history as often in earlier time periods, women's contribution to material culture far outweighed their textual contributions.

22 "Preface," in Elizabeth I: Collected Works, eds. L. S. Marcus, J. Mueller and M. B. Rose (Chicago: University of Chicago Press, 2002), xi.
} 
Stuart's letters were published in the mid-nineteenth century by Agnes Strickland and Alexander Labanoff. In addition to such academic editions of women's writing, there has been one journal created to focus exclusively on the interdisciplinary study of women in the early modern period. While Early Modern Women: An Interdisciplinary Journal, founded in 2006, does not focus solely on women's writing, there is still a focus on the ways in which women present their own histories in a variety of formats including art and material culture in addition to writing.

Letter-writing as a genre has been the subject of study for many scholars of the early modern period. As this form of writing was very common and integral for the function of commerce, diplomacy and familial relationships, especially among the nobility and merchant classes, letters provide rich sources to historians studying a wide variety of topics. Letters were often used as sources for the course of events and proof of historical occurrences. In an edited volume, Toon Van Houdt and Jan Papy argue that letters have more to offer than insight into the topics they discuss or works of exemplary prose. They posit that the letters use rhetoric as a means of self-presentation, in addition to the role of the communication of information. ${ }^{23}$ A prominent example of letters moving beyond the role of records of historical 'fact' and taking on a different role as a source in British history comes from the Paston Letters, one of the largest repositories of English private correspondence from the fifteenth century. In his introduction to the Paston Letters, Norman Davis describes the letters as primarily a collection of family

\footnotetext{
${ }^{23}$ Toon Van Houdt and Jan Papy, "Introduction," in Self Presentation and Social Identification: The Rhetorics and Pragmatics of Letter Writing in Early Modern Times, eds. T. Van Houdt, J. Papy, G. Tournoy, C. Matheeussen (Leuven: Leuven University Press, 2002), 3.
} 
records and therefore a source for social history. ${ }^{24}$ In the decades since the publication of the collection, multiple authors have used the Paston Letters as a source for discussing more than historical timelines and events but as an opportunity for insight into a wide variety of topics. Using the letters as a significant source, Joel Rosenthal has completed a study on lay women's piety, using Margaret Paston as a focus. ${ }^{25}$ Alexander Bergs has even used the letters as a source for the study of both sociolinguistics and social networks during the fifteenth century. ${ }^{26}$ The collected correspondence of the Pastons is shown to have meaning beyond simply tracing the history of one particular family, and can provide many and varied insights into late-medieval England.

A new focus on female authorship and agency in the early modern period is growing. James Daybell focuses on women's letters as an important source for the early modern period. In Women Letter-Writers in Tudor England, he takes women's letters as a main source in the examination of gender in the early modern world. ${ }^{27}$ Daybell argues that noble and middle-class women's letters of the period are not restricted to the private sphere of the household and show both political awareness and action as well as a participation in humanist principles of friendship and favour and contemporary epistolary conventions. Letters by women in this period negotiate fluid boundaries of public and

\footnotetext{
${ }^{24}$ Norman Davis, "Introduction," in Paston Letters and Papers of the Fifteenth Century, vol. 1, ed. N. Davis (London, Oxford University Press, 1971), xxi.

${ }^{25}$ See Joel Rosenthal, Margaret Paston's Piety (New York: Palgrave Macmillian, 2010).

${ }^{26}$ See Alexander Bergs, Social Networks and Historical Sociolinguistics : Studies in Morphosyntactic Variation in the Paston Letters (Berlin: Mouton de Gruyter, 2005). ${ }^{27}$ For work on women's letters of the period outside of Britain see Meredith Ray, Writing gender in women's letter collections of the Italian Renaissance (Toronto: University of Toronto Press: 2009) and Carol Pal, Republic of Women: Rethinking the Republic of Letters in the Seventeenth Century (Cambridge: Cambridge University Press, 2012).
} 
private, political and domestic. ${ }^{28}$ Daybell has also written the first full length work which discusses the material letter in early modern England. ${ }^{29}$ The book combines textual analysis with material culture in the analysis of letters and their value during the period. This thesis builds upon Daybell's works on the way women's letters blend the political and private. In addition, I build on Daybell in using gender as an important lens for discussing epistolary rhetoric. He argues that women use gendered language in letters in order to achieve political goals while still espousing traditionally feminine qualities, a line which Mary walks very finely, as will be examined in chapter three. ${ }^{30}$

This thesis fills a void in the examination of Mary's body of letters. My examination of the way in which Mary used letters as a tool for diplomacy and selfexpression provides insight not only into Mary's reign and imprisonment but also into the way powerful women generally expressed themselves in epistolary form.

\section{Rhetoric and Education}

This thesis focuses on how Mary used letters as a tool of diplomacy and the development of relationships between members of the nobility and their agents. Letters were, of course, a method of communicating information but they were also an avenue

\footnotetext{
${ }^{28}$ James Daybell, Women letter-writers in Tudor England (Oxford: Oxford University Press, 2006), 6. Daybell is also one of the co-directors of Women's Early Modern Letters Online (WEMLO), an online database for women's letters from the period. This database was created to provide easier access to women's letters from the period and encourage study of these sources. For reports on the complications and challenges associated with WEMLO specifically, and its larger aims see Kim McLean-Fiander and James Daybell, "New Directions in early modern women's letters: WEMLO's challenges and possibilities," in Women and Epistolary Agency in Early Modern Culture, 1450-1690, eds J. Daybell and A. Gordon, 223-238. New York: Routledge, 2016.

${ }^{29}$ James Daybell, The Material Letter in Early Modern England: Manuscript Letters and the Culture and Practices of Letter-Writing, 1512-1635 (New York: Palgrave MacMillan, 2012), 10.

${ }^{30}$ James Daybell, "Women's letters of recommendation and the rhetoric of friendship in sixteenth-century England," in Rhetoric, Women and Politics in Early Modern England, eds. J. Richards, A. Thorne (London: Routledge, 2006), 179.
} 
for diplomacy and rhetoric. Letters as a form of writing became widely important during the Renaissance due to increased literacy and the rise of robust postal networks. During the period, many handbooks for letter-writing were published in vernacular languages. Epistolary forms became more important in education for students who studied beyond the primary level. Classical epistolary rhetoric was an essential component of schooling. ${ }^{31}$ While higher levels of education were often limited for a majority of women in early modern Britain, royal women were almost always an exception. Education was necessary for women to perform the duties of court. Such an education was also a symbol of status for women. Humanist education became essential for royal children in the early modern period.

Mary and Elizabeth shared a similar program of education in their formative years. Elizabeth's humanist education has been much studied, especially in reference to her writings. She was educated primarily by Roger Ascham and William Grindal, who were both students of John Cheke. Mary's education was almost identical to that of her betrothed, Francis the dauphin of France, which she received in France at the court of Henri II. She was not the only girl at court to receive a humanist education. Female members of the French nobility also participated in this educational programme. ${ }^{32}$ For Mary, her uncle, the Cardinal of Lorraine, Catherine de' Medici and Diane de Poitiers supervised her education with the latter in charge of appointing her tutors as well as those for the other royal children. ${ }^{33}$ The focus on a humanist education, which certainly included rhetoric, was unique for even royal women. James Daybell notes that when an

\footnotetext{
${ }^{31}$ Daybell, The Material Letter in Early Modern England, 53.

${ }^{32}$ John Guy, Queen of Scots: The True Life of Mary Stuart (New York: Mariner, 2005), 68.

${ }^{33}$ Guy, Queen of Scots, 69.
} 
education program was being decided for Mary Tudor, rhetoric was largely considered to be insignificant for the education of a princess. ${ }^{34}$ Naturally the two Marys were born into different circumstances as Mary Tudor was a princess whereas Mary Stuart was an anointed queen, but this example displays the gendered nature of rhetorical education even from a few decades before Mary was born. Ultimately there was conflict over whether rhetoric was an appropriate or useful topic in girl's education during the period, with writers like Richard Mulcaster suggesting in 1581 that it should be included. ${ }^{35}$ Despite the debate, some royal women, Mary Stuart and Elizabeth among them, received a humanist education that was similar to their male counterparts.

Both letter-writing and rhetoric had a significant place in Mary's education from a young age. The composition of letters was often used as a tool in teaching students how to learn Latin as well as rhetoric as it was widely considered to be one of the easier forms to master. Much of Mary's early writings were Latin letters that were 'addressed' to the princesses she studied with, her betrothed and her de Guise uncles, but these letters were merely exercises and the recipients likely never read them. ${ }^{36}$ John Guy reports that these letters, along with other of Mary's schoolroom exercises, reflected little of herself. One of the young queen's exercise books survives from her education at the French court which contains her Latin epistles and was recorded in a catalogue of her library after her abdication. ${ }^{37}$ Mary's letters which will be examined in this thesis necessarily reflect much more of the mind of the queen than her childhood writing. Though some of Mary's

\footnotetext{
${ }^{34}$ Daybell, "Women's letters of recommendation" 172.

${ }^{35}$ Daybell, "Women's letters of recommendation," 172.

${ }^{36}$ Guy, Queen of Scots, 70.

${ }^{37}$ John Durkan, "The Library of Mary, Queen of Scots," in Mary Stuart, Queen in Three Kingdoms, ed. M. Lynch, (Oxford: Basil Blackwell, 1988), 75.
} 
language and rhetoric in her letters is rooted in convention, she used the foundation of her humanist education to express herself as queen regnant.

Rhetoric, though it was often practiced through the more contemporary form of letter-writing, was a subject which, during the period, had its basis in classical texts. However, as in the case of Elizabeth, Mary's tutors were humanists who were adapting classical ideas about rhetoric into treatises for contemporary use. One of Mary's tutors, Antoine Fouquelin, wrote a treatise on rhetoric in French which he dedicated to the queen and praised her potential as a pupil in his dedication. ${ }^{38}$ Among the classical texts included in Mary's education was Aristotle's Rhetoric, considered to be one of the most authoritative treatises on the subject. ${ }^{39}$ One of the most famous components of Aristotle's discussion of rhetoric was the components of proof. According to Aristotle proof could either be artificial or inartificial. The latter referred to proof that came from laws or testimonies, meaning that it had a basis in something other than the author's word. ${ }^{40}$ Artificial proof can further be divided into ethos, or establishing the author's character and credibility; pathos, attempting to influence the emotion of the audience; and logos, the presentation of a rational argument. ${ }^{41}$ These concepts were essential components of rhetorical education, not only in the early modern period but also in the following centuries. Other texts were prominent as significant for rhetorical development, especially in letters. Erasmus wrote several influential texts on letters that were well received during the period. ${ }^{42}$ Though there is no direct reference to these works in Mary's

\footnotetext{
${ }^{38}$ Guy, Queen of Scots, 69.

${ }^{39}$ Guy, Queen of Scots, 68.

${ }^{40}$ Richard A. Lanham, A Handlist of Rhetorical Terms: A Guide for Students of English

Literature (Berkley: University of California Press, 1969), 122-123.

${ }^{41}$ Lanham, A Handlist of Rhetorical Terms, 123.

${ }^{42}$ Daybell, "Women's letters of recommendation, 175.
} 
schooling, despite the fact that she showed a great enjoyment of Erasmus' In Praise of Folly, there is no doubt her humanist tutors were influenced by his work on letters. ${ }^{43} \mathrm{Her}$ humanist education clearly had an influence on the way Mary wrote letters, but her education and young life also included influences beyond her formal tutors who would influence the texts she produced.

Formal treatises were not the only influence on Mary's writing. Poetry also had an impact. Mary had a deep appreciation for French poetry and was reported to enjoy studying contemporary literary works far more than the classics. She studied poetry under Pierre de Ronsard, who was a member of the Pléiade circle of poets. The members of the Pléiade were determined to take the advice of Dante to use simple vernacular language to ensure that their poetry and the emotion contained within it would be accessible to all those who spoke French. ${ }^{44}$ Mary deeply appreciated these ideas and became a patron of Ronsard when she was just fourteen, providing financial assistance in the publication of his first volume of poetry. The poets of the Pléiade continued to be close friends of Mary and often sent her verses, even when she had returned to Scotland as queen. ${ }^{45}$ Connections have been made by Robin Bell between Mary's poetry and the group, but there has been little examination into the way Mary's admiration of their values were reflected in other genres of writing. Mary's letters, as they will be examined in this thesis, often do not shy away from expressions of emotion. When she was angry or frustrated, her recipient would know, no matter their rank. Mary prioritized clear language in her letters to communicate plainly, even where emotion was concerned.

${ }^{43}$ Guy, Queen of Scots, 70.

${ }^{44}$ Guy, Queen of Scots, 72.

${ }^{45}$ Guy, Queen of Scots, 73. 
Despite royal women generally receiving the same education as male counterparts, rhetoric and letters remained gendered. James Daybell's study of high-born women's letters of recommendation serves as a good example of the manner in which women used specific contemporary cultural rhetoric based on the ties of female friendship in addition to drawing on their humanist rhetorical education. For example, women often used the Senecan language of alliance and friendship in order to assist in making requests for their friends or family to powerful people. The use of Senecan language, Daybell argues, was not solely due to an education in the classics, but also because this type of language permeated the society in which they lived, especially in the political sphere. ${ }^{46}$ Mary had a very firm grasp on the use of this language in her diplomatic missives, constantly making reference to her friendships and ties of kinship with important figures in her network of diplomacy.

\section{Epistolary Exchange and Convention}

Though the study of the genre of the letter has been previously explored in this introduction, it is necessary to explain how the form was used by people of the period. Letters were multidimensional documents and although some were predecessors of the personal and private communication between people we understand them to be today, they also served other purposes. Letters were often public documents, ones that were expected to be read not only by the recipient but that were often circulated to multiple readers in both public and private spaces. The famous "Republic of Letters" of the

\footnotetext{
${ }^{46}$ Daybell, "Women's letters of recommendation," 174.
} 
Enlightenment as well as widely publicized collections of letters of intellectuals of the period show the form as more than private. $^{47}$

In England, during the early modern period, letter writing became common practice for a substantial amount of the population, especially with the increase in literacy. During the sixteenth century, letter writing was commonly taught at grammar schools attended by young boys. Though girls commonly did not attend formalized education they were also encouraged to learn the form as it was considered an important social skill. ${ }^{48}$ Epistolary instruction was often highly formalized and was usually taught in Latin. ${ }^{49}$ The vernacular letter was also important during the period and many officials wrote in English. Published letter writing manuals written in English which gave instructions and examples for emulation became widely circulated starting in the early part of the sixteenth century. ${ }^{50}$ The catalogue of Mary's library, completed during the early years of James VI's reign, shows that the queen owned a printed volume of a famous anthology of letter examples. ${ }^{51}$

James Daybell has challenged the idea that women's letters did not engage in the public sphere. Daybell, using the example of the correspondence of Bess of Hardwick, attempted to counter the traditional idea that women's letters were confined to the domestic sphere and argues that they were instead often explicitly political. ${ }^{52}$ Of course

\footnotetext{
${ }^{47}$ Editions of Erasmus' letters were particularly popular in the sixteenth century and the humanist wrote thousands of letters during his life. The University of Toronto Press is publishing The Correspondence of Erasmus with volume twenty-one being slated for release in August of 2021.

${ }^{48}$ Daybell, The Material Letter in Early Modern England, 53.

${ }^{49}$ Daybell, The Material Letter in Early Modern England, 54.

${ }^{50}$ Daybell, The Material Letter in Early Modern England, 20.

${ }^{51}$ Durkan, "The Library of Mary, Queen of Scots" 80. Durkan does not provide the title of the anthology.

52 James Daybell, Women letter-writers in Tudor England, 3.
} 
Mary's participation in the public sphere was far less restricted than other women of the period as she was the reigning monarch and thus her occupation of political space was a necessity rather than an option. Even so, it is significant to understand that she was not unique among women in using letters as a political tool. Noble women used letters in order to mediate relationships of patronage, gather news and request advice. ${ }^{53}$ But to Daybell, letters can also be autobiographical in the sense that women wrote in a manner which presented a 'self' to their recipients. ${ }^{54}$ While the notion of Mary's letters being significant to a biographical narrative is not revolutionary, an approach to the letters as being works of self-presentation is relatively unexamined, as previously stated. Daybell succinctly states that letters have often been used as "straightforward depositories of historical fact," which is most often the way in which Mary's letters have previously been viewed. ${ }^{55}$

Using gender as a mode of analysis for early modern letters is complicated by the practices of letter-writing during the period. Early modern letters have an inherently collective authorship as scribes and secretaries were often used for committing a dictated letter to paper. This notion challenges the idea of a single author, wholly responsible for the creation of the work. ${ }^{56}$ As secretaries were almost exclusively male, this opens up complications to the use of gender in the analysis of letters. There is a further layering of gender in women's letters as often women were counselled by men in how to present

\footnotetext{
${ }^{53}$ Daybell, Women letter-writers in Tudor England, 4-5.

${ }^{54}$ Daybell, Women letter-writers in Tudor England, 7.

${ }^{55}$ Daybell, Women letter-writers in Tudor England, 61.

${ }^{56}$ Daybell, Women letter-writers in Tudor England, 61.
} 
themselves in the epistolary form. ${ }^{57}$ This complexity is far less prominent with royal women, sovereign queens specifically, as, though they did participate in collective authorship, they wrote on their own authority, which was the highest in a monarchical political organization. ${ }^{58}$ Indeed, one of the limitations of having no scholarly edition of Mary's work is that there is little indication in Strickland or Labanoff's editions where secretaries might have made alterations to copies, making it difficult to discern to what degree Mary's letters were a product of collective authorship.

Though letters served the important purpose of personal expression or maintenance of personal relationships, diplomacy was another main use of the epistolary form. Humanist education and rhetoric had significantly influenced the diplomatic processes of Italy early in the renaissance and this spread to the rest of Europe, including Britain. Correspondence as a tool of diplomacy was common practice, not only between rulers directly but also with diplomats acting as intermediaries. ${ }^{59}$ One of the primary, and perhaps most obvious, diplomatic functions of letters was that they served as a way to communicate information. Intelligence letters were primarily used as a method of communication between agents in a foreign country and either their sovereign or the person who was responsible for the diplomatic mission. ${ }^{60}$ But these letters were not only

\footnotetext{
${ }^{57}$ James Daybell and Andrew Gordon, "Living letters: Re-reading correspondence and women's letters," in Women and Epistolary Agency in Early Modern Culture, 1450-1690, eds. J. Daybell, A. Gordon (New York: Routledge, 2016), 2.

${ }^{58}$ Marcus, Mueller and Rose have made significant note in their collection of Elizabeth's works where Cecil made corrections or contributed significantly to the body of the letter. For a prominent example of this, see "Elizabeth to Philip II of Spain, September 30 1562", 112-115.

${ }^{59}$ Tracey Sowerby and Joanna Craigwood, "Introduction," in Cultures of Diplomacy and Literary Writing in the Early Modern World, ed. T. Sowerby, J. Craigwood (Oxford: Oxford University Press, 2019), 5.

${ }^{60}$ Robyn Adams, "A Most Secret Service: William Herle and the Circulation of Intelligence," in Diplomacy and Early Modern Culture, eds. R Adams, R. Cox (London: Palgrave Macmillan, 2010), 65 .
} 
reports of the goings on in a foreign country but could also serve as a method of securing favour for the agent abroad. William Herle, in his work for Francis Walsingham in Elizabeth's court both provided intelligence about Mary in a 1582 letter, but also asked for assistance with a debt. ${ }^{61}$ These interactions did not often involve the monarch directly as the person in charge of the diplomatic mission would usually provide their own report to their sovereign. Generally, letters between monarchs and diplomats were more focused on specific issues rather than a report of events. Generally, letters concerned the specific mission for which the diplomat was sent abroad. ${ }^{62}$ This specific focus is very clear in the letters written by Mary in chapter one. Often even letters directly between monarchs were mediated by a diplomatic agent. Letters between Mary and Elizabeth, while Mary was still reigning in Scotland, were often transferred between the two queens by Thomas Randolph, Elizabeth's agent in Scotland. Mary often opened letters from Elizabeth in front of Randolph and showed her pleasure at the contents. ${ }^{63}$ In addition, Mary expressed to Randolph that she wished her cousin would write more often to her but that she was extremely grateful for the letters she had already received ${ }^{64}$ Mary also made direct references to the diplomatic bearers of her letters in her writing, stating they had more information or even other letters to forward. Letters between monarchs exist in an interesting liminal space as each had their own networks of subjects operating in foreign countries and while the address was direct, agents and diplomats often served as important intermediaries.

\footnotetext{
${ }^{61}$ Adams, "A Most Secret Service," 67.

${ }^{62}$ Robyn Adams, "A Most Secret Service," 66.

${ }^{63}$ Rayne Allinson, A Monarchy of Letters, 77-78.

${ }^{64}$ Allinson, A Monarchy of Letters, 77.
} 
For women particularly, letters served the diplomatic purpose of maintaining relationships, both personal and political. There is a large body of letters which were written by noble women in order to support patronage relationships or ask for favour. In this case as well, letters were usually not to the monarch, but to important members of their counsel, often their secretary. William Cecil, Robert Cecil and Julius Caesar all received a significant number of letters from women seeking favour or thanking them for receipt thereof, showing the degree to which letters as a tool for women's political intervention was widely used and accepted ${ }^{65}$ But there were instances where women wrote to monarchs directly. Daybell provides the example of Penelope, Lady Rich, who wrote to James VI, Mary's son, as a way to assist her brother, the Earl of Essex, in pursuing a diplomatic relationship with the king. ${ }^{66}$ Though Mary's political power as queen meant that she was writing directly to other monarchs on a consistent basis, it was not unusual for noble women to do the same in order to participate in a diplomatic network. Letters were not only an important tool for self-expression but also for the maintenance of diplomatic relationships and were well recognized as one of the most acceptable formats for requesting favour, advice or assistance. Examination of Mary's letters not only will give insight into her diplomatic and personal relationships with her addressees but also her use of rhetoric to attain her specific goals.

\section{Thesis Structure}

Each of the three chapters of this thesis will focus on one particular period in Mary's life. Each of these sets of letters have specific goals for the rhetoric contained

\footnotetext{
${ }^{65}$ James Daybell, "Gender, Politics and Diplomacy: Women, News and Intelligence Networks in Elizabethan England," in Diplomacy and Early Modern Culture, eds. R Adams, R. Cox (London: Palgrave Macmillan, 2010), 104.

${ }^{66}$ James Daybell, “Gender, Politics and Diplomacy,” 106.
} 
within them and each chapter will show Mary's approach to attaining those specific goals. Chapter one focuses on English raids into Scotland and the imprisonment of the Earl of Bedford in the autumn of 1565. This chapter examines Mary's use of international networks to exercise her own political power. The chapter provides analyses of three letters written by Mary which have not been included in any published edition thus far which I transcribed from original manuscripts housed at the British Library. ${ }^{67}$ Two of these transcriptions are provided as an appendix in this thesis. The three letters originate from the Lansdowne Collection at the British Library and were digitized through the State Papers Online database. Chapter two is situated in the first months of Mary's imprisonment in England during the summer of 1568. This chapter examines Mary's discussion of the importance of rank, kinship and justice in her attempts to be brought before Elizabeth. It also considers her use of emotion as a tool of persuasion. Chapter three focuses on the beginning of the inquiry into the casket letters in the autumn of 1568 and the winter of 1569 . This chapter discusses Mary's attempts to assert her rights as a sovereign in prison, as well as her self-presentation as a suffering queen, both with the aim of swaying the inquiry in her favour. Through the examination of these letters which were created under different circumstances, this study will show Mary's rhetorical and literary flexibility to attain her goals, depending on her audience and circumstance.

\footnotetext{
${ }^{67}$ These original transcriptions were produced using images supplied by the British Library's Digitization Services.
} 


\section{Chapter One: Writing Diplomatic Relationships in Mary's Personal Reign}

The purpose of this chapter is to examine five letters written from September to December of 1565 during Mary’s personal reign in Scotland addressed to her own subjects, ambassadors and other rulers. The letters shed light on Mary's approach to foreign policy and diplomacy during the first four years of her personal reign. The chapter studies how Mary exercises power through her diplomatic correspondence. In addition, the letters show the difference between diplomacy concerned with specific business and a more general form of foreign relations intended to maintain alliances. The study of the letters displays Mary's diplomatic strategies and her careful use of orders and recommendations, self-presentation and epistolary conventions in order to exercise her power and attempt to defend her sovereignty at times when it was threatened. In diplomatic relations that were focussed on particular events, assertions of authority were tied to specific circumstances, while in diplomatic letters aimed to maintain alliances rhetorical self-presentation and reliance on ties of kin and religion were used. The turmoil in Scotland before and during her reign made it even more essential for Mary to assert her authority. Early in her personal reign, Mary faced challenges to her authority from her nobles, most of whom were staunch Protestants, as well as from other rulers, including Elizabeth, who sought to influence her decisions on marriage and policy.

The letters contained within this chapter can be divided for the purpose of analysis into two groups: letters to ambassadors and letters to fellow rulers. The letters to ambassadors, both foreign and domestic, revolve around more basic business. They provide instructions: issue requests, and discuss arrangements for travel. They revolve around the day-to-day operations of the diplomatic network. When writing to other rulers, 
the difference is clear, while there are requests made for support or friendship, there is an argument presented as to why those requests should be honoured by the recipient. When writing to other rulers, Mary justifies her own requests, which would be unnecessary to do with those not of the ruling class. In addition, these letters do not focus on simple operations but rather introduce broader ideas about the nature of the relationships between the sovereigns and their countries.

The letters in this chapter date from September to December of 1565. The chapter does not include all of Mary's letters over the year. Strickland includes only four letters from 1565, with Labanoff presenting four additional letters from the same year. The Calendar of State Papers, Scotland lists a total of seventeen letters written by Mary during the year, a large majority to Elizabeth Tudor, who was ruling in England. Letters from the early part of Mary's reign in Scotland are relatively sparse. The first letter written by Mary in Labanoff's collection dates from the year 1563. Strickland's earliest letter dates from 1558 or 1559. Rayne Allinson notes that much of Mary's correspondence with Elizabeth from the early years of her reign has been lost. ${ }^{68}$ In order to examine how Mary used letters as a form of foreign diplomacy, choosing a period from later in her personal reign provides more insight into Mary's personal rule. Though Mary had been raised her entire life knowing she was to be queen, she had never been directly responsible for its rule when she returned in 1561. Regents had been responsible for the rule of Scotland since the death of the former king, James V, a few days after his daughter's birth. Examining Mary's personal style of diplomacy and assertion of sovereignty requires examining a period after her arrival in the country but still before the

\footnotetext{
${ }^{68}$ Rayne Allinson, A Monarchy of Letters: Royal Correspondence and English Diplomacy in the Reign of Elizabeth I (New York: Palgrave Macmillan, 2012), 73.
} 
events that would lead to her forced abdication. Examining letters from 1565 shows Mary as a more settled and mature ruler with more experience, allowing us to examine Mary's developed diplomatic and rhetorical styles, which has not been previously examined by scholars.

While the other significant event of 1565 , the queen's marriage to Robert Darnley, might seem like a more obvious choice for the study of her queenship and approaches to diplomacy, the letters surrounding English incursions into Scottish territory and the imprisonment of Scottish subjects provide material that is revealing of one of the principal diplomatic challenges of Mary's reign: the conflict over whether to abandon Scotland's historical alliance with the French in favour of a new alliance with England. The dissent over Mary's choice of Robert Darnley as her new husband came from sources both foreign and domestic. The queen's conflicts with her own nobles over religion and domestic policy are well documented and have been analysed by numerous scholars, even if the inclusion of the study of letters is minimal. ${ }^{69}$ The marriage debates would be difficult to examine given that the scope of this thesis takes letters as the primary source of inquiry. Given the scope of this thesis, the first chapter will examine five letters written by Mary. The first two letters were written to Thomas Randolph, Elizabeth's ambassador in Scotland. The fourth letter was written to Philip II of Spain. The third letter examined in this chapter was addressed to Archbishop James Beaton who

${ }^{69}$ See Gordon Donaldson, All the Queen's Men: Power and Politics in Mary Stuart's Scotland; Alexandra Nancy Johnson, "Mary Stuart and Her Rebels-Turned-Privy Councillors: Performance of the Ritual of Counsel," in Queenship and Counsel in Early Modern Europe; and Kristen Post Walton, Catholic Queen, Protestant Patriarchy: Mary, Queen of Scots, and the Politics of Gender and Religion. 
was Mary's ambassador to the French court. The fifth and final letter was written by Mary to Elizabeth.

The letters to Randolph as well the letter to Elizabeth are all indicated as copies by the catalogue of the collection at the British Library. The idea of a copy of a letter during this period is complex. None of the manuscript letters being examined in this study are letters that were sent through postal systems, but rather copies made in order to preserve the information contained within sent letters. James Daybell indicates that the presence of a seal and endorsements are what demarcate a letter that was actually sent as opposed to a draft or a copy for filing purposes. ${ }^{70}$ In this case it makes sense that these manuscript letters might be copies of originals made by one of Cecil's secretaries and kept as records. Andrew Gordon, however, makes a powerful statement that within the epistolary culture, copying was an accepted and useful practice and a letter that is copied was usually accepted as a truthful duplicate of the original. ${ }^{71}$ Secretaries were largely responsible for the filing and copying of correspondence and instructions for the process are often found in secretarial guides of the period. ${ }^{72}$ Though occasionally the name of the secretary was included in the copy, these letters do not have any such indication. ${ }^{73}$ In addition to these practices, ambassadors often kept copy-books of letters both ingoing and outgoing on their person as they were often travelling, as well as copies of any orders they received. ${ }^{74}$ These procedures show why many of Mary's letters are housed in a

\footnotetext{
${ }^{70}$ James Daybell, The Material Letter in Early Modern England: Manuscript Letters and the Culture and Practices of Letter-Writing, 1512-1635 (New York: Palgrave MacMillan, 2012), 6.

${ }^{71}$ Andrew Gordon, "Material Fictions: Counterfeit Correspondence and the Culture of Copying in Early Modern Britain," in Cultures of Correspondence in Early Modern Britain, eds. J. Daybell, A. Gordon (Philadelphia: University of Pennsylvania Press, 2016), 109.

${ }^{72}$ Daybell, The Material Letter in Early Modern England, 219.

${ }^{73}$ Daybell, The Material Letter in Early Modern England, 198.

${ }^{74}$ Daybell, The Material Letter in Early Modern England, 178.
} 
number of repositories in England such as the British Library and The National Archives. The culture of copying letters during the early modern period is complex but the examination of Mary's letters to English recipients benefits from this social and material context.

\section{Religious and Diplomatic Context: Return to a Reformed Scotland}

While the letters discussed in the chapter were written years after these incidents described below, it is important to establish the context of the epistolary and diplomatic relationship between Mary and Elizabeth, Mary and her Lords, as well as her relationships with other foreign rulers. Mary arrived in Scotland in August of 1561 after having spent most of her life abroad. Widowed after the sudden death of her husband, Francis II, Mary returned to reign over the kingdom which had been her inheritance from the time she was days old. Marie de Guise, Mary's mother and regent had died the same year as Francis and Mary would rule alone for the first time in her life. Since the queen had inherited her crown at such a young age, regents had been responsible for the governance of Scotland since the death of James V, her father. James Hamilton, the second earl of Arran, was the first to serve as Mary's regent in Scotland. Arran served as the regent with the support of many of the nobles as he had a blood claim to the regency through a relation to James II. ${ }^{75}$ Arran was pro-English, which made Marie de Guise, Mary's mother, and later regent, nervous. In 1554, Arran surrendered the regency to Mary's mother, but remained one of her close advisors. One of Marie de Guise's primary goals for her regency was to ensure that her daughter's marriage to the French dauphin would result in a strengthening of the diplomatic partnership between Scotland and

\footnotetext{
${ }^{75}$ John Guy, Queen of Scots: The True Life of Mary Stuart (New York: Mariner, 2004), 19.
} 
France, called the auld alliance in Scots. In order to achieve this goal, Guise was forced to compromise with Protestant reformers so the crown matrimonial would be given to Mary's husband Francis which, due to his early death, never happened. ${ }^{76}$ The crown matrimonial would make Mary and Francis co-rulers and would allow Francis to keep the Scottish throne if Mary predeceased him. Guise was determined to keep Scotland aligned with France rather than engage in a new alliance with the English.

After the death of Francis II, Catherine de' Medici, Mary's mother-in-law and a staunch opponent of the Guises, made it clear that there was no longer a place for Mary at the French court and Mary began to make plans to return home. ${ }^{77}$ There had been a substantial uprising in Scotland in 1559-1560 and Mary was returning to a country that had experienced significant turmoil during the course of its transition to a Protestant church. Contrary to what had happened in England when Henry VIII had legislated the break with Rome and the establishment of the Church of England, in Scotland religious reform was characterized by calls for change from the lower levels of society upward to the monarchy. ${ }^{78}$ Though the Henrician church of England was theologically Catholic, under Edward VI and Elizabeth I the church was further reformed to espouse a more firmly Protestant theology. Mary returned to Scotland, which now had a reformed church which was independent from the papacy and whose tenets she, as the monarch, did not espouse.

The conflict between Protestant nobles and Mary's staunch adherence to the Catholic faith would be one of the defining characteristics of her reign. However, the

\footnotetext{
${ }^{76}$ Kristen Post Walton, Catholic Queen, Protestant Patriarchy: Mary, Queen of Scots, and the Politics of Gender and Religion (New York: Palgrave Macmillan, 2007), 22.

${ }^{77}$ Guy, Queen of Scots, 115.

78 Walton, Catholic Queen, 21.
} 
politics of religion involved more than domestic affairs. Diplomacy and religion were fiercely intertwined during the period, especially as the two best candidates for Scotland's closest diplomatic ally held distinctly different religions. England under Elizabeth was firmly Protestant. The French crown, on the other hand, not only remained staunchly Catholic but also attempted to suppress reformed movements until the end of the sixteenth century. The French Wars of Religion, which represented multiple bloody conflicts between the Catholic monarchy and Protestant Huguenots over religious rights, spanned more than thirty years, beginning in 1562 . While Mary and Francis authorized the Scottish Reformation Parliament in 1560, Mary never ratified the acts of that parliament because of the anti-French attitudes that she and her mother believed to be necessary to the survival of Scotland. ${ }^{79}$ Generally those in Scotland who supported the Protestant faith were in favour of an alliance with the English and those who were adherents to the Catholic faith were pro-French. There are, of course, exceptions to this general alignment of confession and opinion on foreign policy. There were a number of Protestants in the Queen's Party following Mary's flight to England, and not all of them supported an alliance with the French. ${ }^{80}$ During this time of religious conflict both at home and abroad it made sense for many nobles to attempt to align their country with those who they believed would support their faith. This approach is applicable to the discussion in this chapter as Mary needed to maintain diplomatic relationships with rulers of both religions, as well as be mindful of the possibility of rebellion by her Protestant subjects.

79 Walton, Catholic Queen, 22-23.

${ }^{80}$ Gordon Donaldson, All the Queen's Men: Power and Politics in Mary Stuart's Scotland (New York: St. Martin's Press, 1983), 8. 
Before Mary returned to Scotland, she completed the traditional period of forty days of mourning for the death of her husband and completed a brief sojourn in the countryside before returning to the French court at Fontainebleau. ${ }^{81}$ Mary received nobles from England at the French court in February of 1561, including the Earl of Bedford, one of William Cecil's closest allies. Cecil, one of Elizabeth's most trusted advisors, was then serving as Elizabeth's Secretary of State. He had a long-established distrust of Mary, seeing her as a threat to the security of Elizabeth's reign due to her close claim to the English throne. While the first meeting went well, the second meeting on the eighteenth of February turned sour. Bedford insisted that Mary needed to ratify the Treaty of Edinburgh immediately, drafted by Elizabeth's commissioners and the Scottish nobles as a way to end the siege of Leith with the withdrawal of English forces from Scotland and which would establish a new Anglo-Scottish alliance. ${ }^{82}$ Both Bedford and his companion Throckmorton attempted to pressure Mary into ratifying the treaty. Mary openly refused to do so, stating that she was both without counsel on the matter and that the Scottish nobles had made the agreement without her input and thus could not ratify the treaty. ${ }^{83} \mathrm{In}$ an attempt to further defend herself, Mary also criticized Elizabeth to her envoys, complaining that she had broken some of her promises to Mary, including that she had failed to send Mary a portrait of her. Mary had already sent a portrait to Elizabeth and the lack of reciprocation offended Mary. ${ }^{84}$ On the following day, in their final audience, Mary defiantly told Bedford that if she acted without the counsel of her nobles, as he was pressuring her to do, she could only expect them to rebel against her as they had done

\footnotetext{
${ }^{81}$ Guy, Queen of Scots, 118.

${ }^{82}$ Guy, Queen of Scots, 119.

${ }^{83}$ Guy, Queen of Scots, 119.

${ }^{84}$ Guy, Queen of Scots, 120.
} 
against her mother. ${ }^{85}$ Mary had taken a strong stance toward the English nobles from the very beginning of her personal reign and showed she could not be pressured into making decisions as they may have hoped. This context is important, especially as Mary's letters to Randolph and Elizabeth which will be examined in this chapter concern the behaviour of the Earl of Bedford as he had taken one of Mary's subjects prisoner.

Following this meeting, Mary left Fontainebleau and began to travel through France to say goodbye to her relatives. During her journey, members of both the Catholic and Protestant nobility sent messengers to offer advice to the queen. While the Catholic nobles attempted to convince her to land at Aberdeen where an army could be waiting to march her to Edinburgh, Mary refused as she knew this would be tantamount to declaring war on the Protestant lords who controlled the parliament. ${ }^{86}$ Mary instead sought the counsel of her half-brother, the Earl of Moray, who led the Protestant faction and had an essential role in the Treaty of Edinburgh. After many days of discussion, he and Mary came to the agreement that Scotland would remain Protestant, even if many people in the country still adhered to Catholic beliefs. In return for this, Mary would be allowed to have a private Catholic mass in her chapel at Holyrood house. ${ }^{87}$ Moray then began his journey back to Scotland, through England, and did not continue on with Mary. Later, Mary stated that their separation adhered to diplomatic protocol as Moray had no commission or invitation from the Duke of Lorraine, whose court Mary would be visiting next. ${ }^{88}$ These events are another example of Mary attempting to both follow diplomatic protocol as well as negotiating with her councillors on matters of state. Though Mary

\footnotetext{
${ }^{85}$ Guy, Queen of Scots, 120.

${ }^{86}$ Guy, Queen of Scots, 121.

${ }^{87}$ Guy, Queen of Scots, 121-122.

${ }^{88}$ Retha Warnicke, Mary Queen of Scots (New York: Routledge, 2006), 63.
} 
made an early compromise with Moray about the religion of her country, she still did not ratify the treaty. Mary showed an early competence in politics and diplomacy, which will be explored further in her letters which she wrote during her personal reign.

Mary journeyed to Calais in the company of a number of her Guise relations in order to set off for Scotland. Elizabeth had originally refused Mary permission to travel through England on her journey home unless Mary ratified the Treaty of Edinburgh before her departure. ${ }^{89}$ Elizabeth changed her mind however and forwarded a letter granting Mary safe passage through England to Calais, but it arrived after Mary's departure. ${ }^{90}$ Elizabeth and Mary would continue to have a relationship despite this early conflict. Rayne Allinson notes that much of the early correspondence between the two queens has been lost, but that the remaining letters indicate that they had an epistolary relationship during the early years of Elizabeth's reign. ${ }^{91}$ Allinson reports that during her tenure as Queen of France, Mary sent Elizabeth letters written in her own hand that were signed jointly with her husband, Francis II. When letters concerned French affairs, they were written in French and signed by both Mary and the King. When they concerned Scottish affairs, they were sealed with Mary's Scottish signet but were subscribed by the Queen Regent and then the Scottish Privy Council following the death of the regent and Mary's mother, Marie de Guise..$^{92}$ During the time when her mother was acting as her regent, Guy reports that Mary signed blank sheets with "votre bonne soeur Marie" and sent these to Guise in Scotland which were used for sending letters to foreign rulers to

\footnotetext{
${ }^{89}$ Guy, Queen of Scots, 125.

${ }^{90}$ Warnicke, Mary Queen of Scots, 65.

${ }^{91}$ Allinson, A Monarchy of Letters, 73.

${ }^{92}$ Allinson, A Monarchy of Letters, 75.
} 
maintain diplomatic relationships with rulers abroad. ${ }^{93}$ Though Mary was not overseeing the rule of her country, diplomatic correspondence was still often issued in her name while she was living in France.

Mary's early years in Scotland were punctuated by periods of unrest, but generally she managed to balance her personal adherence to the Catholic Church and the Protestant religion of her people. One of the primary goals of Mary's early reign was to establish a line of succession, which meant she had to choose a husband. As with both Elizabeth and Mary Tudor, the debate over a spouse largely centered around marrying either a foreign noble or a local lord. Kristen Post Walton identifies Mary's choice of Robert Darnley as her husband as one of the most fundamental assertions of her authority as queen. ${ }^{94}$ Darnley was a Catholic and in choosing him Mary angered Elizabeth who claimed a right of veto over Mary's choice and who had supported Robert Dudley, her personal court favourite and a Protestant, as a suitor for Mary, in turn offering that Mary would be named as Elizabeth's heir should she not have any children. ${ }^{95}$ William Cecil, Elizabeth's closest advisor, feared that the marriage to Darnley, who was English born and who had his own claim to the English throne, through Margaret Tudor, would mean that English support of Mary and Darnley as rulers over Elizabeth could easily be rallied. ${ }^{96}$ Regardless of Elizabeth's disapproval, Mary and Darnley were wed in July of 1565 , just a few months before many of the letters examined in this chapter were written.

Mary's Letters to Ambassadors: September to October 1565

\footnotetext{
${ }^{93}$ Guy, Queen of Scots, 78.

${ }^{94}$ Post Walton, Catholic Queen, Protestant Patriarchy, 91.

${ }^{95}$ Guy, Queen of Scots, 200.

${ }^{96}$ Guy, Queen of Scots, 204.
} 
The first three letters in this chapter were written by Mary to ambassadors. All of these letters concern very particular business. Mary asks for the release of her subject, grants permission for someone to be sent to her court from England and requests intelligence from the French court. These letters all show Mary asserting her political power in the epistolary form in making requests and granting privileges.

We shall examine a letter written by Mary to Thomas Randolph, Elizabeth's ambassador to the Scottish court on September 8, 1565 from Glasgow. ${ }^{97}$ The letter from Mary to Randolph is short, only about half of a page, and it is succinct and to the point. The letter is an example of an epistle which discusses specific business. John Gordon, the Earl of Sutherland, a Scottish subject, had been called back to Scotland by Mary after he had spent two years in Flanders following a charge of treason. The Earl had been implicated as a co-conspirator of his kinsman, the Earl of Huntly who rebelled against the queen in $1562 .{ }^{98}$ While this event is minor within the context of Mary's overall reign (so minor indeed that neither Warnicke nor Guy mention it in their biographies of Mary) the appearance of the incident in a letter to Randolph is interesting because it shows that Mary was responding to a challenge of her authority by those in another country. Mary reported to Randolph that the earl, "a bourne Subject of this our realme," had been captured on his journey "towardes this his natural countrie." 99 Mary's request was simple and direct. She asked Randolph to "write to the Earle of Bedford with the bearer hereof

97 British Library, Lansdowne MS 8, f. 121.

${ }^{98}$ Allan White, "Gordon, John, eleventh Earl of Sutherland," Oxford Dictionary of National Biography (September 2004: Accessed November 25, 2020). https://www-oxforddnbcom.proxy.library.carleton.ca/view/10.1093/ref:odnb/9780198614128.001.0001/odnb9780198614128-e-11060.

${ }^{99}$ Mary Stuart, Queen of Scotland, “Copy of the Q. of Scots' letter to Mr. Randolph” British Library, Lansdowne MS 8, f. 121. 
thus by your letter the same Earle of Sutherlande may be put at libertie and Suffred to depart hence towards this our realme." ${ }^{100}$ A man who was her subject and who she specifically requested return from exile was being held contrary to her wishes. In order to respond to this challenge to her authority, Mary turned to a letter in order to display her power and exert her influence in order to prove her sovereignty in this matter.

Whether or not Randolph actually wrote the letter to the Earl of Bedford is unclear. If Randolph did write the letter it was not retained in the Burghley Papers collection at the time of the collection's purchase by the British Museum, as the catalogue contemporary to the purchase makes no reference to it. Other letters of Randolph's to Elizabeth and to the Scottish Privy council from around the same time were retained in the Burghley Papers, now at the British Library as well as in the Calendar of State Papers Scotland, now housed in the National Archives, making it seem unlikely that Randolph wrote to Bedford at the queen's request. ${ }^{101}$ Regardless of whether Randolph wrote the letter to Bedford, Mary's attempt to have Sutherland freed was unsuccessful. Sutherland was not freed until the next year. Elizabeth in fact had him released on the request of Mary's brother the Earl of Moray. ${ }^{102}$ Realistically, it was only Elizabeth who would have had the power to command the Earl of Bedford to release Sutherland, as was the case with his eventual release. Mary was attempting to use her

\footnotetext{
${ }^{100}$ Mary Stuart, "Copy of the Q. of Scots' letter to Mr. Randolph" f. 121.

${ }^{101}$ According to the Calendar of State Papers Scotland, Randolph wrote to the Earl of Bedford on September 9, but the letter revolved largely around Randolph forwarding letters to him and does not mention the queen, Sutherland, or the content of the letters he was forwarding, thus making it seem unlikely that the letter contained any reference to the queen's request. 'Elizabeth: September 1565', in Calendar of State Papers, Scotland: Volume 2, 1563-69, ed. J. Bain (London, 1900), 199-216, accessed through British History Online.

${ }^{102}$ Allan White, "Gordon, John, eleventh Earl of Sutherland," Oxford Dictionary of National Biography.
} 
relationship with Randolph, despite the fact that he was not her subject, to assert her authority over a man who was her subject. Mary and Randolph had a long relationship as he had been in her court as Elizabeth's ambassador for the entirety of her personal reign.

Mary's letter, though brief, shows a curious tactic for this diplomatic missive as well as being somewhat of a diplomatic anomaly. Mary emphasized that Sutherland is "a bourne Subject" of her realm and therefore established that he was both under her command and is her responsibility. ${ }^{103}$ While it is never explicitly stated, Mary was implying that the detainment of her subject in England is unwarranted with a repeated emphasis of his status as her subject and Scotland as his "natural countrie." 104 Written in one of the final lines of the letter, is the phrase, "Subscrybed with our hand," indicating that the sent missive was not copied by the queen. ${ }^{105}$ Indeed the signature on the document might have not been Mary's as it was common practice for scribes and secretaries to sign letters on behalf of the sender. ${ }^{106}$ The indication that the letter was physically written by someone other than Mary shows that it was likely not considered to be a deeply personal note. James Daybell notes that to write in one's own hand, also known as an autograph letter, was seen as more personal, which does not fit the tone of the rest of the note, nor its context. ${ }^{107}$ While some diplomatic letters, like those from Mary to Elizabeth, were autograph, the fact that this letter was written to a diplomatic agent, rather than a family member or fellow ruler, means that the letter would not warrant the queen's hand. The letter is very to the point, it does not contain much

\footnotetext{
${ }^{103}$ Mary Stuart, "Copy of the Q. of Scots' letter to Mr. Randolph" f. 121.

${ }^{104}$ Mary Stuart, "Copy of the Q. of Scots' letter to Mr. Randolph" f. 121.

${ }^{105}$ Mary Stuart, "Copy of the Q. of Scots' letter to Mr. Randolph" f. 121.

${ }^{106}$ Daybell, The Material Letter in Early Modern England, 23.

${ }^{107}$ Daybell, The Material Letter in Early Modern England, 86.
} 
emotional language, or even argue why the Earl should be released, simply that Randolph should write to Bedford with the purpose of attaining Sutherland's release. There is a brief reference to "the good Intelligence betwixt us and our good sister the Queen," indicating that Mary believed Elizabeth did not have any knowledge of the imprisonment or else she would have informed her, but beyond that there is no justification for why the Earl should be released. ${ }^{108}$ While the letter is short it is also assertive. Mary did not feel the need to justify herself and was simply stating her purpose and expects it to be followed through on, despite having no jurisdiction in England. She of course does have jurisdiction over Earl of Sutherland as he is one of her subjects, which she is careful, as noted, to emphasize repeatedly. This letter is one of a sovereign who is confident in her authority and is attempting to assert that authority by freeing one of her subjects when he had been imprisoned on his way home.

Mary also addressed Randolph at the beginning of the letter as "Trustie and wellbeloved." ${ }^{109}$ In the second letter Mary wrote to Randolph she used the same mode of address. ${ }^{110}$ The two had a long-established relationship as he had been at her court for many years. However, it seems that it was not only Mary who referred to Randolph in this manner. Following his post in Scotland, Randolph was sent by Elizabeth to be her ambassador in Russia from 1568 to 1569 , during which time Mary was imprisoned in England. When Randolph returned to England, he carried a letter from Tsar Ivan to Elizabeth in which he similarly referred to the ambassador as being "trustie." "111 It appears

\footnotetext{
${ }^{108}$ Mary Stuart, Queen of Scotland, "Copy of the Q. of Scots' letter to Mr. Randolph" f. 121. ${ }^{109}$ Mary Stuart, Queen of Scotland, "Copy of the Q. of Scots' letter to Mr. Randolph" f. 121.

${ }^{110}$ Mary Stuart, Queen of Scotland. "Copy of the Q. of Scots' letter to Mr. Randolph" British Library, Lansdowne MS Vol 8, f. 114.

${ }^{111}$ Jan Hennings, "Textual Ambassadors and Ambassadorial Texts: Literary Representation and Diplomatic Practice in George Turberville's and Thomas Randolph's Accounts of Russia," in
} 
that Mary, though seeming to break diplomatic protocol by writing to Randolph rather than directly to Bedford or to Elizabeth, continued to adhere to the diplomatic conventions necessary when writing to an ambassador employed in other letters to Randolph from this period.

The second letter, also written to Randolph, this time from Stirling Castle, is also from the Lansdowne Collection. ${ }^{112}$ The date of this letter is more uncertain than the first letter but likely comes from a few days either before or after the previously discussed letter to the ambassador. This letter is another contemporary copy from the Burghley Papers, a part of the Lansdowne Collection. The issue with the dating of this letter is that the catalogue of the collection does not provide a specific date for the letter and merely marks it as being from 1565 . In the body of the letter, however, it is noted that it is from September. The only mention of the year is actually written on the document, likely from the time that the document was acquired by the British Library, recorded in an ink different from that used in the body of the letter. The text of the letter itself marks that it was "Subscrybed in $\mathrm{o}^{\mathrm{E}}$ [our] hand at $\mathrm{o}^{\mathrm{E}}$ [our] castle of Stirling on the $\mathrm{r} 7^{\text {th }}$ of wot September." There are multiple crossings out on the final line in which the date is inscribed in this copy of the letter, as indicated in the diplomatic transcription of the passage above. While the modifications to the line of the letter which reference the date are not necessarily indicators of a misdating of the letter, the number of crossings in that particular line calls into question the accuracy of the copy. This dating is further complicated by letters that are more firmly dated from around the same time. The above

Cultures of Diplomacy and Literary Writing in the Early Modern World, ed. T. Sowerby, J. Craigwood (Oxford: Oxford University Press, 2019), 186.

${ }^{112}$ Mary Stuart, Queen of Scotland. "Copy of the Q. of Scots' letter to Mr. Randolph” British Library, Lansdowne MS Vol 8, f. 114. 
letter from September 8 to Randolph was apparently written from Glasgow, as was a letter from September 10 to the King of Spain, which will be discussed later in this chapter. The trip from Stirling to Glasgow is around twenty-four miles, which, while possible for a single person to complete in a day, even on foot, would likely not be possible for the whole court to move from one castle to another. On the $13^{\text {th }}$, Guy notes that Mary had issued a proclamation at St. Andrews against a small group of rebels and by the $20^{\text {th }}$ was back at Holyrood in Edinburgh. ${ }^{113}$ As Guy also reports that Mary was closely following her troops as they attempted to chase down the rebels it seems possible she was moving quickly around the country and that these dates may all be accurate, but it is significant as this project is the first appearing to make a positive assertion about the date of this letter in particular.

Regardless of the dating of the letter, it shows a significant attempt on Mary's part to exercise political power in controlling the diplomatic relations of her court. Mary uses this letter to send a message to Elizabeth without writing to her personally. The letter is a page longer than the previously examined missive and its content is far less straightforward and businesslike. The catalogue of the Lansdowne Collection summarizes the purpose of the letter as informing Randolph that "as a Minister is coming to her from the K. of Spain, together with a messenger from the Q. of England to accommodate matters betwixt the two realms, she freely consents thereto." 114 "Freely" is perhaps a generous adjective to describe Mary's feelings on the matter. In this letter, although Mary stated that whoever is assigned from England to travel to her court should be pleased,

\footnotetext{
${ }^{113}$ Guy, Queen of Scots, 221.

${ }^{114}$ British Museum, A Catalogue of the Lansdowne Manuscripts in the British Museum: With Indexes of Persons, Places and Matters, (London: British Museum, 1819), 15.
} 
“especiallie comying for so good an errand," there are also some explicit warnings to Elizabeth in the text. ${ }^{115}$ After Mary had consented to Elizabeth sending someone to her court, she made very clear the limits she wished to impose upon Elizabeth's subject. Mary stated that she "will not consent that our same good sister or her mynisters upon her behalffe shall meddle any wise betwixt us and any of our Subjectes." "116 This statement in the letter shows that Mary was attempting to assert that although Elizabeth may send a subject to her court, it is expected that Elizabeth must respect her sovereignty. Mary asserting her power explicitly, rather than veiling her intentions, was necessary as she was often being challenged by her own subjects as well as by Elizabeth. The conflict between Mary and Elizabeth over Mary's search for a new husband exemplified the degree to which Elizabeth was attempting to insert herself into her cousin's affairs for her own benefit. Elizabeth believed that having Robert Dudley wed Mary meant that she would have more influence in the affairs of Scotland by having her greatest rival marry one of her most trusted advisors. ${ }^{117}$ Mary also rightly feared that her subjects might be turned against her. She knew that her situation with some of her lords was tenuous. Her marriage to the Catholic Darnley had not gone over well, especially with Moray, who was angry that his sister had endangered the alliance with England by not accepting Elizabeth's choice of suitor, thus prompting the Chaseabout raid in July of $1565 .^{118}$ Mary's writing in this letter shows her attempt to assert her power in her own realm while continuing to engage in the appropriate diplomatic procedures which were expected. Mary used Randolph as an intermediary for her message to Elizabeth, thus allowing her

\footnotetext{
${ }^{115}$ Mary Stuart, Queen of Scotland. "Copy of the Q. of Scots' letter to Mr. Randolph" f. 114.

${ }^{116}$ Mary Stuart, Queen of Scotland. "Copy of the Q. of Scots' letter to Mr. Randolph” f. 114.

${ }^{117}$ Guy, Queen of Scots, 185.

${ }^{118}$ Guy, Queen of Scots, 198.
} 
to be more straightforward with her warnings, reducing the chance of disrespect to her cousin as the letter was not directly written to her but by one of her subjects. Mary was attempting to walk a careful line between maintaining an alliance with England, without making herself vulnerable to rebellion from her subjects or interference from Elizabeth.

The next letter is another written to an ambassador, this time to one of Mary's own subjects. The letter was written to the Archbishop of Glasgow, James Beaton, on October 1, from Lislebourg. As this letter comes from Strickland's edition of Mary’s letters, no manuscript number is provided. Mary appointed Beaton as her ambassador to the French court, a position he retained until her abdication. This letter shows the ways in which Mary used letters to her ambassadors in order to support diplomatic processes during her personal reign. This letter is slightly different to the ones to Randolph as, in this case, Beaton, the ambassador, is her own subject rather than Elizabeth's. Mary began the letter by admonishing Beaton for his lack of communication with her, saying that she was "greatly astonished," by this and that she wants "to hear oftener," from him. ${ }^{119}$ This statement immediately establishes the relationship between Mary and her ambassador. Mary could not issue such a command to Randolph as he was not her subject. In the case of writing something similar to another ruler, it would not be restricted, but it would be more an emphasis on the desire to establish a personal relationship with them rather than a command. Rayne Allinson reports that Mary told Randolph that she wished Elizabeth would write to her more as she longed to hear from her. ${ }^{120}$ This statement was part of the performance which Mary used throughout her personal reign in order to establish that she

\footnotetext{
${ }^{119}$ Mary Stuart, Queen of Scotland, "Letter Dated October 1, 1565: The Queen of Scots to the Archbishop of Glasgow," in Vol. 1 of Letters of Mary Queen of Scots, ed. Agnes Strickland (London: Henry Colburn, 1842), 17.

${ }^{120}$ Allinson, A Monarchy of Letters, 77.
} 
had affection for Elizabeth and that she was committed to their diplomatic and personal relationship. In this case, Randolph was often used as a way of communicating Mary's intentions back to the queen as he often delivered her letters and witnessed Mary kissing them and using other performative gestures of gratitude. ${ }^{121}$ In writing to her own ambassador, Mary did not need to use these performances, and could merely communicate these desires explicitly. In addition, Mary makes it clear that the information Beaton could be writing to her was necessary to managing diplomatic relations abroad as well as affairs at home.

Later in the letter, Mary made it explicitly clear what she needed from her ambassador. Mary urges Beaton to "keep a good look-out and see if my rebels hold any secret communication over there with Protestants or Chantillion." ${ }^{122}$ Mary was, at the time, facing a threat from her brother, Moray, primarily due to her decision to marry Henry Darnley. ${ }^{123}$ Mary's authority was being threatened in a very real way, with armed rebels seeking to overthrow her. Naturally at this time she needed reassurance that the rebels were not attempting to undermine her alliance with France, a close ally. The conflict between French Protestants and the French monarchy was intensifying on the continent and Mary obviously feared an alliance between the French Protestants and her own rebels, a large majority of whom were of the reformed religion. Mary also commanded Beaton to discover "if the Duke and the Earl of Murrey have any agent about the queen, whom you may assure that they have full liberty of conscience, and that this is not the motive which influences them." 24 "Murrey" is a reference to her brother, whose

\footnotetext{
${ }^{121}$ Allinson, A Monarchy of Letters, 77-78.

${ }^{122}$ Mary Stuart, Queen of Scotland, "Letter Dated October 1, 1565," 19.

${ }^{123}$ Guy, Queen of Scots, 220.

${ }^{124}$ Mary Stuart, Queen of Scotland, "Letter Dated October 1, 1565,” 19.
} 
title as the Earl of Moray was often interchangeably written in Scots. Mary needed to determine if her rebels had conspirators at the French court, and additionally assure the queen, Catherine de' Medici, that it was not her suppression of their religion that was the cause of their rebellion. Mary wanted to ensure the queen knew that this rebellion was a threat to her sovereignty rather than a conflict over religion. In the letter, Mary showed that she had authority over her ambassador in the simple manner that she gave him a series of instructions, but there was a more nuanced display of authority here. Once again, through the intermediary of an ambassador, as she did with Randolph, Mary attempted to communicate intentions to another ruler. Mary wanted it known to Catherine de' Medici, who held a considerable amount of power as the mother of the young king, Charles IX, that her rebels were not to be trusted as they threatened her rightful rule. Mary's needs for intelligence were not her only motivation for her letter to the archbishop. Mary wrote that the archbishop should "urge the queen as often as you can, and by all the means in your power, to send us men and money in this emergency, and then write forthwith what I have to hope for." ${ }^{125}$ In this letter, there are concrete requests for a specific kind of support from France in order to assist in the suppression of the rebellion. While Mary did not provide her ambassador with specific arguments to give to the queen about the necessity of this assistance, she urged him to use all his power to ensure she received the support she needed. This work was the purview of ambassadors, who acted on behalf of their monarchs in order to support their goals. Mary was following diplomatic protocols, advising her ambassador to encourage support from the French court. The letter again shows Mary participating in a diplomatic network of

\footnotetext{
${ }^{125}$ Mary Stuart, Queen of Scotland, "Letter Dated October 1, 1565,” 18.
} 
ambassadors and the courts of different monarchs. As Randolph was expected to support Elizabeth's interests to Mary, so too was Beaton expected to support Mary's interests to Catherine, who, though she was no longer the regent at the time the letter was written, still held a considerable amount of power.

Despite the immediate establishment of Beaton as her subject, mandated to do her bidding, Mary ended her letter on a kind note. Mary signed the letter, "your very good mistress and friend, Mary R." ${ }^{126}$ Mary both reminded her subject that she was his mistress but also called him a friend, as an attempt to maintain and recall their positive relationship as the two were very close as his cousin, Mary Beaton, was one of the queen's ladies. It is difficult to compare the closing address of this letter to others, especially that to Randolph as the copies of the letters contained in the British Library do not appear to have this section included in the copy. In addition, the opening address of the letter is missing from the copies. ${ }^{127}$ The copies do contain the date of the letter, included in the body of the letter. As the letters from Strickland's edition are from the same time and the closing address were common at that time it seems that perhaps the person who copied these letters did not copy this section as it was mere formality. James Daybell notes that the opening and closing address were almost always on the sheet which also contained the text of the letter during this period, meaning that the secretary copying the letter would have almost certainly had access to this information. ${ }^{128}$ Often when compiling letters into registers or copy-books, the greetings or modes of address were shortened for the sake of speed and the priority was placed on replicating the text of

\footnotetext{
${ }^{126}$ Mary Stuart, Queen of Scotland, "Letter Dated October 1, 1565," 20.

${ }^{127}$ An example of this would be "to the King of Spain, my good brother," from Mary's letter on September 10. Mary Stuart, Queen of Scotland, "Letter Dated September 10, 1565," 16.

${ }^{128}$ Daybell, The Material Letter in Early Modern England, 12.
} 
the letter. ${ }^{129}$ Given the copying practices, it is difficult to establish a significant difference in the manner Mary used greetings or modes of address across copied letters and the letters presented in Strickland's edition. These letters all focus on the maintenance of her diplomatic network. Largely these letters do not have appeals to logical argument as Mary outranks her recipients and is able to make requests without justification.

\section{Letters to Fellow Rulers: September to December 1565}

During this period, Mary also wrote to fellow rulers as a method of diplomacy. Due to the different audience, different rhetorical strategies were used and focussed on more ephemeral ideas of kin and justice than the direct instructions of the previous section. Mary wrote to Philip II of Spain on September 10, 1565 from Glasgow. As with the letter to Beaton, this example comes from Strickland's edition and thus has no call number or any indication where the manuscript is held. The letter contains no reference to particular business between the two rulers but there are repeated calls to ties of kinship and religion in order to maintain the diplomatic relationship between them. Mary was attempting to maintain support from Philip as a fellow Catholic monarch, especially in light of her recent marriage which strengthened her claim to the English throne. At this time Philip was married to Elisabeth de Valois who was Mary's sister-in-law through her marriage to Francis II. Elisabeth and Mary were very close as they grew up in the French court together and Henry II had emphasized the importance of the two girls being brought up as sisters when Mary first arrived at court. ${ }^{130}$ The two women remained close until Elisabeth's death. In addition to this emotional connection, when Francis II and Mary were wed, Mary and Elisabeth became sisters by marriage. Thus, when Mary addresses

\footnotetext{
${ }^{129}$ Daybell, The Material Letter in Early Modern England, 183.
}

${ }^{130}$ Guy, Queen of Scots, 46. 
Philip as "my good brother," there is actually a genuine family connection, despite it being more distant than Mary's relationship with Elizabeth Tudor, her cousin by blood. ${ }^{131}$ However, the address is encoded in the conventions of epistolary diplomacy from the period. When rulers wrote letters to one another, the language of familial relations was often employed as a way to emphasize both a shared sovereignty but also a membership in a princely class. ${ }^{132}$ Even before she returned to Scotland, Mary was familiar with this strategy in correspondence with other rulers. Similar to the manner in which her letters to Randolph were addressed, Mary is using specific epistolary conventions in order to establish the diplomatic nature of the missives. She is employing the conventions of princely correspondence as well as calls to kinship ties during the period in order to firmly establish her position as a sovereign ruler and a natural ally.

At this time Philip headed one of the most powerful Catholic countries in the world and Mary, in her letter, emphasizes that their shared religion formed a bond between them. Post Walton asserts that Mary was primarily interested in maintaining support from Philip for the succession to the English throne, especially following the elimination of his son as a marriage prospect in $1564 .{ }^{133}$ In her personal reign Mary both sought to maintain a policy of tolerance, allowing the Protestant Kirk to operate freely while maintaining her personal Catholicism, as well as to ensure she had support from the Catholic powers throughout Europe for her appointment as Elizabeth's heir. Mary

\footnotetext{
${ }^{131}$ Mary Stuart, Queen of Scotland, "Letter Dated September 10, 1565: The Queen of Scots to Philip II," in Vol. 1 of Letters of Mary Queen of Scots, ed. Agnes Strickland (London: Henry Colburn, 1842), 16.

${ }^{132}$ Tracey A. Sowerby, "Negotiating with the Material Text: Royal Correspondence between England and the Wider World," in Cultures of Diplomacy and Literary Writing in the Early Modern World, ed. T. Sowerby, J. Craigwood (Oxford: Oxford University Press, 2019), 205.

${ }^{133}$ Post Walton, Catholic Queen, Protestant Patriarchy, 115.
} 
suppressed a rebellion begun by the Catholic Earl of Huntley in 1562, just a year after her arrival back in the country. Despite the Earl being Catholic, Mary's suppression of the rebellion meant that she gained further support from Protestant nobles, something she needed in order to cement her authority as queen. ${ }^{134}$ However it was not merely her own subjects from whom Mary needed support during her reign. The relationship with Catholic rulers was important for Mary to maintain as she needed allies, with one of the easiest points of connection between them being shared religion.

The desire for support is very clear from the letter, but the succession to England is not mentioned explicitly but merely hinted at. Mary instead momentarily downplayed her policy on tolerance and details to Philip the poor treatment of Catholics in her country. She cited his strong dedication to the "maintenance and support of our Catholic religion" as her reasoning for seeking his assistance. ${ }^{135}$ Mary stated that Catholicism is suffering in Scotland with, "the establishment of those unfortunate errors, which, were I and the king my husband to oppose, we should be in danger of losing our crown, as well as all pretentious we may have elsewhere, unless we are aided by one of the great princes of Christendom." ${ }^{136}$ With this statement Mary presented herself as a stalwart protector of her religion, but also in a way also showed herself as powerless and in need of aid. The strategy which Mary employed presented herself both as dedicated to her religious beliefs but as unable to truly pursue this dedication without support from other rulers who have the same convictions. This presentation of Mary provides an explanation as to why she

\footnotetext{
${ }^{134}$ Post Walton, Catholic Queen, Protestant Patriarchy, 90.

${ }^{135}$ Mary Stuart, Queen of Scotland, "Letter Dated September 10, 1565: The Queen of Scots to Philip II," in Vol. 1 of Letters of Mary Queen of Scots, ed. Agnes Strickland (London: Henry Colburn, 1842), 16.

${ }^{136}$ Mary Stuart, Queen of Scotland, "Letter Dated September 10, 1565," 16.
} 
had not acted in order to restore Catholicism to Scotland, given her open and sincere faith. Mary is showing her policy of tolerance as something that is beyond her choice if she wants to maintain her crown. Additionally, as Mary stated that she and her husband Darnley might lose not only the Scottish throne but also, "all pretentions we may have elsewhere," she was also hinting at their possible role in the English succession. ${ }^{137}$ Philip, as with many of the Catholic powers in Europe at the time, including those in France, believed that a Catholic monarch, likely Mary, returning to the English throne, might mean a more permanent return to Catholicism for the country. Mary made the argument that if they lost their crowns in Scotland, any hope there was of further supporting Catholicism in Britain would be lost as well. In this letter Mary was creating an image of herself which would support her goal of maintaining a diplomatic relationship with Philip while still allowing her to support the policy of religious tolerance which was necessary to protect her rule.

When comparing the letter to Philip from September 10 to the letters to Randolph and Beaton there is a distinct difference in the requests that were made. When Mary wrote that the purpose of her letter to Philip was "to solicit your advice, and to strengthen ourselves with your aid and your support," the type of aid she was seeking remained vague. ${ }^{138}$ Mary was not asking for military or financial support but merely kept her request focused on supporting their shared religion. The letters to the two ambassadors, by comparison, are far more specific in terms of what their purposes were. The purpose of the letter of September 8 was to have the Earl of Bedford released and the purpose of the second was to inform Elizabeth through Randolph that another of her subjects could

\footnotetext{
${ }^{137}$ Mary Stuart, Queen of Scotland, "Letter Dated September 10, 1565," 16.

${ }^{138}$ Mary Stuart, Queen of Scotland, "Letter Dated September 10, 1565," 17.
} 
come to her court, with certain conditions. The letter to Philip performed a far less concrete function as it was more geared towards diplomacy in the abstract: the maintenance of alliances based on shared belief and goals. The letter was intended to show Philip why Mary had not yet attempted to overthrow the new Protestant Kirk and also reaffirm to him that she was still committed to their shared faith and that she had the potential to restore Catholicism to both Scotland and England. The letters to Randolph and Beaton both show Mary's involvement in the everyday workings of diplomacy at court: who would be allowed to court and when, as well as the welfare of her subjects abroad. These two different types of diplomacy necessitated different expressions of power, with the former requiring a call to her faith and her commitment to protecting it and the latter requiring an assertion of power over her own subjects and those who would attend her court.

The final letter was written on December 31, 1565 to Elizabeth from Holyrood and is housed in the Lansdowne Collection, volume 8, folio 94. Mary wrote this letter to Elizabeth to discuss a raid into Scottish territory that had been reported to be authorized by the Earl of Bedford. Though seemingly distant from the events of September which prompted Mary’s letter to Randolph, this letter shows Mary attempting to discuss similar events with Elizabeth directly rather than through her ambassadors, which is useful as it can provide a point of comparison for Mary's epistolary approach to another ruler in contrast with an ambassador on similar topics. This letter once again concerns the Earl of Bedford but this time there is a wider issue at hand than the Earl of Sutherland. Mary wrote to Elizabeth that she had been "somerlie informed" that there were some English 
subjects who had "entred within our ralme of Scotland at the towne of Edington.".139 Mary reported that they "took prisoners, spoiled and rest a great Quantitie of goodes."140 Mary also claimed that the Earl of Bedford took accountability for the events, stating that he had said that the incursion into Scotland had been "doen at his commandment as your agent [Master] Randolphe, being present at the declaration thereof can testyfye." ${ }^{141}$ Raids such as these were common in towns on the border of England and Scotland. The raids clearly affected Mary and she saw them as an attack on her sovereignty that was authorized by one of the wardens of the border. Mary writes that Elizabeth should write to the Earl "for redress," in order to condemn his actions. ${ }^{142}$ Mary wanted action to be taken in order to admonish those who transgressed upon her authority. Elizabeth had the ability to make a statement condemning the raid to her subjects which would display that Elizabeth supported Mary's sovereignty over Scotland and would challenge any attempts to diminish. In contrast to her letter to Randolph, which was over the imprisonment of a single man, this situation was far more volatile and thus required Elizabeth's intervention. The incursion into Scottish territory, supposedly authorized by one of Elizabeth's lords, could have started a war if the situation was not rectified and thus Mary needed to write to her fellow queen personally in order to prevent any further hostility.

In this letter, Mary also needed to maintain the relationship and somewhat tenuous peace she had established with Elizabeth. Mary noted that the behaviour of the raiders was that of open warfare, "a thing which we understand to be expresse against

\footnotetext{
${ }^{139}$ Mary Stuart, Queen of Scotland. "Copy of the Q. of Scots' letter to the Q. of England; complaining of hostilities committed in Scotland by the English" British Library, Lansdowne MS 8, f. 97.

${ }^{140}$ Mary Stuart, Queen of Scotland. "Copy of the Q. of Scots' letter to the Q. of England," f. 97.

${ }^{141}$ Mary Stuart, Queen of Scotland. "Copy of the Q. of Scots' letter to the Q. of England," f. 97.

${ }^{142}$ Mary Stuart, Queen of Scotland. "Copy of the Q. of Scots' letter to the Q. of England," f. 97.
} 
your mynd and pleasure." ${ }^{143}$ She also stated that it had been Elizabeth's desire "to enterteyne peace and Quyetness amongst the Subjectes of bothe contryes." ${ }^{144}$ Mary wanted her letter to remind Elizabeth of their commitment to rule with relative peace between their countries. She expressed her hope that Elizabeth would "take hayste order that the said attempt at (sic) may be spedilie redressed and also to make plaine demonstration that ye mislyke this and many other strange procedinges." ${ }^{145}$ Mary was giving Elizabeth a chance to condemn the actions which had threatened her sovereignty in favour of peace between the two countries and to make plain to her subjects that an attack on Mary's sovereignty was not what she wanted. In contrast to her letters to both Randolph and Beaton, she could not present orders to a fellow monarch. Instead, Mary makes recommendations to Elizabeth which she presents as being beneficial to their shared goals. She requests that Elizabeth "ponder this matter according to the wright thereof," suggesting that the actions of her subjects was obviously unjust, given the circumstances. While Mary was unable to issue orders directly to Elizabeth, these suggestions are an attempt to both preserve their relationship in not taking an accusatory tone against Elizabeth herself and to assert that she was taking matters into her own hands by taking the complaints of her people to Elizabeth personally. In this letter Mary was attempting to shore up her own power by writing to ask that her cousin openly display that a challenge to her authority was not acceptable.

Contrary to the letter to Philip from September 10, Mary's letter to Elizabeth focussed on specific events that had occurred rather than a general attempt to garner

\footnotetext{
${ }^{143}$ Mary Stuart, Queen of Scotland. "Copy of the Q. of Scots' letter to the Q. of England," f. 97. ${ }^{144}$ Mary Stuart, Queen of Scotland. "Copy of the Q. of Scots' letter to the Q. of England," f. 97.

${ }^{145}$ Mary Stuart, Queen of Scotland. "Copy of the Q. of Scots' letter to the Q. of England," v. 97.
} 
support. In her letter to Philip, her request for support was far more general than the requests she made of Elizabeth. She requested that Elizabeth "make plaine demonstration that ye mislyke this and many other strange procedinges." ${ }^{146}$ Despite these differences, as both were written to other rulers, they have distinct similarities. Where Mary made calls to a common religion with Philip, she made calls to justice and a shared desire for peace with Elizabeth. In addition, there is an attempt at a distinct argument in both letters. In her letter to Elizabeth from December 31 she presents the threat of war between the two countries as a reason for Elizabeth to denounce the actions of those who violated Scottish territory and the Earl of Bedford who supposedly authorized the raid. In comparison to the letters written to the two ambassadors, the letter to Elizabeth is similar in that it concerns specific business and thus contains specific courses of action to be taken. Of course, the letter to Elizabeth differs in that the course of action cannot be ordered by Mary as she was writing to another monarch. In the case of the letter to Elizabeth, Mary presented an argument as to why she should follow Mary's recommended course of action: to maintain the peace between their two countries which Elizabeth had previously supported. Comparing the circumstances in which these letters were written reveals that Mary tailored how she managed challenges to her authority in diplomatic letters.

\section{Conclusions}

Mary participated in epistolary diplomacy throughout her personal reign in pursuit of a variety of goals. Underlining all of the letters, however, was Mary's attempt to assert her authority as queen regnant over matters both in her own country and abroad. Scotland had experienced a considerable amount of turmoil while regents were ruling for Mary

\footnotetext{
${ }^{146}$ Mary Stuart, Queen of Scotland. "Copy of the Q. of Scots' letter to the Q. of England,” v. 97.
} 
before she returned from France and Mary as the monarch needed to continually demonstrate her power in order to prevent rule falling to her opponents. Letters were a key way in which Mary accomplished the business of her rule. Letters were avenues in which Mary could conduct diplomacy in support of her goals for her country and her reign. The manner in which Mary tailored her assertions of authority to the recipients of her letter, often aided by epistolary convention, allowed her letters to be effectively assertive without offending her audience. In her letter to Randolph regarding another ambassador from England, Mary was able to issue a firmer warning to Elizabeth than she could have done by writing to the Queen directly because Randolph acted as an intermediary. She could even break some conventions, as in her letter to Randolph regarding the Earl of Sutherland, because she followed others. These letters allowed Mary to build and maintain diplomatic relationships while managing challenges to her sovereignty. 


\section{Chapter Two: Rank, Kinship and Justice in the Letters of a Captive Queen}

The letters examined in this chapter are from a much more turbulent period in Mary's life from those considered in the previous chapter. Much had happened since 1565. Most significantly, in May of 1568 Mary fled imprisonment in Scotland to seek safety in England. She would remain captive in England for almost two decades, a period that ended only with her execution in 1587 . The letters from this period, written in the first two months following Mary's imprisonment in England, show a wide variety of tactics on the part of the Scottish queen, showing her ability to write with the intention of achieving specific goals. The letters written in the two-month period following her imprisonment all serve Mary's primary goal of returning to her position as queen regnant of Scotland. Mary used letters as an important diplomatic tool during this period, especially at a time when she had very little recourse to exercise political power after her forced abdication. Not only are her letters an exercise in rhetoric, discussing the importance of rank, kinship and justice, but they also reveal the ways in which Mary expressed emotion in this diplomatic setting. She was able to use the emotional tone of her letters to emphasize the importance of certain goals.

The letters written by Mary early in her imprisonment in England show her resolute belief that her return to the throne of Scotland was still possible if she could only raise the necessary support. Despite the fact that they were mostly written while Mary was imprisoned, the letters show that even from captivity she continued to use correspondence as a tool of diplomacy. A significant reason for this continued political writing was that Mary still firmly believed not only that her return to power in Scotland was possible, but that it was just. Since she knew herself to be innocent of both her 
husband's murder and any of the abuses of her power she had been charged with by her nobles, Mary believed that she was still the rightful ruler despite her abdication. Mary used appeals to kinship, a focus on her pressing and immediate need for assistance and reminders of her status and rank. She also employed emotion in her letters in order to gain support for her return to power. Emotion was an essential part of building and maintaining relationships with other rulers, especially as relationships were often framed in language of kinship. Forging and maintaining connections with diplomatic allies was essential, especially at this point in Mary's life as she was isolated from many of her supporters. In addition to the use of emotion, Mary's appeal to respect for rank and justice were essential in garnering support for her cause. Mary wrote a flood of letters to Elizabeth seeking assistance over the years that she was captive in England, and they began almost as soon as Mary had arrived in the country. Mary crossed over from Scotland into Cumbria on May 16, 1568, and the very next day composed a letter to Elizabeth from Workington. The letters from the early months of Mary's imprisonment in England serve a far different function from the letters of 1565 . While Mary still believed herself the rightful queen of Scotland, her power had been officially stripped away by her own lords and further restricted by her imprisonment. With her capacity to exercise power mostly removed, Mary relied on her epistolary rhetoric in order to acquire the assistance she needed.

\section{Historical Context: Deposition and Imprisonment}

The last chapter examined letters written by Mary in 1565, when she was newly married to Robert Darnley. The queen's choice of husband was contentious, especially in England as Darnley had his own claim to the English throne through his mother, a niece 
of Henry VIII. Marriage to Darnley strengthened Mary’s own claim to the throne, making her seem to be even more of a threat to Elizabeth, who actively attempted to keep the two apart. Darnley was murdered in 1567. The year of Darnley's death Mary wed one of the men widely agreed by both contemporary sources and modern scholars to be partially responsible, James Hepburn, Earl of Bothwell. These events are key as it is the question of Mary's culpability in these events that most haunted her reputation both at the time of her marriage, as they were an important reason why her opponents forced her to abdicate, and during her imprisonment in England.

Scholars disagree on why Mary decided to wed Bothwell when his guilt in her husband's murder was almost certain. Bothwell had kidnapped Mary on the road to Edinburgh in April of 1567, taking her, with a force of 800 men, to Dunbar. Witnesses to the events when Mary petitioned for divorce from Bothwell almost a decade later confirmed that she did not go willingly. ${ }^{147}$ Retha Warnicke clearly states her belief that Bothwell sexually assaulted her at Dunbar and that the queen agreed to marry him in order to avoid further assault and to protect her honour. Warnicke supports this argument with the testimony of one of Bothwell's men, James Mellville, who was present at the kidnap and through the time Mary was held at Dunbar where he reported Bothwell raped her. ${ }^{148}$ John Guy supports the view that Mary agreed to wed Bothwell in order to secure his role as the queen's protector as she feared that attempts would be made on her life in the wake of Darnley's murder. ${ }^{149}$ Regardless of the true reason why the queen wed

\footnotetext{
${ }^{147}$ Retha Warnicke, Mary Queen of Scots (New York: Routledge, 2006), 154-153.

${ }^{148}$ Warnicke, Mary Queen of Scots, 154.

${ }^{149}$ John Guy, Queen of Scots: The True Life of Mary Stuart (New York: Mariner, 2004), 349. Guy generally dismisses the possibility of assault, but his argument is largely based on his own characterization of Mary. Guy believes it would have been completely against Mary's character to forgive Bothwell for assaulting her and that if he truly had done so, the absolute last thing she
} 
Bothwell with such haste, the already rebellious Scottish lords saw the marriage as an opportunity to lay charges upon her and have her removed from the throne.

Mary and Bothwell fled Edinburgh in June of 1567 after Mary's efforts to raise an army to assist in her defense against the Confederate Lords, the organization of the Protestant nobility. On June 15 the two sides met at Carberry Hill, but a standoff lasted most of the day. When Philibert du Croc, a French ambassador, attempted to mediate between the two sides, the Confederate Lords stated that Mary could either leave Bothwell or he could fight in single combat. ${ }^{150}$ Eventually Bothwell agreed to combat and Mary consented, but at the last moment she changed her mind and surrendered. ${ }^{151}$ Guy suggests that Mary knew that neither outcome of the battle would prove to be a true victory for her and that the Confederate Lords would not accept the outcome of the battle if Bothwell won. ${ }^{152}$ Following her surrender she was taken briefly back to Edinburgh before being transferred to Lochleven Castle where she was surrounded by those loyal to the Confederate Lords, despite a public promise by the lords that she would be allowed to remain at Holyrood. ${ }^{153}$ Mary would remain prisoner for almost a year at Lochleven.

After she had been held at Lochleven for almost a month, Mary was permitted to receive an ambassador from England. He informed her that Elizabeth wished for her release but that she would need to divorce Bothwell. Mary refused, stating that she was pregnant and could not defy her honour and bear illegitimate children. She miscarried

would have done would be to marry him (317). Guy does not mention Melville's testimony. The two primary biographical sources examined in this thesis disagree on whether Bothwell assaulted Mary, but both agree that Mary felt that she had no choice but to marry him at the time.

${ }^{150}$ Guy, Queen of Scots, 332.

${ }^{151}$ Guy, Queen of Scots, 333.

${ }^{152}$ Guy, Queen of Scots, 333.

${ }^{153}$ Warnike, Mary Queen of Scots, 162. 
twins a week later. ${ }^{154}$ On the $24^{\text {th }}$ of July Mary officially abdicated, signing away her crown in favour of her infant son, with Moray to rule for him as regent. ${ }^{155}$ Parliament officially ratified her abdication in December and the document Mary signed only discussed her physical inability to continue her reign and did not discuss Mary's Catholicism, Darnley's murder or her marriage to Bothwell, despite the fact that these were the most contentious issues of her rule. ${ }^{156}$ Mary then escaped Lochleven in May of the following year with assistance from nobles who remained loyal to her. They had managed to raise some forces in her support, and she attempted to flee to Dunbarton, where John Flemming, a loyal subject, would shelter her. ${ }^{157}$ She was unable to reach the castle due to pressure from Moray's forces and decided instead to flee to England. ${ }^{158}$ It is at this point in Mary's life when the letters examined in this chapter are written: the two months following her arrival in England. Most of the letters are written to Elizabeth, as these letters generally are Mary's own focus, but they are supplemented by letters to other important political actors.

\section{Emotion and Epistolary Rhetoric}

In discussing letters, even those of monarchs, it is nearly impossible to ignore the intervention of emotion in their creation. The role of emotion as a rhetorical strategy in

\footnotetext{
${ }^{154}$ Warnike, Mary Queen of Scots, 163.

${ }^{155}$ Guy, Queen of Scots, 352.

${ }^{156}$ James Anderson, "Four Acts of the Parliament of Scotland, Holden in December 1567, with a List of the Members present in that Parliament," in Collections Relating to the History of Mary Queen of Scotland (Edinburgh: Mosman and Brown, 1727), 208. Though this edition of documents was printed 160 years following the events of Mary's abdication, it is generally considered to be an accurate representation of the documents it presents. John Guy references the collection in a number of places in his biography, however Retha Warnicke does not provide a direct reference for Mary's abdication.

${ }^{157}$ Warnicke, Mary Queen of Scots, 165.

${ }^{158}$ Warnicke, Mary Queen of Scots, 166.
} 
Mary's letters has not received critical scrutiny. Mary's biographers have been quick to discuss tropes of emotion present in Mary's writing, but this is done in the service of creating a picture of Mary as a person, rather than as a tool for historical analysis. Mary's poetry, both genuine and counterfeit, has received some analysis of emotion. Susan Broomhall, writing specifically about Catherine de' Medici's letters to her daughter Elisabeth (Mary was intimately familiar with both women due to her time at the French court), states that emotion was an essential part of epistolary diplomacy and maintaining relationships between nobles. ${ }^{159}$ Though neither of the women in her chapter were queens regnant as Mary and Elizabeth were, their diplomatic letter writing skills were nonetheless highly valued. Broomhall argues that emotions represent "cultural-historical discourses of power," and that emotion and its presentation is often highly gendered. ${ }^{160}$ This discussion of emotion as a gendered tool of power is directly applicable to Mary's writing. Occasionally the emotion of the receipt of letters was performative, as Rayne Allinson has discussed in her assessment of the epistolary exchanges between Elizabeth and Mary, but they cannot be dismissed exclusively as performance. ${ }^{161}$ Mary often suffered from bouts of what was deemed to be 'melancholy,' which she wore an amethyst ring to counteract. These illnesses often confined her to bed and are now strongly believed to be a result of depression and stress. ${ }^{162}$ Appeals to emotion can be found

\footnotetext{
${ }^{159}$ Susan Broomhall, "Ordering Distant Affections: Fostering Love and Loyalty in the Correspondence of Catherine de' Medici to the Spanish Court, 1568-1572," in Gender and Emotions in Medieval and Early Modern Europe: Destroying Order, Structuring Disorder ed. Susan Broomhall (New York: Routledge, 2016), 67-68.

${ }^{160}$ Susan Broomhall, "Introduction," in Gender and Emotions in Medieval and Early Modern Europe: Destroying Order, Structuring Disorder ed. Susan Broomhall (New York: Routledge, 2016), 5.

${ }^{161}$ Rayne Allinson, A Monarchy of Letters: Royal Correspondence and English Diplomacy in the Reign of Elizabeth I (New York: Palgrave Macmillan, 2012), 76.

${ }^{162}$ Guy, Queen of Scots, 434.
} 
throughout Mary's letters and though she was depressed and emotional, the letters, when assessed as rhetorical documents, reveal rhetorical objectives in the emotional language.

The first letter examined in this chapter is the letter Mary wrote to Elizabeth from Workington upon her arrival in England in May of 1568. This letter is perhaps the strongest example of Mary using emotion as a way to move the recipient of her letter to action. While Strickland, who edited the letter, does not indicate whether the letters she transcribed and translated were copies, Rayne Allinson reports that the first letter Mary wrote to Elizabeth on May 18, 1568, was in Mary’s own hand. ${ }^{163}$ James Daybell emphasizes that in the early modern period, autograph letters, or letters penned by the author themselves, were considered more intimate than those written by a secretary. ${ }^{164}$ As Mary had been initially greeted respectfully, with the deputy governor of Carlisle meeting her arrival with 400 men, a secretary being available seems almost certain. ${ }^{165}$ Mary writing the letter in her own hand seems to be a choice at this moment rather than a necessity. Allinson notes that during her reign in Scotland, Mary's secretary, William Maitland, asked for the assistance of Robert Dudley in convincing Elizabeth to write to Mary in her own hand more often. ${ }^{166}$ Mary also openly complained to Thomas Randolph during her reign that her hand was far inferior to Elizabeth's. ${ }^{167}$ A precedent for the two queens writing one another autograph letters had been previously established, so while

\footnotetext{
${ }^{163}$ Allinson, A Monarchy of Letters, 83. Allinson identifies the letter as BL Cotton Caligula C, i, f. 92 .

${ }^{164}$ James Daybell, The Material Letter in Early Modern England: Manuscript Letters and the Culture and Practices of Letter-Writing, 1512-1635 (New York: Palgrave MacMillan, 2012), 86.

${ }^{165}$ Warnike, Mary Queen of Scots, 166.

${ }^{166}$ Allinson, A Monarchy of Letters, 76.

${ }^{167}$ Allinson, A Monarchy of Letters, 77.
} 
Mary writing in her own hand to Elizabeth would not have been a great surprise, the contents of the letter reinforced the personal nature of the epistle.

Mary wrote passionately about the position she now found herself in and entreated Elizabeth to send for her. Mary wrote repeatedly of God's good grace towards her as she had been rescued from a number of terrible circumstances. She wrote that it "pleased God that I should save myself from their hands," referring to the men who had murdered her secretary David Rizzio in front of her. ${ }^{168}$ Again, Mary emphasized that when she was deposed by the Scottish Lords, "it pleased God to deliver me, when they thought of putting me to death."169 Mary also reported, "God, through his infinite goodness, has preserved me, and I escaped" from her captors at Lochleven. ${ }^{170}$ These repeated references to the grace of God in her journey are unusual for Mary's letters to Elizabeth. In her letter to Elizabeth from just ten days later, there are no references to God's direct intervention in the events surrounding Mary's letter. The letter of May 27 only mentions God three times, once to "thank God" for the good friends she still possessed, ${ }^{171}$ once to give thanks that the movement against her is not gaining ground and once in offering a prayer for Elizabeth's health and long life. ${ }^{172}$ The differences in the references to God are quite stark between the two letters and the language of the earlier letter reflects more closely that of Mary's missive to her uncle, the Cardinal of Lorraine.

\footnotetext{
${ }^{168}$ Mary Stuart, Queen of Scotland, "Letter Dated May 17, 1568: The Queen of Scots to Queen Elizabeth, From Workington," in Vol. 1 of Letters of Mary Queen of Scots, ed. Agnes Strickland (London: Henry Colburn, 1842), 40.

${ }^{169}$ Mary Stuart, "Letter Dated May 17, 1568," 41.

${ }^{170}$ Mary Stuart, "Letter Dated May 17, 1568," 43.

${ }^{171}$ Mary Stuart, Queen of Scotland, "Letter dated, May 27, 1568: The Queen of Scots to Queen Elizabeth, From Carlisle," in Vol. 1 of Letters of Mary Queen of Scots, ed. Agnes Strickland (London: Henry Colburn, 1842), 47.

${ }^{172}$ Mary Stuart, "Letter dated, May 27, 1568," 48.
} 
In this letter, from June 21 of 1568, Mary proclaimed that "God tries me severely; however, rest assured that I shall die a Catholic: God will relieve me from these miseries very soon." ${ }^{173}$ While these mentions of God's intervention in her life to Mary's Catholic uncle are nowhere near as repetitive in her first letter to Elizabeth, a Protestant queen, they are certainly more similar in tone.

In both instances these references may have been used to indicate Mary's continuing belief that she remained the rightful queen of Scotland, with divine assistance. God's direct intervention in human events was widely accepted during this period, and Mary, as an anointed ruler, whose power was granted by the divine, displayed her belief in the fact that God's intervention showed divine support for her rule. This was a particularly apt argument to make because Elizabeth herself displayed an awareness of God's intervention in her own life. In her coronation pageant, Elizabeth kneeled in a prayer of thanks to God for protecting her from her enemies. ${ }^{174}$ While the concept of God intervening on behalf of the monarch would have been widely accepted by both queens' subjects, Mary used this point of similarity between the two rulers as a source of emotional connection.

The references to the divine are explicitly emotional given the circumstances of Mary's escape to England, which also would have moved Elizabeth as she had experienced similar events. Elizabeth had been imprisoned in the Tower of London by her sister, Mary Tudor, in the wake of the Wyatt rebellion. In Elizabeth's coronation pageant, before she left the Tower to continue through London, she was reported as

\footnotetext{
${ }^{173}$ Mary Stuart, "To the Cardinal of Lorraine, $21^{\text {st }}$ June, 1568," in Letters of Mary Stuart, Queen of Scotland, ed. Prince Alexander Labanoff, trans. William Turnbull, Esq. (London: Charles Dolman, 1845), 163.

${ }^{174}$ Ilona Bell, Elizabeth I: The Voice of a Monarch (New York: Palgrave Macmillan, 2010), 38.
} 
saying "I acknowledge that Thou hast dealt as wonderfully and as mercifully with me as Thou didst with Thy true and faithful servant Daniel, Thy prophet, who Thou deliveredst out of the den of the greedy and raging lions. Even so, I was overwhelmed and only by Thee delivered." ${ }^{175}$ This recollection of Elizabeth's imprisonment and following divine deliverance was printed and well publicized following her coronation and, Mary would certainly have been familiar with the events of Elizabeth's imprisonment and eventual release by her sister. The emotional climate which Mary presented in her letter would have been both familiar and perhaps moving for Elizabeth. The letter of May 17 displayed Mary's overwhelming relief at her safe arrival in England, where she believed she would find friends and allies, her divine deliverance from the enemies who imprisoned her. In her letter of May 27, Mary apologized for the haste in which she wrote her first letter, indicating that it was perhaps less carefully planned than other letters were, thus further emphasizing the emotional nature of her letter from the $17^{\text {th }} .{ }^{176}$ Allinson argues that Mary's letters to Elizabeth were often, "blurry [and] emotionally charged," supporting the idea that this letter might have been a more emotion-driven missive, with the references to God's salvation exemplary of a show of gratitude and relief which Elizabeth was sure to understand and empathize with.

The letter ends with the first instance of Mary's constant request to Elizabeth throughout her imprisonment in England. She wrote, "I entreat you to send to fetch me as soon as you possibly can, for I am in a pitiable condition, not only for a queen, but for a

\footnotetext{
${ }^{175}$ Richard Mulcaster, "The Passage of Our Most Dread Sovereign Lady, Queen Elizabeth," in Elizabeth the First and Her Age: Authoritative Texts Commentary and Criticism, eds. D. Stump and S. Fletch (New York: Norton \& Company, 2009), 38.

${ }^{176}$ Mary Stuart, “Letter dated, May 27, 1568," 45.
} 
gentlewoman." ${ }^{177}$ In this plea, Mary also attempts to appeal to the connection between the two of them as ruling monarchs. Such a focus on the two queens as intimately connected by their unique positions as women who ruled is present throughout Mary's letters to Elizabeth. Mary almost always signed her letters with a reference to the two women being sisters and their shared emotional friendship based on their shared political responsibilities. She firmly believed that Elizabeth would respond positively to her letter and expressed her anticipation for "that consolation which I expect to receive from you." ${ }^{178}$ This letter represents Mary's faith in the aid of Elizabeth in returning her to her throne in Scotland as well as her relief at having escaped immediate danger in England.

On June 21 in 1568, Mary wrote a letter to one of her Guise uncles, Charles, the Cardinal of Lorraine. Mary's correspondence with her French relatives had largely stopped after the murder of her husband, Lord Darnley. Her uncle had made a political alliance with her half-brother Moray following the death of the king, as Mary was starting to be seen as a liability to the powerful Guise family, thereby angering her. ${ }^{179}$ Now, in her time of need, her uncle was one of the closest connections Mary had to the French court in order to make appeals for assistance. Though Mary had been at the French court during the childhood of the contemporary King of France, Charles IX, he was only ten years old when Mary had returned to Scotland. Though she did write to the king in 1570 , requesting troops to be sent to England in an attempt to liberate her from English captivity, in this case Mary chose instead to write through an intermediary. ${ }^{180}$ As seen in the previous chapter, letters written directly to other sovereign rulers were less

\footnotetext{
${ }^{177}$ Mary Stuart, "Letter Dated May 17, 1568," 43-44.

178 Mary Stuart, "Letter Dated May 17, 1568," 44.

${ }^{179}$ Guy, Queen of Scots, 302.

${ }^{180}$ Warnike, Mary Queen of Scots, 193.
} 
specific about requests for aid and often contained more abstract rhetoric as a way to create and preserve diplomatic relationships. In a letter to an intermediary, in the form of a close relative, Mary could be more specific about the aid she required from a foreign court. Her uncle had been a staunch political supporter of his niece's right to rule not only Scotland, but England as well, especially after the succession of Elizabeth in $1558 .{ }^{181}$ Though their relationship had been strained, he had been Mary's mentor in political matters for most of her young life. ${ }^{182}$

Her letter is tinged with a tone of desperation from the very opening lines. Mary presented her uncle's support as the be-all-end-all of her campaign to return to her throne. While she was keen to make clear to Elizabeth that she had other options and refers to "princes" in the plural for people who might support her, she threw herself at the mercy of her uncle, saying, "if you have not pity on me now, I may say with reason that it is all over." ${ }^{183}$ She took the time to detail the situation in which she now found herself, as a prisoner in England and with little support from others in efforts to return her to her throne. She complained that though Elizabeth had sent assistance into Scotland, they were actually assisting the rebels rather than those who were still loyal to her and were effectively weakening her cause. ${ }^{184}$ She claimed that being imprisoned in England was no better than remaining at Lochleven where she had been captive in her own country. ${ }^{185}$

\footnotetext{
${ }^{181}$ Guy, Queen of Scots, 92.

${ }^{182}$ Guy, Queen of Scots, 171.

${ }^{183}$ Mary Stuart, Queen of Scotland, "To the Cardinal of Lorraine, $21^{\text {st }}$ June, 1568," in Letters of Mary Stuart, Queen of Scotland, ed. Prince Alexander Labanoff, trans. William Turnbull, Esq. (London: Charles Dolman, 1845), 162.

${ }^{184}$ Mary Stuart, "To the Cardinal of Lorraine," 162.

${ }^{185}$ Mary Stuart, "To the Cardinal of Lorraine," 162.
} 
This letter also reflects the important diplomatic work that Mary engaged in during her time at Carlisle, beyond the letter-writing campaigns for support of her cause. Messengers who were loyal subjects of Mary's were the most common way in which her letters were conveyed to London and to contacts abroad. The use of special envoys entrusted with both letters and oral instructions were often used during the period. Private messengers who were addressed in the letter as having more information were common among the nobility in England at the time and were often referenced directly in the letters they carried, to which Mary is no exception. ${ }^{186}$ Mary referenced "lord Hereis" as the bearer of her letter to Cecil from May 28, $1568 .{ }^{187}$ In the letter in question to her uncle, Mary asks him to treat her messenger Beaton well. ${ }^{188}$ By all accounts the referenced messenger was the Archbishop of Glasgow, James Beaton, who had been Mary's ambassador to France during her reign and would have been familiar not only with her uncle but with other members of the French court. ${ }^{189}$ A letter to the Archbishop was examined in the previous chapter. The letters that Mary wrote during her time in prison not only served to gain support for her cause, but also to ensure that she could continue her diplomatic work in sending loyal subjects to other rulers.

In support of her diplomatic activities, Mary often discussed the movement of loyal subjects through England to see her or to travel abroad. A central requirement of this is the issue of passports to these subjects. In her letter to her uncle, Mary stated that she had requested a French passport for George Douglas, who she was going to send to

\footnotetext{
${ }^{186}$ James Daybell, The Material Letter in Early Modern England: Manuscript Letters and the Culture and Practices of Letter Writing, 1512-1635 (New York: Palgrave MacMillan, 2012), 137.

${ }^{187}$ Mary Stuart, "Letter dated, May 28, 1568," 50.

${ }^{188}$ Mary Stuart, "To the Cardinal of Lorraine," 162.

${ }^{189}$ Warnike, Mary Queen of Scots, 102
} 
him once he was able to travel through France. ${ }^{190}$ In a letter to Elizabeth, written by Mary from Carlisle on June 26, Mary states that, "Mylord Heris wrote to me that youe would permit such of my subjects as have any business with me, to come and go with passports; but it is requisit that you should write to my Lords Scrup and Knoles, as they have refused me this; and mylord Wurkington seized, two days ago, two Scotchmen." ${ }^{191}$ Mary requested in the same letter that Elizabeth grant a passport to another of her lords as he had personal business in France and made careful note that he was not on business for her. ${ }^{192}$ The use of correspondence to secure passports or safe conduct passes was common during the period. Mary's mother, Marie de Guise, wrote to Elizabeth in order to secure a passport for Lord Seaton. De Guise suggested that the passport should be valid for a set period of time and be valid for more than one trip through Elizabeth's kingdom, conditions which remained largely the same throughout Mary's imprisonment. ${ }^{193}$ The letter to her uncle, along with letters to Elizabeth, show that Mary was still engaging in typical diplomatic processes of the period, even while she was imprisoned. Her letters not only serve as requests for assistance for herself but also for her subjects.

Mary's letter was not entirely focussed on the passage of her subjects through foreign realms. She seemed to be distraught at not only the condition in which she found herself but also at her inability to assist the subjects in Scotland that remained loyal to

\footnotetext{
${ }^{190}$ Mary Stuart, "To the Cardinal of Lorraine," 162-163.

${ }^{191}$ Mary Stuart, Queen of Scotland, "Letter dated June 26, 1568: The Queen of Scots to Queen Elizabeth," in Vol 1 of Letters of Mary Queen of Scots, ed. Agnes Strickland (London: Henry Colburn, 1842), 55-56.

${ }^{192}$ Mary Stuart, "Letter dated June 26, 1568," 57.

${ }^{193}$ Martin Lloyd, The Passport: The History of Man's Most Travelled Document (Canterbury: Queen Anne's Fan, 2016), 48.
} 
her. She wrote to her uncle that while she was captive her enemies "demolish the houses of my servants, and I cannot aid them; and hang their owners and I cannot compensate them: and yet they all remain faithful to me." 194 Mary also detailed that she had "endured injuries, calumnities, imprisonment, famine, cold, heat, flight, not knowing wither, ninety-two miles across the country without stopping or alighting, and then I have had to sleep upon the ground, and drink sour milk, and eat oatmeal without bread, and have been three nights like the owls, without a female in this country, where, to crown all, I am little else than a prisoner". ${ }^{195}$ These details which Mary provides in this letter show the dire nature of her situation. She has endured hardship as she attempted to escape, but that hardship is now for naught as she has fled one prison into another. The description of her trials is an attempt to evoke sympathy from her reader as a method of persuasion. Despite the illustration of her personal suffering, Mary's most adamant plea for assistance was not for herself but for her subjects that stayed loyal to her, begging her uncle to send assistance so that she would not have to abandon those who had supported her. ${ }^{196}$ John Guy cites Mary's reading of Erasmus during her education as the source of her desire to balance her own personal luxury with the defense of her people. ${ }^{197}$ Here again it seems her request for aid was framed more as a plea to help her assist her people rather than for a return to comfort and personal power. While Mary does request money for herself, she presents this request as being only for the mere essentials such as food, clothes and linens. ${ }^{198}$ Mary framed her emotional plea as concern for her citizens, showing that she

\footnotetext{
${ }^{194}$ Mary Stuart, "To the Cardinal of Lorraine," 164.

${ }^{195}$ Mary Stuart, "To the Cardinal of Lorraine," 163-164.

${ }^{196}$ Mary Stuart, "To the Cardinal of Lorraine," 164.

${ }^{197}$ Guy, Queen of Scots, 70.

${ }^{198}$ Mary Stuart, "To the Cardinal of Lorraine," 163.
} 
was still invested in the interests of her people as she still believed herself to be their rightful queen. In doing this Mary portrayed herself as a ruler with the best interests of her people at heart and that being unable to protect them caused her real distress. In this letter, Mary's use of emotional language is used to present her cause as being one that was noble and did not revolve around self-interest. The call to action on behalf of her people was something that was most clear in the letter to her uncle, in comparison to the letters sent to Elizabeth where Mary was more emphatic about the equal footing the women held as queens.

Attempts to move her readers to sympathy were not the only ways in which Mary used emotion in her letters. Mary wrote a letter to Elizabeth on July 5th, 1568 from Carlisle. Most significantly this letter is missing one key component which Mary included in all the other letters from this period: the address of "my good sister." Though this address, as previously discussed, is a convention of rulers writing to one another during this period, Mary made an active choice to defy convention in order to make a point to Elizabeth. This letter represents Mary's most assertive letter to Elizabeth since she had become a prisoner in England. The two and a half years Mary had spent imprisoned in England and Elizabeth's lack of action to support her were frustrating and she did not hesitate to make her displeasure known. The expressions of her anger with Elizabeth were even more explicit than in the letter of June 13, where Mary was beginning to express irritation that she still had not been sent for by Elizabeth. Mary openly stated at the beginning of the letter that, "I cannot choose (having my senses) but 
perceive very cruel sunderance in my matters." ${ }^{199}$ Mary made no attempts to conceal her disappointment and vexation in 'diplomatic' language but rather wrote plainly of what she perceived to be serious slights made against her. Mary also wrote that Elizabeth wants her to "put myself further into your country (without seeing you), and remove me farther from mine: and there to do me this dishonour at the request of my rebels, as to send commissioners to hear them against me, as you would do to a mean subject, and not hear from me by mouth."200 This open criticism of Elizabeth's handling of her situation hangs on Mary's assertion that she and Elizabeth were equals and that she was more than a "mean subject." Mary's inclusion of reminders of her rank are significant in her argument that she is being treated unfairly, as we shall see in the case of other letters in this chapter. The manner in which Mary presented her desire to be presented to Elizabeth in person showed a different facet of the emotional aspect of her rhetoric.

The emotional tone of this letter is far different from that which Mary wrote to her uncle or those that she had written to her cousin previously during her time of imprisonment. In this case the primary emotion expressed in the letter is anger. This emotional state of course makes sense logically. Mary expected to find assistance in England and instead was imprisoned. She had no chance to speak face to face with the woman who had the most opportunity to change her situation, with Mary stating that, in her view, travelling further into England without seeing Elizabeth, "I will esteem that as no favour, but will take it as the contrary: obeying it as a thing forced." ${ }^{201}$ It is only

\footnotetext{
${ }^{199}$ Mary Stuart, Queen of Scotland, "Letter dated July 5, 1568: The Queen of Scots to Queen Elizabeth," in Vol. 1 of Letters of Mary Queen of Scots, ed. Agnes Strickland (London: Henry Colburn, 1842), 58.

${ }^{200}$ Mary Stuart, "Letter dated July 5, 1568," 59.

${ }^{201}$ Mary Stuart, "Letter dated July 5, 1568," 61.
} 
natural that she was frustrated and angry at the continued imprisonment with no considerable changes to her benefit. Broomhall states that negative emotions such as anger were often used to provoke disorder, especially during times of religious or political crisis. ${ }^{202}$ This period was certainly one of crisis for Scotland and indeed for Mary, but in this case, she did not use anger to attempt to create more disorder, but rather in protest that disorder had been allowed to occur. Mary's statement about her rebels being granted more privilege than her by Elizabeth shows a belief that order had been disrupted. She expressed anger at what she sees as a disruption of the natural alliance that exists between the two rulers due to their rank and their close kinship. The dishonour that Elizabeth inflicted upon her is unjust and Mary wrote, "do with my body what you will, the honour or blame shall be yours." ${ }^{203}$ She wanted to remind Elizabeth of the consequences of her actions upon the honour of both these queens. Mary deployed emotion to show that the discord she believed Elizabeth to be sowing had the potential to cause substantial damage to the reputation of both women and possibly ruin Mary's cause for the return to her throne forever.

\section{Appeals to Rank and Kinship}

Mary's emphasis on emotion was only one rhetorical technique employed in this period. Despite her stirring letter to Elizabeth on May 17, Mary remained in England, now a prisoner. William Cecil, Elizabeth's secretary of state, had Mary placed under strict guard at Carlisle Castle, just days after her arrival. It was under these conditions that Mary wrote again to Elizabeth on May 27, ten days after her first letter. This second letter further emphasizes Mary's desire to speak to Elizabeth face to face in order to

\footnotetext{
${ }^{202}$ Broomhall, "Introduction," 1.

${ }^{203}$ Mary Stuart, "Letter dated July 5, 1568," 60.
} 
secure her support for her return to the Scottish throne. She asks to be sent for "without delay and without ceremony" which shows, as in her letter from May 17, that Mary believes that time is of the essence and that the sooner she sees Elizabeth face to face, the better. ${ }^{204}$ Mary believes that, though she has been moved from Workington to Carlisle and is now under close watch, meeting Elizabeth face to face is still her best hope of gaining her cousin's support. In this letter, however, Mary is far more strategic in the way she attempts to solicit assistance from Elizabeth.

Mary made a number of statements in this letter that are intended to remind Elizabeth of her responsibilities to her ally and peer. In the beginning of the letter, when Mary emphasized her desire to discuss what has happened to her with Elizabeth directly and she stated that she wishes to do so in view of their "near relationship, equality of rank, and professed friendship." ${ }^{205}$ This statement served to remind Elizabeth of the duties she has to Mary as kin, as a fellow queen and as a friend. Ideas of close kinship were used by both women in their letters to one another throughout Mary's reign in Scotland, as seen in the previous chapter. Though the call to kinship was often a convention used in letters between rulers, as discussed in chapter one, Mary would purposefully choose to omit that convention in her letter from July 5 of the same year, which we will see later in this chapter. Mary needed to remind Elizabeth of these duties in order to push her to act in her favour. She also reminded Elizabeth that rulers are expected to assist one another. ${ }^{206}$ Mary believed this close relationship between the two

\footnotetext{
${ }^{204}$ Mary Stuart, "Letter dated, May 27, 1568," 46.

${ }^{205}$ Mary Stuart, "Letter dated, May 27, 1568," 45.

${ }^{206}$ Mary Stuart, "Letter dated, May 27, 1568," 46.
} 
queens, and their equal rank, meant that Elizabeth is the person she should ultimately be making her case to.

Following Mary's composition of her letter to Elizabeth on May 28, she wrote a short note to William Cecil, the man largely responsible for her imprisonment at Carlisle. Mary's relationship with her cousin's closest counsellor was fraught with conflict. Cecil, from early on in his position as Secretary of State for Elizabeth saw Mary as a threat to his mistress's reign and believed the best way to protect Elizabeth was to support the protestant Scottish lords. A document entitled "A memorial of certain points meet for restoring the realm of Scotland to the ancient weal," written in August of 1559, has been attributed to Cecil by one of his biographers, Stephen Alford. ${ }^{207}$ The document suggested that Scotland should become Protestant and it should either make permanent peace with England or unite the crowns of the two countries. The proposal also suggested that if Mary, reigning in France with Francis II at the time, had opposition to the proposal then she ought to be deposed and the crown pass to the next in succession to the throne. ${ }^{208}$ Early in Elizabeth's reign, Cecil took a strong negative stance towards Mary and the reign of a Catholic monarch in Scotland. Cecil's view of Mary was fueled by his belief that she was a threat to Elizabeth and the security of her reign. Lady Catherine Gray, considered by some to be Elizabeth's strongest possible successor, had died a few months before Mary's imprisonment, making Mary an even stronger contender for the throne. ${ }^{209}$ Mary's presence in Scotland prompted Cecil to draft a memorandum with possible

\footnotetext{
${ }^{207}$ Stephen Alford, Burghley: William Cecil at the Court of Elizabeth I (New Haven: Yale University Press, 2008), 107

${ }^{208}$ Alford, Burghley, 107.

${ }^{209}$ Kristen Post Walton, Catholic Queen, Protestant Patriarchy: Mary, Queen of Scots, and the Politics of Gender and Religion (New York: Palgrave Macmillan, 2007), 164.
} 
resolutions of the matter for Elizabeth: to send Mary back to Scotland, to keep her prisoner, or to send her on to France. ${ }^{210}$ Cecil understood the significance of the threat of Mary in Elizabeth's territory and needed to advise his mistress on what she should do.

This letter to Cecil is fascinating as it shows Mary writing to a man who is below her in rank but who still held a tremendous amount of power over her. Here too, Mary wrote in the hope that his counsel to Elizabeth could be tipped in her favour and she might be granted the assistance she needed. Mary was attempting to strike a balance between the exercise of her own power as a monarch, which she believed she still possessed, and writing to the man responsible for her imprisonment. ${ }^{211}$ The letter is short but reveals Mary's awareness of Cecil's involvement in her situation. She described Cecil as a "friend to equity" 212 which she says necessitated that she seek his advice in pursuit of her "just cause". ${ }^{213}$ She also states that the good service he has provided to Elizabeth has motivated her to believe that she should be asking for his counsel. ${ }^{214}$ Mary knew that while Elizabeth is her best chance for assistance, she needed to also have Cecil on her side as he was Elizabeth's most important advisor. She was surely aware of Cecil's distaste for her, seeing her as a threat to the reign of his mistress, but she wrote to him regardless. There is also an emphasis on her rank in this short note. She stated that Cecil owed the good service he had provided to Elizabeth, "consequently all those who are of her blood and of like dignity," strongly implying that as she was Elizabeth's kin, she was

\footnotetext{
${ }^{210}$ Post Walton, Catholic Queen, Protestant Patriarchy, 165.

${ }^{211}$ Guy, Queen of Scots, 357.

${ }^{212}$ Mary Stuart, Queen of Scotland, "Letter dated, May 28, 1568: The Queen of Scots to Sir W. Cecil, afterwards Lord Burleigh," in Vol. 1 of Letters of Mary Queen of Scots, ed. Agnes Strickland. (London: Henry Colburn, 1842), 49.

${ }^{213}$ Mary Stuart, "Letter dated, May 28, 1568," 50.

${ }^{214}$ Mary Stuart, "Letter dated, May 28, 1568," 49.
} 
owed loyalty. ${ }^{215}$ Though Cecil, at the time, had some physical control over the exiled queen, she reminded him that she is still a queen. Mary placing emphasis on her rank, given the history between them, reads much like a warning in between compliments. Here, Mary is nothing if not direct. She followed the appropriate conventions of a letter, wishing him and his wife good health, but her establishment of her rank is clear. ${ }^{216}$ One of the essential difficulties of Mary's presence in England is that Elizabeth wished to respect Mary's rank because to do otherwise might have been read as support for her deposition, which could threaten her own authority. ${ }^{217}$

Mary wrote to Elizabeth again on June 13. At this time Mary had been in England for nearly a month and was still being held at Carlisle. Her frustration was becoming clear in her letters. Here, Mary does not emphasize meeting with Elizabeth as her prime goal. She once again reinforced both that her present position should be of "importance to all princes" but also that Elizabeth should be especially concerned as Mary had "the honour of being so near of kin to you."218 She also stated that she believes that any councillors who would dissuade her from hearing her case are incorrect to advise her this way asking, "did you ever hear a prince censured for listening in person to the complaints of those who complain that they have been falsely accused?"219 In the middle of her letter Mary wrote rather accusatory statements directed towards Elizabeth. She described her hope that Elizabeth would be quick to assist her and restore her to the throne. Mary then

\footnotetext{
${ }^{215}$ Mary Stuart, "Letter dated, May 28, 1568," 49.

${ }^{216}$ Mary Stuart, "Letter dated, May 28, 1568," 50.

${ }^{217}$ Walton, Catholic Queen, 164.

${ }^{218}$ Mary Stuart, Queen of Scotland, "Letter dated, June 13, 1568: The Queen of Scots to Queen Elizabeth," in Vol. 1 of Letters of Mary Queen of Scots, ed. Agnes Strickland (London: Henry Colburn, 1842), 50.

${ }^{219}$ Mary Stuart, "Letter dated, June 13, 1568," 50.
} 
said she had been mistaken to believe that. ${ }^{220}$ This frank expression of disappointment in Elizabeth is another example of Mary's occasional use of an openly accusatory tone in letters to Elizabeth. ${ }^{221}$ Mary also expressed her disappointment that Elizabeth had granted the Earl of Moray, her half-brother and the leader of the rebels against her, an audience when she had consistently refused Mary that opportunity. ${ }^{222}$ She stated that her rebels have no right to put her on trial, and for a queen to answer to them in such a manner would be in defiance of her station. ${ }^{223}$ Mary was now emphasizing her rank overtly and the rights that she possessed. This emphasis on her position as monarch is essential as Mary lacked many of the concrete political powers which she had possessed as queen in the letters examined in the previous chapter and thus her letters were one of the only ways for her to exert political influence in accordance with her position. In this letter, Mary chastised Elizabeth for her treatment of her as a fellow queen.

Mary not only emphasized her rights as a ruler but also expressed that she believed her current imprisonment was unjust. Mary openly stated that since she was innocent, Elizabeth was wrong to keep her imprisoned, just as the Protestant nobles had done. ${ }^{224}$ Stating that her imprisonment is an injustice is an open slight to Elizabeth's choice on how to handle this foreign queen in her country. Though Mary said she did not blame Elizabeth for the poor treatment of her, but rather her advisors, the accusations still stand for themselves and there was clear judgement on Mary's part that Elizabeth has allowed herself to be advised to treat a fellow ruler poorly. ${ }^{225}$ She stated that Elizabeth

${ }^{220}$ Mary Stuart, "Letter dated, June 13, 1568," 51.

${ }^{221}$ Rayne Allinson, A Monarchy of Letters, 74.

${ }^{222}$ Mary Stuart, "Letter dated, June 13, 1568," 52-53.

${ }^{223}$ Mary Stuart, "Letter dated, June 13, 1568," 53.

${ }^{224}$ Mary Stuart, "Letter dated, June 13, 1568," 52.

${ }^{225}$ Mary Stuart, "Letter dated, June 13, 1568," 54. 
might fear blame from others if she were to grant Mary an audience but if that was the case, Elizabeth should simply allow her to travel to the continent and seek assistance from other rulers. ${ }^{226}$ At this point in her imprisonment however, the French ambassador in England had been assured that Mary, also a dowager queen of France, was being given all the appropriate accommodations to her rank, in an attempt to prevent hostilities on the part of the French. ${ }^{227}$ While Mary believed she might have better luck with her French relatives, the English were determined to keep her on the island for at least a little while longer.

\section{Requests for Justice}

Mary did not solely rely on appeals to the rights of her rank or kinship ties in order to move her readers in these letters. Cristy Beemer discusses the renaissance idea of kairos, applying it to letters written both by Elizabeth and by Mary, both at times when they were in vulnerable positions. The technique of kairos is defined as being the use of a particular moment in time in order to further one's goal in the authorship of a text.

Beemer also notes that "precise moment of the letter's composition — the sophistic kairos as a 'point in time' - affects the rhetorical strategy of the author." ${ }^{228}$ Mary was acutely aware of the significance of the moment in which she resides. She had temporarily, she believed, kept herself safe from her own nobles, but she needed to move quickly in order to secure support for her return to the throne. When Mary arrived in England, the first letter she wrote was to Elizabeth. ${ }^{229}$ Mary knew that she needed to secure Elizabeth's

\footnotetext{
${ }^{226}$ Mary Stuart, "Letter dated, June 13, 1568," 53.

${ }^{227}$ Walton, Catholic Queen, 165. Original: William Cecil, "Considerations on Mary, Queen of Scots, coming into England" British Library, Sloane MS 3199, ff. 39-41.

${ }^{228}$ Beemer, "God Save the Queen," 76.

${ }^{229}$ Guy, Queen of Scots, 357.
} 
support as soon as possible and this urgency is reflected in her letter. Mary noted that Elizabeth should send for her "as soon as [she] possibly can," emphasizing to her fellow queen that time is of the essence. ${ }^{230}$ Emphasizing that Mary needed Elizabeth's aid as soon as possible was only one of the strategies Mary used in her letters to seek assistance.

The overall purpose of Mary's letter of May 17 to Elizabeth was to prove that the charges made against her, leading to the abdication of her throne and her imprisonment by her nobles, were not valid and to attempt to persuade Elizabeth to send for her. This letter to Elizabeth, though coloured by the emotional relief of her escape, nonetheless follows a logical structure. The events leading up to her forced abdication are presented in chronological order from the murder of her secretary David Rizzio in 1566 all the way through to her escape. There are, however, conspicuous absences in her narrative. Perhaps the two most contentious events of her reign are missing: Darnley's murder and her marriage to Bothwell. Given the importance of these two events, logically it seems that Mary would feel it necessary to address them in detail. Certainly, the history between the two women on Mary's choice of husband was already deeply fraught. Elizabeth had advised Mary on who might be a suitable husband and had even suggested Robert Dudley, one of her own suitors, as a choice, but Mary chose to wed Darnley instead, frustrating Elizabeth as this strengthened Mary's claim to the English throne. ${ }^{231}$ The absence of her mention of the marriage to Bothwell likely stems from her knowledge of Elizabeth's disapproval that Bothwell was not brought to justice over his involvement in Darnley's death. In a letter to Mary in February of 1567, Elizabeth counselled her, "to take this thing so much to heart that you will not fear to touch even him whom you have

\footnotetext{
${ }^{230}$ Mary Stuart, "Letter Dated May 17, 1568," 43.

${ }^{231}$ Allinson, A Monarchy of Letters, 76.
} 
nearest to you." ${ }^{232}$ Even more explicitly Elizabeth advises against marrying Bothwell in 1567 , stating that since he was already married, the union would not be lawful either in the eyes of the state or of God. Elizabeth also stated in this letter that she felt assured that Mary's supposed involvement in the murder of Darnley was false. ${ }^{233}$ Mary already knew Elizabeth's opinions on the charges that were most prominent in the case for her deposition. Mary's letter, though discussing events from years previously, shows itself as one letter in an established relationship of correspondence between the two women, as Mary felt no need to discuss the most prominent charges of her rebels.

Mary, instead of discussing the charges that were most contentious, and were generally already settled between the two women, attempted to villainize the Protestant lords who had rebelled against her, in order to convince Elizabeth of the just nature of her cause. Mary noted that her lords claimed that she was falling victim to bad counsel, a charge which she stated she believed herself to be innocent of. ${ }^{234}$ Her proof for her innocence relied on the fact that she willingly went to her nobles after surrendering at Carberry Hill, telling them she would reform anything they wished, which resulted in her imprisonment. ${ }^{235}$ Mary presented her actions as being generous and co-operative with the nobles, attempting to disprove any claim that their aggression towards her was warranted. Mary claimed that her nobles "threatened to kill me if I did not sign an abdication of my

\footnotetext{
${ }^{232}$ Elizabeth Tudor, Queen of England, "Queen Elizabeth to Mary, Queen of Scots, February 24, 1567," in Elizabeth I: Collected Works, ed. L. S. Marcus, J. Mueller and M. B. Rose (Chicago, University of Chicago Press: 2000), 116. The edited edition of Elizabeth's works identifies "him whom you have nearest to you" to be Bothwell.

${ }^{233}$ Elizabeth Tudor, Queen of England, "Queen Elizabeth to Mary, Queen of Scots, June 23, 1567," in Elizabeth I: Collected Works, ed. L. S. Marcus, J. Mueller and M. B. Rose (Chicago, University of Chicago Press: 2000), 118.

${ }^{234}$ Mary Stuart, "Letter Dated May 17, 1568," 40.

${ }^{235}$ Mary Stuart, "Letter Dated May 17, 1568," 41.
} 
crown, which the fear of immediate death caused me to do." 236 Scholars generally agree that Mary was likely threatened to obtain her signature on the declaration of her abdication. ${ }^{237}$ In the letter, Mary presented herself as open and receptive to the criticism of the nobles who had aligned themselves against her. She claims that she had requested a parliament to be held twice after her abdication "for the purpose of reforming every thing," and that she proposed to allow the lords who had rebelled against her "to return to their duty, and to offer them security of their lives and estates." ${ }^{238}$ In response, Mary stated that the rebels imprisoned the messengers who carried these pleas and declared it treason to support her. ${ }^{239}$ Mary was presenting the nobles aligned against her as having a personal vendetta against her rather than genuine irreconcilable political beliefs and trying to isolate her from any supporters. She also claimed to have been denied smaller, more reasonable requests, like the safe passage of Lord Robert Boyd to Lochleven. ${ }^{240}$ Through the presentation of these events in her letter, Mary attempted to prove to Elizabeth that her treatment was not warranted and tried to convince Elizabeth to assist her as a fellow monarch.

In the letter to Elizabeth from Carlisle on May 27, Mary made statements about injustices committed against her and that this time it was Elizabeth, rather than her own nobles, who was acting unjustly. Mary stated that there was, "nothing to prevent me from applying to [other princes] but this detention, which, to speak freely to you as you do to me, I think rather harsh and strange, considering that I came so frankly into your country

\footnotetext{
${ }^{236}$ Mary Stuart, "Letter Dated May 17, 1568," 41.

${ }^{237}$ Guy, Queen of Scots, 352-353. Warnike, Mary Queen of Scots, 164.

${ }^{238}$ Mary Stuart, "Letter Dated May 17, 1568," 42.

${ }^{239}$ Mary Stuart, "Letter Dated May 17, 1568," 42.

${ }^{240}$ Mary Stuart, "Letter Dated May 17, 1568," 42.
} 
without any condition or any distrust of your friendship."241 Though Mary, in the letter of May 17, expresses a distaste for her current state of imprisonment, she is not adamant that the imprisonment is unjust until this letter from more than a week later. The focus is more on her "just cause," as she wrote in her letter to Cecil, rather than on her detention. ${ }^{242}$ Though this letter to Elizabeth represents a large show of impatience upon Mary's part it is also revealing that Mary is attempting to lean on Elizabeth and encourage her to act.

Mary's tactics in this letter also show distinct changes from previous examples. Instead of emphasizing that Elizabeth is her only option, she made plain that her other options had become more favourable and encouraged Elizabeth to either act or allow her to leave England and seek assistance elsewhere. Mary was still willing to talk to Elizabeth in order to secure her aid, but Elizabeth's delay was making her impatient, and with good reason. Mary knew that time was not on her side and urged Elizabeth to make a choice, stating, "I beseech you, assist me, binding me to you in every thing, or be neuter. And permit me to try what I can do elsewhere, otherwise, by delaying matters, you will injure me more than my very enemies."243 Mary was getting desperate for something to be done, she knew that she needed to gather support as quickly as possible. This sense of urgency in the letter shows kairos at work again in Mary's writing: an attempt to emphasize the importance of time and the present moment. In this letter, however, it is far more explicit. Mary insists that her concern is not only for herself but for her subjects who remain loyal to her, telling Elizabeth that staying captive will cause

\footnotetext{
${ }^{241}$ Mary Stuart, "Letter dated, May 27, 1568," 47.

${ }^{242}$ Mary Stuart, "Letter dated, May 28, 1568," 50.
}

${ }^{243}$ Mary Stuart, "Letter dated, June 13, 1568," 53. 
them to become subject to further attacks from the rebels. ${ }^{244}$ Additionally, at the conclusion of the letter, Mary asked that her subjects be allowed access to her in order to bring her intelligence about the Protestant lords and their activities in Scotland as she has been "detained for so long without any certainty." 245 Mary became more explicit in her desire to be removed from captivity and her growing urgency becomes a more prominent feature in this letter. Mary presented her imprisonment and Elizabeth's lack of action as unjust in order to urge her to take action in her cousin's favour.

The letters examined in this chapter exemplify the unusual position in which Mary found herself in 1568 . She knew that she was still by all rights a true queen, and yet she was prevented from exercising her authority. She knew her cause was just, but the greatest potential ally she had, Elizabeth, was not acting. These letters were among the only ways Mary could take assertive action both personally and politically during this period. Mary injected a substantial amount of emotion into her writing of this period, hoping to move her correspondents to sympathize with her plight and the hardships she had suffered, or to stir them into action on her behalf. Despite the fact that she had been deposed, Mary often placed focus on her rank as a monarch, both to Elizabeth and William Cecil. Mary stressed that since she was innocent of the charges made against her by the Scottish rebels, she still was owed the privileges of a queen. The advantages due to a queen were emphasised as being particularly important to Elizabeth as she and her cousin were not only kin but women in the position of ruler, thus Elizabeth should have a strong interest in supporting Mary's rights as a queen. In addition to a focus on rank, the idea that Mary was the victim of injustice is strongly emphasized in her letters. In the

\footnotetext{
${ }^{244}$ Mary Stuart, "Letter dated, June 13, 1568," 52.

${ }^{245}$ Mary Stuart, "Letter dated, June 13, 1568," 54.
} 
next chapter we will see Mary further emphasizing the image of herself as a queen who is a victim of offense to her rank surrounding the inquiry into her culpability in the murder of Robert Darnley and the investigation into the Casket Letters. 


\section{Chapter Three: A Persecuted Prince in the Casket Inquiry}

The letters and formal statement examined in this chapter were written just a few months after those in the previous chapter. At this point, Mary was still imprisoned in England, her requests to be sent for by Elizabeth having gone unanswered. The chapter will focus on the manner in which Mary used letters, as well as a single formal statement, as part of her efforts during the inquiry into the Casket Letters to ensure that the proceedings would end in her favour and not that of the rebels. The examination of the documents in this chapter will show Mary's flexibility in rhetorical strategy based on her audience and circumstance, proving her to be a capable rhetorician in the face of many challenges. She could produce a logical treatise, she could appeal to loyalty, kinship, and friendship and represent herself as a suffering queen, subject to undue persecution. Mary employed these strategies with the goal of attempting to ensure she did not allow the proceedings to favour her rebels. The investigation into these letters threatened Mary as her rebel lords were attempting to present them as evidence that she was culpable in the murder of Robert Darnley. As the inquiry transitioned from an impartial arbitration on the relationship between the Confederate Lords and their deposed queen to a trial for Mary's complicity in her husband's murder, Mary needed to assert her authority as sovereign and appeal to those around her for assistance. Though she appealed to friendship and loyalty to gain support, Mary was also able to present cogent legal arguments to support her interests. This chapter will also introduce the notion of Mary's presentation of herself as a suffering and persecuted rightful monarch. This image of Mary would be further amplified later in her imprisonment and even after her death, but this chapter will show 
the beginnings of this image as Mary faced what she believed were unfounded accusations.

It is important to note that this chapter will not attempt to assess the authenticity of the Casket Letters themselves. John Guy asserted that while some portions of the letters might have genuinely been written by Mary, a large majority of incriminating sections were forged, backdated or otherwise altered. Guy argues that none of them positively establish Mary’s guilt in Darnley's death. The Casket letters were supposed to have been written more than a year prior to her imprisonment in England, which sets them outside the period being examined. It is important to note that the originals of the Casket letters do not survive. The copies closest to the French originals are the English translations and transcriptions made for English judges of the inquiry. Though there is no evidence as to the cause of their disappearance, Guy believes the originals were purposefully destroyed as James VI was nearing eighteen at the time the letters disappeared and he wished to protect the reputation of his family. ${ }^{246}$ Regardless of the authenticity of the Casket letters, Mary's authentic letters and other written reactions to the proceedings are the focus of this chapter. Mary's chances of returning to Scotland as queen hung on the English government's ruling about whether the Casket letters were genuine as Mary remained a prisoner in England. The manner in which she handled the inquiry into these letters was important if she wanted to return to her throne with the assistance of Elizabeth.

\footnotetext{
${ }^{246}$ John Guy, Queen of Scots: The True Life of Mary Stuart (New York: Mariner, 2005), 386. Guy has undertaken the most significant modern investigation into the letters for his book, Queen of Scots: The True Life of Mary Stuart
} 
The documents examined in this chapter are significant as they show Mary's rhetorical reactions to the proceedings of the Casket inquiry, one of the most significant challenges Mary faced while imprisoned in England. Focusing on Mary's rhetorical flexibility in this time of crisis challenges traditional narratives that Mary was incompetent, naive or out of touch. These documents show that Mary was aware of the strategies that would best support her interests with the audience of each text.

\section{The Casket Letters: Discovery and Initial Examination}

The mystery of the Casket letters began when Mary was still imprisoned in Lochleven in Scotland. In the 1567 parliament, the Scottish Confederate Lords justified taking up arms against their queen by stating that prior to the Battle of Carberry Hill, they had found evidence that Mary was implicated in Darnley's murder. ${ }^{247}$ The evidence they were referencing was, of course, the letters that the lords would later claim were found in a silver gilt chest at Holyrood. In an initial investigation into the letters however, the Earl of Morton testified to Elizabeth and Cecil that the letters had only been discovered after Mary had been taken captive at Carberry Hill. An informant had notified him that three of Bothwell's servants had entered the castle in Edinburgh. One of these servants confessed under torture that he had taken a silver casket from Bothwell's rooms, which the lords then broke open to reveal the letters, marriage contracts and poems that would serve as evidence of Mary's culpability in Darnley's murder and her adulterous relationship with Bothwell. ${ }^{248}$ These documents would serve as proof that the lord's rebellion and the deposition of an anointed queen was valid, not treasonous.

\footnotetext{
${ }^{247}$ Guy, Queen of Scots, 385.
}

${ }^{248}$ Guy, Queen of Scots, 385. 
During the time Mary was imprisoned in Lochleven, the Confederate Lords began to compile evidence against her, including the documents in the silver casket, in order to justify Mary's forced abdication and capture, prompted by William Cecil's request for evidence of wrongdoing from the lords on behalf of Elizabeth. ${ }^{249}$ Cecil was deeply suspicious of Mary due to her claim to the English throne and her repeated requests for Elizabeth to name her heir to the English throne. Despite Cecil's wariness, Elizabeth was outraged at the deposition of an anointed queen as it was an affront against the sovereignty of a monarch ordained by God. As a result of Elizabeth's anger at the rebellion in Scotland Cecil knew that Mary had a chance at persuading his mistress to assist her in returning to the Scottish throne. ${ }^{250}$ Cecil saw the evidence compiled by the lords as an opportunity to assist the rebels in ensuring Mary would not return as queen without angering his mistress. The man charged with the creation of the dossier against Mary was George Buchanan. Mary had previously been a patron of Buchanan, commissioning him to create the entertainments at the baptism of Prince James. ${ }^{251}$ Buchanan was not only close to the Earl of Moray, but had also been born and educated in Lennox territory, giving him a stronger loyalty to the deceased Darnley, whose father was the Earl of Lennox, than to Mary. ${ }^{252}$ The Confederate Lords knew that they had little power over their deposed queen while she was imprisoned in England. William Cecil examined the documents presented by Moray at length. The materials gathered by Buchanan, including copies of the sonnets, contracts and letters, were sent to Cecil in

\footnotetext{
${ }^{249}$ Guy, Queen of Scots, 375.

${ }^{250}$ Stephen Alford, Burghley: William Cecil at the Court of Elizabeth I (New Haven: Yale University Press, 2008), 151.

${ }^{251}$ Guy, Queen of Scots, 374.

${ }^{252}$ Guy, Queen of Scots, 374.
} 
June 1568 , less than a month after Mary escaped to Carlisle. ${ }^{253}$ Though Mary had thrown herself on the mercy of her English cousin, Cecil was determined to examine the evidence of the charges against her.

Cecil's personal examination of the documents began the process of investigating the evidence against Mary. The marriage contracts and poems said to have been contained in the casket were dismissed almost immediately. Cecil instead focused his inquiry on the letters. ${ }^{254}$ Guy argues that the sonnets were not genuinely written by Mary. His assertion is that the poems were far too clumsily written for a native French speaker, as Mary was, and they do not appear to be genuine when compared to the poetry known to have been written by Mary. ${ }^{255}$ Robin Bell, on the other hand, in his edition of Mary's poems published in 1992, states his belief that the poems are genuine, if misdated, still acknowledging that they may have been tampered with. He states that the sonnets adhere to “Mary's characteristic, slightly unorthodox syntax and her wordgames, puns, sideways leaps in thought and conventional piety mixed with deep emotion." ${ }^{256}$ Jessica DeVos argues that the conventions of the poems align with Mary's interest in Italian Renaissance poetry and thus it is certainly possible that the sonnets were genuine but that the poems were not autobiographical but artistic. DeVos states that the use of the first person within the poems does not implicate Mary's guilt in adultery by describing her affair with Bothwell, but rather showed Mary's interest in both classical and renaissance poetry. ${ }^{257}$

\footnotetext{
${ }^{253}$ Guy, Queen of Scots, 403.

${ }^{254}$ Guy, Queen of Scots, 389.

${ }^{255}$ Guy, Queen of Scots, 387. Note that Guy does not cite specific authors for this assertion.

${ }^{256}$ Robin Bell, Bittersweet Within My Heart: The Love Poems of Mary, Queen of Scots (San Francisco: Chronicle Books, 1992), 29.

${ }^{257}$ Jessica DeVos, “Authenticity, Artifice, and Ovid's Heroides in Mary Stuart's Casket Sonnets," French Studies 71, no. 4 (2017): 507.
} 
Regardless of whether they were genuine or not, the poems were not examined as potential evidence against Mary at the time of the inquiry. The two marriage contracts were also disregarded. One of the contracts is an obvious forgery as it references events that occurred well after the supposed date it was written. ${ }^{258}$ The second marriage contract may have been genuine but as it calls Darnley Mary's "late husband," it could only have been written after his death and thus did not prove Mary's culpability in Darnley's murder. Despite the fact that this document was undated, Moray claimed it had been written before Darnley's death, which was generally thought to be unconvincing. ${ }^{259}$ Having discounted the sonnets and the contracts, Cecil knew the case against Mary hinged on the letters and turned his attention to them.

\section{The Casket Letters: The Formal Inquiry}

Between May and September of 1568, Strickland records twelve letters written from Mary to Elizabeth, during which time Mary had been moved from Workington to Carlisle and then to Bolton. In the autumn of 1568, the examination of the evidence against Mary became further formalized. Cecil convinced Elizabeth that a formal inquiry was necessary in order to examine the Casket letters and their credibility. The inquiry would be framed as an impartial arbitration between Mary and her rebellious subjects. Elizabeth and the English lords acting in her name would serve as mediators. ${ }^{260} \mathrm{~T} . \mathrm{F}$. Henderson, whose work on the Casket letters was widely considered definitive until Guy's re-examination, reported that the purpose of the conference was not seen as a court to convict Mary, but rather was presented as an attempt to "bring about a modus vivendi,

\footnotetext{
${ }^{258}$ Guy, Queen of Scots, 388.

${ }^{259}$ Guy, Queen of Scots, 388-389.

${ }^{260}$ Guy, Queen of Scots, 416.
} 
not only as between Elizabeth and the Confederate Lords of Scotland, but, if possible, between the Queen of Scots and them." ${ }^{261}$ Henderson is not clear as to the nature of this type of compromise but the implication is that the examination of the Casket Letters would release Mary from the liminal position of a prisoner either by proving her guilt or innocence. Through this careful framing, the questionable legality of a criminal trial of the monarch of a foreign nation was carefully sidestepped by Cecil and Elizabeth.

The inquiry formally began on October 4, 1568 at York. Initially, Moray did not produce the letters as official evidence but did present them to the judges privately. He wanted to protect his interests and feared that if he levelled charges of murder and adultery without being able to prove them, Elizabeth might not recognize his regency. ${ }^{262}$ Guy acknowledges that not only did Cecil and Moray understand the shaky nature of the evidence they were presenting, with the latter likely being at least complicit in the forgery of some of these documents, but the judges appointed to the conference were doubtful of the legitimacy of the letters. ${ }^{263}$ It was at this point that Cecil knew the inquiry was not going his way. He saw the distinct possibility that the letters might sway the council in Mary's favour. All of the appointed judges knew that some of Mary's accusers from the Confederate Lords were themselves complicit in Darnley's murder, making their accusations appear shaky and to be a mere personal vendetta against their deposed queen. Cecil had the trial temporarily adjourned and moved to Westminster. When it convened again on November $26^{\text {th }}$, five additional judges were appointed, including Cecil himself and his brother-in-law, in order to tip the court in Moray's favour. ${ }^{264}$ While Henderson

${ }^{261}$ T. F. Henderson, The Casket Letters and Mary Queen of Scots (Edinburgh, 1890), 29.

${ }^{262}$ Guy, Queen of Scots, 417.

${ }^{263}$ Guy, Queen of Scots, 418.

${ }^{264}$ Guy, Queen of Scots, 418. 
declined to comment on the question of whether the trial was fair, Guy believes that Cecil used the trial to ensure that Mary was no longer a threat to Elizabeth's reign by ensuring that charges of murder and adultery would have substantial evidence. If Mary was found guilty on these charges it would justify her deposition and eliminate support for her in England and Scotland. ${ }^{265}$ In addition to Guy, Cecil's most respected modern biographer, Stephen Alford, agrees that Cecil was deliberately trying to favour Mary's enemies by appointing himself as one of the new commissioners. ${ }^{266}$ Generally there is agreement among scholars that the trial was a piece of political theatre intended to defame and discredit Mary.

Cecil convinced Elizabeth to give Moray some of the assurances he needed. Elizabeth told Moray that if the letters were found to contain strong evidence of Mary's complicity in the murder she would either be returned to the Lords in captivity or held in England and she would recognize his regency. At this point Moray formally brought forward the charge of murder. ${ }^{267}$ Mary was angered by this abrupt change of strategy. Moray's charge of murder meant the proceedings were now a trial, and on December 6 Mary ordered her advocates to withdraw. The next day Moray formally presented the Casket Letters as evidence in the trial, meaning Mary's advocates were unable to claim the documents were forgeries or did not belong to the queen. ${ }^{268}$ After the initial examination of the letters Elizabeth found the trial too one-sided and began to exert her control over Cecil. She adjourned the tribunal again, added more judges, and presided over the proceedings herself when they were moved to Hampton Court. The second

\footnotetext{
${ }^{265}$ Henderson, The Casket Letters and Mary Queen of Scots, 28.

${ }^{266}$ Alford, Burghley, 152.

${ }^{267}$ Guy, Queen of Scots, 418.

${ }^{268}$ Guy, Queen of Scots, 418.
} 
official examination of the letters began on the $14^{\text {th }}$ of December. ${ }^{269}$ By Christmas, Elizabeth, seeing that the trial had been prejudiced against Mary, who had refused to answer the charges unless she appeared in person in front of the committee, adjourned the inquiry indefinitely, as she still did not wish to see the Scottish queen in person at the trial. ${ }^{270}$ Cecil issued a statement on Elizabeth's behalf on January $10^{\text {th }}$ of the new year stating nothing had been proven sufficiently against either Mary or Moray. ${ }^{271}$ Ultimately the inquiry into the Casket Letters decided very little. Mary remained a prisoner in England.

\section{Mary's Letters in Response to the Inquiry}

Mary's reaction to the inquiry has largely gone unexamined. Retha Warnicke references a 1569 letter from Mary, to Elizabeth, assuring the English queen that even if she had similar thoughts to those contained in the Casket Letters, she would have never put them in writing. ${ }^{272}$ The statement reported by Labanoff as being given in front of the conference on the Casket Letters has also gone relatively unexamined. These letters and the statement are valuable sources as they show Mary attempting to participate in proving her own innocence without being allowed to attend the sessions herself. Due to the manner in which the inquiry progressed, Mary had no other choice but to put her faith in her councillors to defend her against the accusations of her rebels. Letters and the statement to the court were the only way Mary was able to influence the proceedings, and

\footnotetext{
${ }^{269}$ Guy, Queen of Scots, 419-420.

${ }^{270}$ Guy, Queen of Scots, 422.

${ }^{271}$ Retha Warnicke, Mary Queen of Scots (New York: Routledge, 2006), 184-185.

${ }^{272}$ Warnicke, Mary Queen of Scots, 175. Warnicke provides no reference to the location of this letter in her notes.
} 
thus they are a valuable source for showing how she attempted to manage the controversial conference.

The first letter was written on October 22, not long after the beginning of the inquiry. Mary addressed the short note, written to a Monsieur de la Forest, who is said to be one of the ambassadors of Mary's "good brother," the king of France. ${ }^{273}$ The letter is significant because it shows that Mary initially had faith in the proceedings as a genuine attempt on Elizabeth's part to mediate between Mary and her subjects. Additionally, the letter shows Mary drawing on her political allies, using the language of friendship and affection in order to assist in procuring their assistance in the inquiry. Mary's employment of the language of affection and friendship was an important tool of diplomatic correspondence, as we have seen previously.

Towards the beginning of the inquiry, before the changes made by Cecil in midNovember, Mary was ultimately positive about the prospects of the conference over the legitimacy of the Casket Letters. The letters Mary wrote during this early period show that she genuinely believed that the English commissioners might actually aid in repairing her relationship with the Confederate Lords who had forced her to abdicate her throne. Mary was determined to use her political connections with other rulers, especially Catholic rulers, in order to assist her case. One of the most notable things that Mary

\footnotetext{
${ }^{273}$ Mary Stuart, Queen of Scotland, "Letter Dated October 22, 1568: The Queen of Scots to M. de la Forest," in vol. 1 of Letters of Mary Queen of Scots, ed. A. Strickland (London: Henry Colburn, 1842), 90. Strickland, in another of her works, refers to this man as "la Forêt" in discussing French ambassadors to Elizabeth's court. She makes a note that la Forêt and another ambassador arrived at court in England in September of 1568. I have retained her spelling as found in the volume of letters as it is possible Strickland simply anglicized the name in her edition of the letters. Little is to be found about this man outside references by Strickland and he generally appears to be a minor diplomat. Agnes Strickland, Lives of the Queens of England, vol. 6 (London: Henry Colburn, 1843), 297.
} 
describes in this letter is that she believes her ambassadors were sent for by Elizabeth "for the purpose, I believe, of bringing our affairs to a more speedy settlement, agreeably to her wish." ${ }^{274}$ Guy remarks that Mary questioned the legality of the conference but had little choice in agreeing to it. This letter, by contrast, shows that she was positive about the prospects. ${ }^{275}$ The latter part of the note reveals Mary's reluctance as she still needed to request assistance in proving her innocence.

Mary wrote to Monsieur de la Forest in the hopes that he would assist her representatives at York to participate in the inquiry. Mary noted that she had requested her representatives, especially the Bishop of Ross, "to inform you what they have already negociated [sic] in the said conferences, as well as to confer with you upon the proposals which may be made them while there." ${ }^{276}$ Mary also requests that de la Forest "by the good-will and affection I know you to entertain for me, to tell them freely your opinion on the subject." ${ }^{277}$ Mary was requesting assistance in the case that was being debated at York. In this letter, Mary reveals that she is still uncertain about the negotiations taking place and decided to write to another ambassador, who was not involved, in order to ask for advice on behalf of her representatives. This language makes appearances in letters to other rulers, such as in the letter to Elizabeth which will be examined in this chapter. If Mary was anxious about whether the case that her half-brother and his allies were making would be taken seriously, it is not reflected in this letter, but what is clear is that she sought assistance where she believed she had allies. Turning to the French ambassador for unofficial advice was a wise political move in light of the investigation. The French

\footnotetext{
${ }^{274}$ Mary Stuart, "Letter Dated October 22, 1568: The Queen of Scots to M. de la Forest," 90. ${ }^{275}$ Guy, Queen of Scots, 416.

${ }^{276}$ Mary Stuart, "Letter Dated October 22, 1568: The Queen of Scots to M. de la Forest," 91. ${ }^{277}$ Mary Stuart, "Letter Dated October 22, 1568: The Queen of Scots to M. de la Forest," 91.
} 
had long been Mary's political allies and seeking advice from a trusted source in these unusual circumstances showed that Mary treated the inquiry into the Casket Letters seriously. The letter also shows that Mary was attempting to ensure that her defence was strong against the accusations of murder and adultery which had not yet been officially levelled at her, but which she, in all likelihood, knew were possible.

On the same day, October 22, Mary wrote to Elizabeth from her captivity at Bolton. This letter too reflects the initially positive outlook Mary had on the proceedings. The letter opens with the traditional address of Elizabeth as her "good sister," which has been established throughout this project as being typical of the address between rulers. ${ }^{278}$ In the previous chapter, in the discussion of the letter from July $5^{\text {th }}, 1568$, it was shown that this address was selectively used by Mary and was more than mere convention. ${ }^{279}$ When Mary was angry, outraged or indignant she would purposefully omit this greeting, meaning its presence showed the relatively positive tone of the letter, especially in light of Mary's anger of a few months previous. Mary also reported that she expected the conference on the letters "to be now of short duration." 280 This letter reflected the generally positive beginning of the inquiry into the Casket Letters, which had begun earlier in the month. Here the emotional tone of Mary's letter was not one of anger but of kinship and friendly feeling.

In this letter Mary focuses on the friendship and kinship often mentioned in other letters to Elizabeth. Once again usage goes beyond mere convention and reveals Mary's

\footnotetext{
${ }^{278}$ Mary Stuart, Queen of Scotland, "Letter Dated October 22, 1568: The Queen of Scots to Queen Elizabeth," in vol. 1 of Letters of Mary Queen of Scots, ed. A. Strickland (London: Henry Colburn, 1842), 91.

${ }^{279}$ Page 13 of Chapter 2

${ }^{280}$ Mary Stuart, "Letter Dated October 22, 1568: The Queen of Scots to Queen Elizabeth," 91.
} 
rhetorical goals in her letters to Elizabeth. In this letter specifically Mary again references that Elizabeth is her "good sister" and her "only friend," while signing the letter as her "affectionate good sister and cousin." ${ }^{281}$ Mary also emphasizes that she came to Elizabeth's kingdom to "throw myself into your arms," a performative gesture in seeking mercy from another. ${ }^{282}$ While the gesture was not gendered as uniquely feminine, the virtue of mercy was often seen as the trait of a good, Christian woman during the medieval and early modern period, we can consider the gesture in this context to be coded feminine. The focus on feminine kinship and friendship and even supplication is significant as it is completely different from Elizabeth's strategy of often attempting to eschew her femininity, at least in the political sphere. Elizabeth, as an unmarried ruler who was also a woman, was well known for her rhetorical adaptation of the Tudor understanding of the "two bodies of the king" for her personal situation. The concept largely developed during the reign of Edward VI and maintained that the king had a body natural that was like any other man, susceptible to death or illness, but that he also possessed a body politic that permitted them to rule over others. ${ }^{283}$ Elizabeth often described her body politic as being masculine even though her body natural was feminine. ${ }^{284}$ In a speech to Cecil and other lords before her coronation in November of 1558, Elizabeth proclaimed that despite being a woman, she had been granted a body politic by God, through which she would rule. ${ }^{285}$ The most famous example of this

\footnotetext{
${ }^{281}$ Mary Stuart, "Letter Dated October 22, 1568: The Queen of Scots to Queen Elizabeth," 92.

${ }^{282}$ Mary Stuart, "Letter Dated October 22, 1568: The Queen of Scots to Queen Elizabeth," 91.

${ }^{283}$ Cheryl Glenn, Rhetoric Retold: Regendering the tradition from antiquity through the Renaissance (Carbondale: Southern Illinois University Press, 1997), 163.

${ }^{284}$ Glenn, Rhetoric Retold, 163.

${ }^{285}$ Elizabeth Tudor, Queen of England, "Queen Elizabeth's First Speech, Hatfield, November 20, 1558," in Elizabeth I: Collected Works, ed. L. S. Marcus, J. Mueller and M. B. Rose (Chicago, University of Chicago Press: 2000), 52.
} 
strategy comes from Elizabeth's speech to her troops at Tilbury in 1588, a year after Mary's execution. In this speech, Elizabeth proclaimed, "I know I have the body but of a weak and feeble woman, but I have the heart and stomach of a king and of a king of England too."286 One of the most significant differences between the manner in which Mary and Elizabeth presented themselves, was that Mary did not adopt the same strategy as her contemporary. Much of Mary's writing, especially her poetry and letters, placed a strong focus on emotion and femininity, as examined in the previous chapter. Though Mary had previously referred to female rulers like Elizabeth as 'princes,' Mary often chose to emphasize the feminine in her letters to Elizabeth. Janel Mueller argues that Elizabeth preferred this term, 'prince,' for herself as a ruler because the word princeps in Latin lacks an association with either a feminine or masculine gender. ${ }^{287}$

In this letter, Mary was attempting to blend the ideas of feminine kinship and traditionally masculine political power. Mary reports that she was happy about Elizabeth's commitment to "take upon yourself the trouble of putting to end the too long differences between me and my subjects." ${ }^{288}$ She also stated her conviction that Elizabeth "as my good sister and only friend, convinced that you will be as favourable to me as you have always promised, if I followed your good advice, which I have done and intend to do, as you may learn more fully from the Bishop of Rosse and my Lord Heris."289 Emphasis on friendship was a common strategy of women's letters during the early

\footnotetext{
${ }^{286}$ Elizabeth Tudor, Queen of England, "Queen Elizabeth's Armada Speech to the Troops at Tilbury, August 9, 1588," in Elizabeth I: Collected Works, ed. L. S. Marcus, J. Mueller and M. B. Rose (Chicago, University of Chicago Press: 2000), 326.

${ }^{287}$ Janel Mueller, "Virtue and Virtuality: Gender in the Self-Representations of Queen Elizabeth I," in Virtual Gender: Fantasies of Subjectivity and Embodiment, eds. M. O'Farrell, L. Vollone (Ann Arbor: University of Michigan Press, 1999), 225.

${ }^{288}$ Mary Stuart, "Letter Dated October 22, 1568: The Queen of Scots to Queen Elizabeth," 91.

${ }^{289}$ Mary Stuart, "Letter Dated October 22, 1568: The Queen of Scots to Queen Elizabeth," 91.
} 
modern period, especially in women's letters of recommendation. ${ }^{290}$ Friendship as used in letters evoked a sense of reciprocity, something Mary clearly understood from evidence in this letter as well as the letter to de la Forest. In this letter Mary was attempting to show, with both her writing and testimony from her subjects, that she had held up her end of this political friendship and that it was now time for Elizabeth to do the same. This letter shows that Mary was attempting to blend the traditionally masculine political, here exemplified in the concern for her subjects and the repair of her relationship with them for the good of her kingdom, as well as the feminine kinship and friendship she shared with Elizabeth as her 'sister.' The letter also shows that Mary was still firm in her belief that she was the rightful ruler and that the reciprocal political relationship with Elizabeth remained key not only to repairing her relationship with her subjects but also in returning her to the throne.

Mary's attempts to convince Elizabeth to assist her did not result in the inquiry finding the Scottish queen innocent. By December the inquiry into the Casket Letters had started to go badly wrong for Mary, and she had clearly soured towards Elizabeth and the inquiry in the next letter we will examine. Mary wrote a letter to the Abbot of Arbroath, dated by Strickland to December 9. As Strickland provides no manuscript numbers for the letters in her edition it is unclear as to where this letter is currently housed. The letter is of substantial length, covering four pages in Strickland's volume. It is significant to note that the dating of this letter appears to come not from the text of the transcribed letter but rather from Strickland herself. In most of the other letters in the collection, the

\footnotetext{
${ }^{290}$ James Daybell, "Women's letters of recommendation and the rhetoric of friendship in sixteenth-century England," in Rhetoric, Women and Politics in Early Modern England, eds. J. Richards, A. Thorne (London: Routledge, 2006), 179.
} 
date is indicated in one of the last lines of the text. The place in which the letter was written is also usually given, which was also the case of the original transcriptions produced for this project. In the case of this letter, however, the date appears in square brackets as "9 December, 1568 " and no location is apparent. ${ }^{291}$ It is also important to note that Strickland presents December 9 as the day that Moray finally officially presented the Casket letters to the conference. ${ }^{292}$ John Guy disagrees with this dating and suggests the letters were presented to the conference on the 7, the day after Mary's advocates had been ordered by their queen to withdraw from the proceedings. ${ }^{293}$ Strickland makes note in her timeline of the events of this year that it was on the third of the month that the Bishop of Ross presented a complaint on behalf of Mary that unless she could defend herself in person then the conference should be terminated. ${ }^{294}$ Regardless of the precise dating of the letter and whether it was written before or after the letters were formally produced by Moray, it is clear from both the content of the letter and the context that when it was written Mary was very aware that the tides had turned against her in the inquiry and that her representatives had withdrawn.

In the letter Mary appeals not to friendship but instead to duty and loyalty in order to seek support from a recipient. Mary clearly attempts not only to stir up loyalty in her recipient but also to present herself as a suffering queen. The letter represents a slight deviation in Strickland's edition. The letter, noted as having been written December 9, 1568 , is one of very few letters in the edition of Mary's correspondence that appears to be a diplomatic transcription. Most of the other letters do not retain original spellings and

\footnotetext{
${ }^{291}$ Mary Stuart, "Letter Dated December 9, 1568," 103.

${ }^{292}$ Agnes Strickland, ed., Letters of Mary Queen of Scots, London: Henry Colburn, 1842), 103.

${ }^{293}$ Guy, Queen of Scots, 418.

${ }^{294}$ Agnes Strickland, ed., Letters of Mary Queen of Scots, London: Henry Colburn, 1842), 99.
} 
appear to be significantly modernized in both spelling and punctuation. This letter, however, largely adheres to norms of period spelling which can also be seen in my own transcriptions. Words like "mynisters" are not rendered in the modern spelling as they are in other letters, and Elizabeth is referred to as the "Q. of Ingland," a common spelling in the English of the period, indicating that the transcription was from a letter written in English. ${ }^{295}$ It may be that the other letters in this volume are translations of French or Latin, two of the languages in which Mary often chose to write letters, and that with the translation of those letters into English by Strickland, the spellings and punctuation were modernized. While this explanation seems likely it is very difficult to verify without the original letters, which is a task further complicated by the fact that Strickland neither provides the language in which the source text was written, nor indicates where the material might be found.

The letter was addressed to the Abbot of Arbroath, who presided over one of the major abbeys in Scotland. The abbey was powerful during the late medieval period and fell under the Bishop of Moray. In this letter Mary recounts not only the injustices against her but also those committed against the abbey by Elizabeth. At the time of this letter, George Douglas, the illegitimate son of the Earl of Angus, was the Abbot of Arbroath, recently elected for the second time. He would later become the Bishop of Moray. ${ }^{296}$ During this period the deposed queen still had a considerable amount of support in Scotland. The Marian civil war, which began in 1568, following Mary's escape from

\footnotetext{
${ }^{295}$ Mary Stuart, Queen of Scotland, "Letter Dated December 9, 1568: The Queen of Scots to the Abbot of Arbroath," in vol. 1 of Letters of Mary Queen of Scots, ed. A. Strickland (London: Henry Colburn, 1842), 99.

${ }^{296}$ Reverend Robert Keith, An Historical Catalogue of the Scottish Bishops Down to the Year 1688 (Edinburgh: Bell \& Bradfute, 1824), 151.
} 
Lochleven, pitted the queen's men, who supported Mary, against the king's men, who supported Moray and his regency in the name of James. There is little written about George Douglas beyond his position as Bishop of Moray, which he only took in 1573, and little to show why Mary might have been writing to him. ${ }^{297}$ His predecessor as Abbot of Arbroath was James Beaton who became the Archbishop of Glasgow and who was a strong supporter of Mary's. ${ }^{298}$ The latter portion of the letter in which Mary offers assistance to the abbot is much shorter, and much more space is devoted to the inquiry. It is possible that Mary was attempting to secure the continued support of the abbey, as she had enjoyed with Beaton. In this letter Mary presents the trial as unfair and suggests that Elizabeth has reneged on her promises to her fellow queen. This betrayal is one Mary takes very seriously and in writing to one of her supporters she hopes to further garner his loyalty in the face of his queen's persecution.

Mary begins the letter discussing the ways in which Elizabeth has broken numerous promises in favour of the Confederate Lords generally and Moray in particular. These remarks are statements of fact and Mary is attempting to show evidence for the fact that she has been mistreated during the course of the proceedings of the inquiry. She first establishes the facts of the events, and subsequently draws more emotionally charged conclusions in order to inspire loyalty from her subject. Mary complains that though Elizabeth promised to be a mediator for the two sides, "my matters has been prolongit in delaies, and in the mean tyme that my rebelles practizit secretly with her and her mynisters. ${ }^{299}$ According to Guy, this accusation is well founded, at least on the charge

\footnotetext{
${ }^{297}$ Keith, An Historical Catalogue of the Scottish Bishops, 151.

${ }^{298}$ Mark Dilworth, "Beaton, James," Oxford Dictionary of National Biography, 23 September, 2004.

${ }^{299}$ Mary Stuart, “Letter Dated December 9, 1568,” 100.
} 
that the Confederate Lords were meeting secretly with members of Elizabeth's court. The private viewings of the letters before they were presented in court was one of the ways in which Moray and the other lords attempted to keep the inquiry in their favour. All Mary's representatives had to do was claim the letters planning Darnley's assassination did not belong to Mary and then adversely accuse the Confederate Lords of complicity in the murder. The proceedings would then turn against the lords. ${ }^{300}$ Mary also states that Elizabeth has supported Moray and "maintaine him in the usurpinge of my authority and cause him to be declarit to suceede to the cronne of Scotland after the death of my sonne, in case he die without succession of his bodie." ${ }^{301}$ In Mary’s mind, confirming Moray in the succession of the Scottish throne was equivalent to Elizabeth supporting his rebellion against Mary, regardless of the fact that at the time this letter was written the outcome of the inquiry had not been decided. This review of generally factual evidence suggests Mary's true reason for writing, to maintain the loyalty of a subject to her cause.

Following the presentation of evidence that she has been mistreated Mary appealed to the emotions of her Scottish recipient by representing herself as a suffering queen. She made a careful effort to present the inquiry as counter to the well-being of the realm of Scotland. Not only had the Confederate Lords rebelled against her, but Elizabeth's support of them would contribute to the downfall of her kingdom. Attempting to show that Elizabeth was a danger to Scotland was very different to the way Mary wrote about her in her letter directly to Elizabeth. In her letter to Elizabeth, she conjured the image of the two queens as women who both needed to defend their divine appointments as rulers. Mary wrote, following her outline of the broken promises of

\footnotetext{
${ }^{300}$ Guy, Queen of Scots, 417.

${ }^{301}$ Mary Stuart, "Letter Dated December 9, 1568," 100-101.
} 
Elizabeth, "the sayde Queue of Ingland myndes haill [sic] for the run and destruction of my haill realme." 302 Not only are the broken promises a personal betrayal, but Elizabeth can no longer be trusted as an ally to the Scots as her behaviour threatens their country. The image of Elizabeth as friend in the previous letter and foe in the letter to the Abbot shows Mary's rhetorical flexibility based on her audience. The implication here is that only Mary's restoration had the ability to protect her country from the forces that sought to destroy it, both internal in the form of the Confederate Lords and external in the form of English interests. Mary also remarks of Elizabeth that her "promisis was otherwise as I looked for. But God and guid Scotts hartes of my subjects remedie the same." ${ }^{303}$ Not only did Mary refer to the Scots as her subjects, reiterating that she is still the rightful ruler, but she also noted that God and the people were on her side, not on the side of the English and the lords who pandered to them. She wrote that the most important action to be taken was to declare Moray a rebel, proclaiming, "amongst the chiefe of my revelles with the auntient and natural enemies of my realme: and this restid nothing now but to establishe and assure the said Karle [sic] of Murray in his usurpinge against my autoritie." 304 Here the connection between Moray and Elizabeth is further established as dangerous. Mary recalled the long history of strife between the kingdoms of Scotland and England and the collaboration between Elizabeth and a rebel as an extension of that history. Mary not only displayed an image of herself as a persecuted queen, but she also attempted to establish not only that her realm is threatened but also that God and loyal subjects are being threatened by the collaboration with the English.

\footnotetext{
${ }^{302}$ Mary Stuart, "Letter Dated December 9, 1568," 101.

${ }^{303}$ Mary Stuart, "Letter Dated December 9, 1568," 101.

${ }^{304}$ Mary Stuart, "Letter Dated December 9, 1568," 101-102.
} 
Mary's letters were not the only instance in which she portrayed herself as a suffering queen. Joy Currie, in her assessment of the poetry Mary produced in captivity in England, states that this image of herself was one Mary often used. She presents herself as a sorrowful and suffering, but still pious, queen. ${ }^{305}$ Here again, Mary was not afraid of the feminine connotations of the image she presented. The persecuted queen is an image that was more useful to her in obtaining sympathy from her allies abroad, or indeed from Elizabeth. Currie states that Mary's poetry throughout her life, beginning with the poem written after the death of her first husband Francis, focussed on gaining sympathy through the expression of genuine emotion. ${ }^{306}$ Mary uses descriptions of impending doom for Scotland to stir up the loyalty of her recipient and to attempt to prejudice him against Moray and the English. She herself is characterized as the suffering queen who fears for the destruction of her country and thus a compassionate queen. This self-presentation by Mary is key to maintaining her Scottish supporters by showing herself to be the true monarch and as the only one who had the interests of the realm at heart. This strategy will become more common for Mary, especially as the inquiry continued to be prejudiced against her, and even in her later imprisonment in England.

The next source differs from the others examined in this thesis as it is not a letter but rather the statement issued by Mary through her delegates at the conference on the Casket Letters. The document shows a logical and organized side of Mary's writing which has not previously been seen in this thesis. Mary worked to blend the logical

\footnotetext{
${ }^{305}$ Joy Currie, "Mary Queen of Scots as Suffering Woman: Representations by Mary Stuart and William Wordsworth," in "High and Mighty Queens" of early Modern England: Realities and Representations, eds. C. Levin, J. Eldridge Carney, D. Barrett-Graves (New York: Palgrave Macmillan, 2003), 190.

306 "Mary Queen of Scots as Suffering Woman," 192.
} 
presentation of arguments with her own personal tendencies towards earnest emotional expression in order to defend her decision not to formally abdicate her throne. This document exists in somewhat of a liminal space in terms of genre and format. The statement was delivered as more of an oration in the voice of the queen and from her perspective, but through a third party, not by Mary herself, which she likely knew at the time she wrote it. The document is not therefore a legal defense as would be submitted in a trial, as the inquiry occurred in complicated legal circumstances. It was not technically a criminal court, though criminal charges were presented by Moray and the other Confederate Lords. Labanoff's collection of Mary's correspondence includes this document and also includes a transcription of an endorsement by Cecil reading, "1568, 9 Janua: die Dominii. -- French wrytyng delyvered by y Scott. Q. Ambassad." $^{\text {e } 07}$ The date of the endorsement by Cecil seems to place this document on the day before Cecil released the statement effectively issuing a stalemate between the parties. ${ }^{308}$ It also places a statement supposedly given by Mary's commissioners after the time the conference was dissolved by Elizabeth. It is possible that Cecil endorsed the document after the proceedings had closed and wrote the date he endorsed the document rather than the date the document was delivered. Despite the nature of the document and its obvious difference from the other pieces of correspondence contained within this project, it is nonetheless a significant example of how Mary used rhetoric during her time as a deposed queen.

\footnotetext{
${ }^{307}$ Mary Stuart, Queen of Scotland, "Statement by Queen Mary, Presented by her Commissioners at the Conferences," in Letters of Mary Stuart, Queen of Scotland, ed. Prince Alexander Labanoff, trans. William Turnbull, Esq. (London: Charles Dolman, 1845), 169. From the modern perspective, the year would actually be 1569, but in England, the calendar year did not change until March 25, the day of the Feast of the Annunciation, or Lady Day.

${ }^{308}$ Warnicke, Mary Queen of Scots, 184-185.
} 
This statement was not the first that Mary had written to be presented in public. When Mary was twelve years old she read a Latin declamation in the great hall of the Louvre Palace in Paris. The event was observed with a keen eye as an evaluation of Mary's education and the content of the presentation actually defended the education of women in response to a French courtier who said girls should not be educated and some reports were highly complimentary. ${ }^{309}$ This oration, from much later in Mary's life, showed the influence of Mary's humanist education and her attempt at using traditional elements of oration in her writing to appeal to her audience of educated courtiers. Of course in this case, Mary was aware of her hostile audience and that it was necessary to convince them to her side. The content of the document primarily concerns her unwillingness to reaffirm her abdication from the Scottish throne and completely renounce her claim. Mary states she will not do so, gives a list of reasons why she believes this action is correct, and closes by reaffirming her initial statement. In this document Mary attempts to both present a cogent legal argument as well as sway her audience with her conviction to her cause: a combination of the Aristotelian pathos and logos.

Mary opens the statement by discussing her abdication, and it is clear from the beginning of the document that she still believes that the abdication during her imprisonment at Lochleven was illegitimate. As discussed in the previous chapter, scholars widely agree that Mary was threatened into signing her declaration of abdication on July $24^{\text {th }}, 1567$, which Parliament ratified in December of the same year. ${ }^{310}$ She states

\footnotetext{
${ }^{309}$ Guy, Queen of Scots, 71.

310 James Anderson, "Four Acts of the Parliament of Scotland, Holden in December 1567," in Collections Relating to the History of Mary Queen of Scotland (Edinburgh: Mosman and Brown, 1727), 208.
} 
that she wishes for there to be no further calls for her to renounce her throne, stating, "for I am resolved and determined to die sooner than do so; and the last word I shall utter in this life shall be that of a Scottish Queen." ${ }^{311}$ Following the establishment of her resolve not to abdicate she states that her decision has been influenced not only by emotion or conviction but, "for the following and other and more cogent reasons moving me thereto." ${ }^{312}$ Mary knew that simply stating her faith in her God-given right to govern would not be sufficient to sway her audience. Instead of focussing on her rank, it was more prudent to present a rational argument in this case. Her focus on "cogent reasons" emphasizes the influence of the format on how Mary wrote her statement. Mary's questions about the legality of putting a foreign sovereign under investigation had proven that simply stating she was a queen would be insufficient to convince the ministers; she had to play into the forum that Elizabeth and Cecil had set up. In addition, all of the men who had been appointed to judge her case were well-educated in the humanist tradition as she was, meaning that she needed to present a competent argument in order for them to consider her side.

The first argument in this statement is that abdication would be contrary to all that Mary had been arguing for previously and would result in a degradation of her character. Mary argued that if she were to abdicate in spite of the fact that her subjects had rebelled against her authority and asked, "what would the public say, but that I have been my own judge and condemned myself?"313 Mary was stating that to abdicate in the face of the accusations that have come against her would be tantamount to admitting her guilt.

\footnotetext{
${ }^{311}$ Mary Stuart, "Statement by Queen Mary," 167.

${ }^{312}$ Mary Stuart, "Statement by Queen Mary," 167.

${ }^{313}$ Mary Stuart, "Statement by Queen Mary," 167.
} 
Additionally, Mary stated that if she were to abdicate the public would, "say that it is from fear of being publicly arraigned, and from a conviction of my own guilt and of having a bad case, that I prefer to pay, rather than to plead, and thereby save myself from condemnation." 314 If Mary conceded to requests for abdication, it would present her as guilty, regardless of what the inquiry revealed. Reaffirming her abdication when she had already claimed her abdication at Lochleven was illegitimate, and thus going back on her claim, would only result in Mary being the subject of "special abhorrence by all the people of this island" for abdicating in an attempt to placate those she had accused of rebelling against her. ${ }^{315}$ In light of this argument, Mary could not abdicate because she would be going back on the accusations she made against the Confederate Lords and admitting guilt, something she had no intention of doing.

Mary's next argument was that she, having abdicated her throne, would be a private citizen which would cause additional problems if she were to remain in England. Mary stated that if she were a private citizen, she would be liable to being charged in English courts for the crimes she is accused of and face more danger than she was hoping to escape in Scotland. Mary remarked that "through the suggestions of my enemies or otherwise, the Queen of England wished me to submit to whatever laws or the jurisdiction of such judges as seemed good to her, she would have a pretext for doing so." ${ }^{316}$ Mary suggested that losing her legal status as a monarch would make her liable for her enemies to target her in criminal courts in England, making her more vulnerable to those who wished to hurt her. In addition to this Mary stated that if Elizabeth were to die

\footnotetext{
${ }^{314}$ Mary Stuart, "Statement by Queen Mary," 167.

${ }^{315}$ Mary Stuart, "Statement by Queen Mary," 167.

${ }^{316}$ Mary Stuart, "Statement by Queen Mary,” 167-168.
} 
without a declared heir, "those who contended for the crown would be enabled, seeing the small account in which I should be held, to seize my person, and under the pretence aforesaid, do that which perhaps my said good sister would not have thought of."317 Mary's legal status was assisting in protecting her from her enemies in the event that Mary would be left as the most obvious successor. Noticeably, Mary's argument was not that she should be exempt from the current pseudo-trial because she was a monarch but rather that unjust persecution was possible if she lost her status as a monarch. In this argument again, Mary established that abdication would leave her vulnerable, not just to the ire of her people, but also to her enemies. She had to maintain the legal status that might protect her. She of course did not know that she would eventually be tried and executed with her legal status as a monarch intact.

The final arguments Mary presented were that if she were to abdicate her son, James VI, would have difficulty in gaining obedience from his subjects as the principles of the monarchy would have been threatened by acquiescing to the demands of rebels. In addition, she states that if James were to die without an heir, the consequences would be disastrous not only for herself, but for Scotland as a whole as well. If Mary had abdicated and her son were to die then she argued, "my crown would fall into other hands, and neither myself, nor others born of me, could regain it." ${ }^{318}$ Her abdication would threaten her dynasty and would prevent the crown from going to her family line if her son died without issue. Mary outlined that she would personally be in danger if she were a private citizen if her son died without a successor, stating "I should be in perpetual fear of my life, for whosoever should be seated on my throne would never rest until he was assured

\footnotetext{
${ }^{317}$ Mary Stuart, "Statement by Queen Mary,” 168.

${ }^{318}$ Mary Stuart, "Statement by Queen Mary," 168.
} 
by my death. ${ }^{״ 19}$ In addition to the personal danger Mary assessed that Scotland's diplomatic future would be destabilized as, "I make no doubt that the ancient alliance of France would not be ratified with him who should reign." ${ }^{320}$ Mary and her family had long championed the auld alliance between Scotland and France and there had been conflicts over whether England should be considered as a more attractive ally throughout both her regents' rule and her personal reign. Mary presented the dissolution of the French alliance as a necessarily negative development. In addition to the conflict that would arise if James would die without an heir, Mary claimed abdication would hurt her son's reign. Mary claimed that with her abdication there will be some Scottish subjects who will remain loyal to her and attempt to fight for her interests. She stated that with her abdication, "we must not expect that there will be peace in my kingdom, but on the contrary two factions, who perchance may be fostered by some in this country for particular objects; and although things may be done on both sides in the name of my son, it will always happen that they come to different ends; and that he will never have entire obedience." ${ }^{, 21}$ Mary claimed that her abdication would deepen the existing factionalism in her country, perhaps aided by outside influence from the English to their own aims, and that this conflict may cause the "complete ruin of my kingdom.." ${ }^{322}$ In these statements Mary makes a connection between her own well-being and the well-being of the State of Scotland. Her body politic is inextricably tied to the state. In this argument Mary presented her abdication as an unnatural attempt to separate her body politic from her body natural, thus throwing herself, her son and her country into further conflict. She

\footnotetext{
${ }^{319}$ Mary Stuart, "Statement by Queen Mary," 168.

${ }^{320}$ Mary Stuart, "Statement by Queen Mary," 168.

${ }^{321}$ Mary Stuart, "Statement by Queen Mary," 168-169.

${ }^{322}$ Mary Stuart, "Statement by Queen Mary," 169.
} 
was not only drawing on the ethos of her status as a monarch as well as the pathos of her emotional declarations of her commitment to her crown. In the opening of the statement to the conference Mary stated she was unwilling to abdicate, "for I am resolved and determined to die sooner than do so; and the last word I shall utter in this life shall be that of a Scottish Queen." ${ }^{\prime 32}$ The only thing which has the capability to sever her body politic is death because as long as she lives, she possesses the two bodies of a monarch. Her final argument was one of a queen anointed to rule who has the best interests of her kingdom at heart. These logical arguments justify Mary's refusal to entirely forsake her crown in more complex terms than simply the fact that it was hers by right. Mary presented these arguments in an effort to adhere to the conventions of the inquiry and defend herself against these repeated calls for her abdication.

Despite her commitment to presenting logical arguments in this particular statement, that did not restrict Mary from reminding her audience that she was not only an anointed queen but also show them her commitment to her course of action. Mary also mirrored these convictions in her closing statement: "I am determined that I shall not lightly throw away what God has given to me, and that I am resolved rather to die a queen. ${ }^{\prime 324}$ In light of her carefully structured arguments that came between these statements, they appear rather emotional or dramatic. Joy Currie has examined Mary's self-presentation in her poetry and her commitment to her rule is a common thread that weaves throughout Mary's writing. In "A Sonnet from Forthingay Castle," from later in her imprisonment, Mary laments her inability to regain her throne and ponders the purpose of her life in prison. Currie uses this as an example of Mary's mourning her loss

\footnotetext{
${ }^{323}$ Mary Stuart, "Statement by Queen Mary," 167.

${ }^{324}$ Mary Stuart, "Statement by Queen Mary," 169.
} 
of self, which, for her, is inextricably tied to her rule. ${ }^{325}$ Mary was, in a sense, fighting to maintain her identity along with presenting the logical and carefully constructed arguments that her examiners expected. Mary still found a way to inject her own personal voice and her characteristic passion into this defense of her decision.

Mary faced considerable challenges in the face of the inquiry into the Casket Letters. Without having the power to change her situation as a fleeing monarch, she turned to rhetoric to assist her in winning support. These writings, though separated from those of the last chapter by only a few months, show a much more varied rhetorical approach on Mary's part. She continued her previous commitment to write in an earnest voice and to continue her characteristic sincere expression of emotion to persuade her audience, whether that emotion was positive or negative. In these writings however, she showed more range, especially in constructing the image of herself as a suffering queen who was being unfairly persecuted in the light of her current situation, an image which she would further establish later in her imprisonment. Mary also showed herself to be aware of the gendered rhetoric used by Elizabeth in the early part of her reign and chose to adopt it in combination with her own references to feminine friendship and kinship. These strategies show Mary as a flexible and savvy rhetorician who was able to tailor her strategies to her audience and circumstance in order to produce the desired effect.

${ }^{325}$ Currie, "Mary Queen of Scots as Suffering Woman," 194. 


\section{Conclusion}

While Mary's letters have previously gone unexamined by scholars, as this thesis has shown, they provide a rich area of study. Her letters reveal her to be a flexible rhetorician, able to use her humanist education in order to convince and communicate, on a level comparable with her cousin Elizabeth I, though there are distinct differences in the manner in which the two women presented themselves. Examining Mary's letters offers a more nuanced study both of her reign and of early modern queenship generally, especially as it relates to gender and self-presentation. Mary's rhetorical flexibility has been largely unrecognized and shows her to be a ruler who was aware of her circumstances and who acknowledged the need for differing strategies based on her audience and the subject matter. During her personal reign, her letters were an important way in which she exerted her influence and power over her subjects and her diplomatic network. As Mary's political power waned following her abdication, her letters became one of her only outlets to express herself and continue to act in the political sphere.

During her personal reign Mary used her letters as a way to establish and maintain diplomatic connections with her international network. Letters that were written concerning specific events relied on assertions of authority in order to protect her sovereignty when it was being threatened. Letters that had more general goals like the maintenance of diplomatic ties to another ruler focused on self-presentation and focus on ties of kinship and religion. These differing strategies based on circumstances were also varied based on whether Mary was writing to another ruler or to an ambassador or other diplomatic agent. Letters to diplomatic agents were focussed on the day-to-day operation of the diplomatic network as they issued requests, discussed travel and provided 
instructions. Letters to fellow monarchs were more focused on providing reasoning for a continuing diplomatic relationship, including references to shared rank, kinship or religion.

Following her imprisonment in England, the primary goal of Mary's letters was to obtain support for her reinstatement as the queen of Scotland after her abdication. Her letters focussed on ideas of rank, kinship and justice as she sought support from a number of different sources. During this period one of the key ways in which Mary sought aid from her correspondents was her use of emotional language in her letters. Use of emotional language in order to maintain her diplomatic connections was essential as, at the time, Mary was isolated from many of her supporters. Her use of emotional language and her rhetorical appeals to rank, kinship and justice supported her argument that her return to Scotland and to her throne was the right course of action as she had been unlawfully deposed by her lords.

During the Casket Inquiry, Mary’s primary focus was attempting to ensure that the conference gave a result that was in her favour. The documents examined in the third chapter show Mary's flexibility in rhetorical strategy based on the progress of the inquiry and her audience, proving her to be a capable rhetorician in the face of the inquiry that might result in serious charges of murder and adultery. She used multiple methods of persuasion, again appealing to kinship and friendship as she did in her letters from chapter two. Mary was also able to create a statement to the conference that had clearly supported and reasoned arguments in order to appeal to the judges who were presiding over the inquiry, while still following her personal tendency to use emotionally charged language in her writing. In addition, she used specific methods of self-presentation in 
order to create an image of herself as a rightful queen, suffering from undue prosecution at the hands of her rebels. In all of these documents, she consistently presented herself as the true queen of Scotland, despite her abdication and her imprisonment in England.

The writings of Mary Stuart can be used as an important source for early modern queenship as well as contemporary ideas about rhetoric and gender. Mary's letters provide important insight into how her image as queen was deliberately constructed through the language she used. Using her letters as a source for this discussion places the focus on the image she wished to create, rather than those created for her by both her enemies and her allies. The concept of self-representation is one that has been explored significantly by scholars in reference to Elizabeth and that attention should rightfully be turned onto Mary. Her rhetoric not only shows the manner in which she presented an image of herself to her recipients but also the ways in which she sought to maintain or reassert her power as an anointed monarch. Discussions about how women blended ideas about gender and power into their writings can be further enriched by discussing Mary's letters. Her letters are an underutilized source for the history of women and gender in the early modern period.

This thesis has shown that Mary's rhetorical flexibility should be further studied. Her unique position as a queen who had lived in multiple countries throughout her life and her of knowing that she would be queen regnant from a very young age provides a rare opportunity for scholars to study queenship, gender and even transnationalism in the early modern period through the writings of a single individual. Nearly from birth, Mary was raised to be queen. Throughout her life, even following her forced deposition by the Confederate Lords who rebelled against her, she never wavered on the fact that she knew 
without doubt that she was the true queen of Scotland. Her determined faith in this matter influenced her writing throughout her life.

"I am determined that I shall not lightly throw away what God has given to me, and that I am resolved rather to die a queen." 326

${ }^{326}$ Mary Stuart, Queen of Scotland, "Statement by Queen Mary, Presented by her Commissioners at the Conferences," in Letters of Mary Stuart, Queen of Scotland, ed. Prince Alexander Labanoff, trans. William Turnbull, Esq. (London: Charles Dolman, 1845), 169. 


\section{Appendix A: Original Transcriptions}

Both transcriptions follow semi-diplomatic conventions in order to provide a clear picture of the text of the manuscripts. Spelling has not been modernized and capitalization has not been standardized. The letters $\mathrm{i} / \mathrm{j}$ and $\mathrm{u} / \mathrm{v}$ have also not been regularized. Contractions such as "our" are expanded, with supplied letters appearing in italics. Thorns have been replaced with 'th'. Punctuation has not been supplied and any punctuation, including virgules (/), that appear is provided in the manuscript. Text which appears in angle brackets $(<>)$ is text that has been deleted or crossed out in the original manuscript. Lineation and pagination of the manuscript has been preserved.

"Copy of the Q. of Scots' letter to the Q. of England; complaining of hostilities committed in Scotland by the English"

British Library (London), Burghley Papers, Lansdowne MS 8, f. 97.

Right excellent prince whereas latlie we are somerlie informed certain your Subjectes to the nommber of viii persones entered within our ralme of scotland at the townes of Edington and chaim since five miles from Berwicke or thereabout and there Not onlie made slaughter took prisoners spoiled and rest a great Quantitie of goodes but also Used them in such surtie as It had been upon Warre and hostilytie betwixt the twoe contryes and yet deteynes and kepes some of the persones At Berwick, as if It were instant warre A thing which we understand to be express against your mynd and pleasure in respect of your declaration divers wayes notyffyed unto us that your mayning hath been and alwaus is to enterteyne Peace and Quyetness < against> amongst the Subjectes of bothe contryes And albeit your counsile in our abseine to no sundry tymes wrote To the earle of Bedford your livetenante for redress of the same attemptes he not onlie inforsed to make the same but also by his servant sent with his answere sayde that he would plainlie take the ded upon hym 
selffe inviting the same to be doen at his Commandment as your agent Master Randolph being present at the declaration thereof can testyfye whereupon and being moved with the lamentable complante of our Subjectes we have taken occasion to wrytt privatly to you

Verso 97

derest Sister that you will ponder this matter according to the wright thereof and conseyence that thereon many followe And not only to take hastye order that the said attempt at may be spedilie redressed and also to make plaine demonstration that ye mislyke this and many other strange procedinges in hym who being your mynster ought to be most connsel to norushe grytness and enterteyne the good neyghborhead that heretofore have contyinued betwixt us And thus not doubting by your answere by this bearer to be cortysyed of your good mynde in that behalffe tendying to the dewe reformation of this so notoryous an affaire ryght excellent prince we comytt you to the protection of almyhtie god Given under our Signett at our palace of Holyrood house the last dae of december of our Reyne the xxiii $^{\text {th }}$ yeare 1565

"Copy of the Q. of Scots' letter to Mr. Randolph"

British Library (London), Burghley Papers, Lansdowne MS Vol 8, f. 121.

Trustie and welbeloved we grete you well wherever the Earle of Sutherland a borne Subject of this our ralme comying so beyonde sea and reparinge towardes this his native contrie was taken staid and detayned prysoner at Berwick we mirvalle of It in deed Seinge It a thinge tendinge so many so stlie to the brech of the good Intelligence betwixt us and our good sister the Queen that waynes, praing you therefore that you will write to the Earle of Bedforde with the bearer hereof / thus by your letter the same Earle of Sutherland may be put at libertie and 
Suffred to departe towards this ralme without stope or Inuestigacion as you will doe us good pleasure Subscrybed with our hande at Glasgow the viii of September 


\section{Bibliography}

\section{Primary Sources}

\section{Archival Material}

\section{British Library (BL), London}

Burghley Papers, Lansdowne MS Vol 8, f. 114.

Burghley Papers, Lansdowne MS 8, f. 121.

Burghley Papers, Lansdowne MS 8, f. 97.

\section{Printed Primary Sources}

Anderson, James. "Four Acts of the Parliament of Scotland, Holden in December 1567, with a List of the Members present in that Parliament." In Collections Relating to the History of Mary Queen of Scotland, 208-224. Edinburgh: Mosman and Brown, 1727.

Elizabeth Tudor, Queen of England, “Queen Elizabeth's Armada Speech to the Troops at Tilbury, August 9 ,1588.” In Elizabeth I: Collected Works, edited by Leah S. Marcus, Janel Mueller and Mary Beth Rose, 325-326. Chicago, University of Chicago Press: 2000.

Elizabeth Tudor, Queen of England, 'Queen Elizabeth's First Speech, Hatfield, November 20,1558." In Elizabeth I: Collected Works, edited by Leah S. Marcus, Janel Mueller and Mary Beth Rose, 51-52. Chicago, University of Chicago Press: 2000 .

Elizabeth Tudor, Queen of England. "Queen Elizabeth to Mary, Queen of Scots, February 24, 1567.” In Elizabeth I: Collected Works, edited by Leah S. Marcus, Janel Mueller and Mary Beth Rose, 116-117. Chicago, University of Chicago Press: 2000 .

Elizabeth Tudor, Queen of England, "Queen Elizabeth to Mary, Queen of Scots, June 23, 1567."'In Elizabeth I: Collected Works, edited by Leah S. Marcus, Janel Mueller and Mary Beth Rose, 117-119. Chicago, University of Chicago Press: 2000.

Mary Stuart, Queen of Scotland, "Letter Dated December 9, 1568: The Queen of Scots to the Abbot of Arbroath," In Letters of Mary Queen of Scots, Vol. 1, edited by Agnes Strickland, 99-103. London: Henry Colburn, 1842. 
Mary Stuart, Queen of Scotland, "Letter dated July 5, 1568: The Queen of Scots to Queen Elizabeth." In Letters of Mary Queen of Scots, Vol. 1, edited by Agnes Strickland, 58-63. London: Henry Colburn, 1842.

Mary Stuart, Queen of Scotland, "Letter dated, June 13, 1568: The Queen of Scots to Queen Elizabeth.” In Letters of Mary Queen of Scots, Vol. 1, edited by Agnes Strickland, 50-54. London: Henry Colburn, 1842.

Mary Stuart, Queen of Scotland, "Letter dated June 26, 1568: The Queen of Scots to Queen Elizabeth," In Letters of Mary Queen of Scots, Vol. 1, edited by Agnes Strickland, 55-58. London: Henry Colburn, 1842.

Mary Stuart, Queen of Scotland. "Letter Dated May 17, 1568: The Queen of Scots to Queen Elizabeth, From Workington.” In Letters of Mary Queen of Scots, Vol. 1, edited by Agnes Strickland, 40-44. London: Henry Colburn, 1842.

Mary Stuart, Queen of Scotland, "Letter dated, May 27, 1568: The Queen of Scots to Queen Elizabeth, From Carlisle.” In Letters of Mary Queen of Scots, Vol. 1, edited by Agnes Strickland, 45-49. London: Henry Colburn, 1842.

Mary Stuart, Queen of Scotland, "Letter dated, May 28, 1568: The Queen of Scots to Sir W. Cecil, afterwards Lord Burleigh." In Letters of Mary Queen of Scots, Vol. 1, edited by Agnes Strickland, 49-50. London: Henry Colburn, 1842.

Mary Stuart, Queen of Scotland. "Letter Dated October 1, 1565: The Queen of Scots to the Archbishop of Glasgow." In Letters of Mary Queen of Scots, Vol. 1, edited by Agnes Strickland, 17-20. London: Henry Colburn, 1842.

Mary Stuart, Queen of Scotland, "Letter Dated October 22, 1568: The Queen of Scots to M. de la Forest." In Letters of Mary Queen of Scots, Vol. 1, edited by Agnes Strickland, 90-91. London: Henry Colburn, 1842.

Mary Stuart, Queen of Scotland, "Letter Dated October 22, 1568: The Queen of Scots to Queen Elizabeth." In Letters of Mary Queen of Scots, Vol. 1, edited by Agnes Strickland, 91-92. London: Henry Colburn, 1842.

Mary Stuart, Queen of Scotland. "Letter Dated September 10, 1565: The Queen of Scots to Philip II" Letters of Mary Queen of Scots, Vol. 1, edited by Agnes Strickland, 16-17. London: Henry Colburn, 1842.

Mary Stuart, Queen of Scotland, "Statement by Queen Mary, Presented by her Commissioners at the Conferences." In Letters of Mary Stuart, Queen of Scotland, edited by Prince Alexander Labanoff, translated by William Turnbull, Esq., 167-169. London: Charles Dolman, 1845. 
Mary Stuart, Queen of Scotland. "To the Cardinal of Lorraine, 21 June, 1568." In Letters of Mary Stuart, Queen of Scotland, edited by Prince Alexander Labanoff, translated by William Turnbull, Esq., 162-164. London: Charles Dolman, 1845.

Mulcaster, Richard. "The Passage of Our Most Dread Sovereign Lady, Queen Elizabeth.” In Elizabeth the First and Her Age: Authoritative Texts Commentary and Criticism, edited by Donald Stump and Susan Fletch, 91-108. New York: Norton \& Company, 2009.

\section{$\underline{\text { Secondary Sources }}$}

Adams, Robyn. "A Most Secret Service: William Herle and the Circulation of Intelligence." In Diplomacy and Early Modern Culture, edited by Robyn Adams and Rosanna Cox, 63-81. London: Palgrave Macmillan, 2010.

Allinson, Rayne. A Monarchy of Letters: Royal Correspondence and English Diplomacy in the Reign of Elizabeth I. New York: Palgrave Macmillan, 2012.

Alford, Stephen. Burghley: William Cecil at the Court of Elizabeth I. New Haven: Yale University Press, 2008.

Beem, Charles. Queenship in Early Modern Europe. London: Red Globe Press, 2020.

Beemer, Cristy. "God Save the Queen: Kairos and the Mercy Letters of Elizabeth I and Mary, Queen of Scots." Rhetoric Review 35, no. 2 (2016): 75-90.

Bell, Ilona. Elizabeth I: The Voice of a Monarch. New York: Palgrave Macmillan, 2010.

Bell, Robin. Bittersweet Within My Heart: The Love Poems of Mary, Queen of Scots. San Francisco: Chronicle Books, 1992.

British Museum. A Catalogue of the Lansdowne Manuscripts in the British Museum: With Indexes of Persons, Places and Matters. London: British Museum, 1819.

British Library. 'Elizabeth: September 1565.' In Calendar of State Papers, Scotland: Volume 2, 1563-69, edited by Joseph Bain, 199-216. London: British Library, 1900, accessed through British History Online.

Broomhall, Susan. "Introduction." In Gender and Emotions in Medieval and Early Modern Europe: Destroying Order, Structuring Disorder, edited by Susan Broomhall, 1-16. New York: Routledge, 2016.

“Ordering Distant Affections: Fostering Love and Loyalty in the Correspondence of Catherine de Medici to the Spanish Court, 1568-1572." In Gender and Emotions in Medieval and Early Modern Europe: Destroying Order, 
Structuring Disorder, edited by Susan Broomhall, 67-88. New York: Routledge, 2016.

Currie, Joy. "Mary Queen of Scots as Suffering Woman: Representations by Mary Stuart and William Wordsworth." In "High and Mighty Queens" of early Modern England: Realities and Representations, edited by Carole Levin, Jo Eldridge Carney and Debra Barrett-Graves, 187-202. New York: Palgrave Macmillan, 2003.

Davis, Norman. "Introduction." In Paston Letters and Papers of the Fifteenth Century, Vol. 1, edited by Norman Davis, xxi-lxxxvii. London, Oxford University Press, 1971.

Daybell, James. “Gender, Politics and Diplomacy: Women, News and Intelligence Networks in Elizabethan England." In Diplomacy and Early Modern Culture, edited by Robyn Adams and Rosanna Cox, 101-119. London: Palgrave Macmillan, 2010.

The Material Letter in Early Modern England: Manuscript Letters and the Culture and Practices of Letter-Writing, 1512-1635. New York: Palgrave MacMillan, 2012.

Women letter-writers in Tudor England. Oxford: Oxford University Press, 2006.

"Women's letters of recommendation and the rhetoric of friendship in sixteenthcentury England." In Rhetoric, Women and Politics in Early Modern England, edited by Jennifer Richards and Alison Thorne, 172-190. London: Routledge, 2006.

Daybell, James and Andrew Gordon. "Living letters: Re-reading correspondence and women's letters." In Women and Epistolary Agency in Early Modern Culture, 1450-1690, edited by James Daybell and Andrew Gordon, 1-20. New York: Routledge, 2016.

DeVos, Jessica. “Authenticity, Artifice, and Ovid's Heroides in Mary Stuart's Casket Sonnets." French Studies 71, no. 4 (2017): 489-508.

Dilworth, Mark. "Beaton, James." In Oxford Dictionary of National Biography. Oxford University Press, 2004; online ed., 2004. https://doi-org.proxy.library.carleton.ca/10.1093/ref:odnb/1825

Donaldson, Gordon. All the Queen's Men: Power and Politics in Mary Stuart's Scotland. New York: St. Martin's Press, 1983.

Durkan, John. “The Library of Mary, Queen of Scots." In Mary Stuart, Queen in Three Kingdoms, edited by Michael Lynch, 71-104. Oxford: Basil Blackwell, 1988. 
Frye, Susan. "Sewing Connections: Elizabeth Tudor, Mary Stuart, Elizabeth Talbot and Seventeenth-Century Anonymous Needleworkers." In Maids and Mistresses, Cousins and Queens: Women's Alliances in Early Modern England, edited by Susan Frye and Karen Robertson, 165-182. Oxford: Oxford University Press, 1999.

Glenn, Cheryl. Rhetoric Retold: Regendering the tradition from antiquity through the Renaissance. Carbondale: Southern Illinois University Press, 1997.

Gordon, Andrew. "Material Fictions: Counterfeit Correspondence and the Culture of Copying in Early Modern Britain.” In Cultures of Correspondence in Early Modern Britain, edited by James Daybell and Andrew Gordon, 85-109. Philadelphia: University of Pennsylvania Press, 2016.

Guy, John. Queen of Scots: The True Life of Mary Stuart. New York: Mariner, 2004.

Henderson, Thomas Finlayson. The Casket Letters and Mary Queen of Scots. Edinburgh, 1890.

Hennings, Jan. "Textual Ambassadors and Ambassadorial Texts: Literary Representation and Diplomatic Practice in George Turberville's and Thomas Randolph's Accounts of Russia." In Cultures of Diplomacy and Literary Writing in the Early Modern World, edited by Tracey Sowerby and Joanna Craigwood, 175-189. Oxford: Oxford University Press, 2019.

Keith, Reverend Robert. An Historical Catalogue of the Scottish Bishops Down to the Year 1688. Edinburgh: Bell \& Bradfute, 1824.

LaBouff, Nicole. "Embroidery and Information Management: The Needlework of Mary Queen of Scots and Bess of Hardwick Reconsidered." Huntington Library Quarterly, 83, no. 1 (August 2018): 315-358.

Lanham, Richard A. A Handlist of Rhetorical Terms: A Guide for Students of English Literature. Berkley: University of California Press, 1969.

Lloyd, Martin. The Passport: The History of Man's Most Travelled Document. Canterbury: Queen Anne's Fan, 2016.

Marcus, Leah S., Janel Mueller and Mary Beth Rose. "Preface." In Elizabeth I: Collected Works, edited by Leah S. Marcus, Janel Mueller and Mary Beth Rose, xixxiv. Chicago, University of Chicago Press: 2000.

Mueller, Janel. "Virtue and Virtuality: Gender in the Self-Representations of Queen Elizabeth I." In Virtual Gender: Fantasies of Subjectivity and Embodiment, 
edited by Mary Ann O’Farrell, Lynne Vollone, 220-246. Ann Arbor: University of Michigan Press, 1999.

Shrank, Cathy. "“This fatall Medea,' 'this Clytemnestra': Reading and the Detection of Mary Queen of Scots.” The Huntington Library Quarterly 73, no. 3 (2010): 523541.

Smith, Rosalind. “'Le pouvoir de faire dire': Marginalia in Mary Queen of Scots' Book of Hours." In Material Culture of Early Modern Women's Writing, edited by Patricia Pender and Rosalind Smith, 55-75. New York: Palgrave Macmillian, 2014.

Sowerby, Tracey A. "Negotiating with the Material Text: Royal Correspondence between England and the Wider World." In Cultures of Diplomacy and Literary Writing in the Early Modern World, edited by Tracey Sowerby and Joanna Craigwood, 203-219. Oxford: Oxford University Press, 2019.

Sowerby, Tracey A. and Joanna Craigwood. "Introduction," In Cultures of Diplomacy and Literary Writing in the Early Modern World, edited by Tracey Sowerby and Joanna Craigwood, 1-21. Oxford: Oxford University Press, 2019.

Strickland, Agnes. Lives of the Queens of England, Vol. 6. London: Henry Colburn, 1843.

Van Houdt, Toon and Jan Papy. "Introduction." In Self Presentation and Social Identification: The Rhetorics and Pragmatics of Letter Writing in Early Modern Times, edited by Toon Van Houdt, Jan Papy, Gilbert Tournoy and Constant Matheeussen, 1-16. Leuven: Leuven University Press, 2002.

Walton, Kristen Post. Catholic Queen, Protestant Patriarchy: Mary, Queen of Scots, and the Politics of Gender and Religion. New York: Palgrave Macmillan, 2007.

Warnicke, Retha. Mary Queen of Scots. New York: Routledge, 2006.

White, Allan. "Gordon, John, eleventh Earl of Sutherland." In Oxford Dictionary of National Biography. Oxford University Press, 2004; online ed., 2010. https://doi-org.proxy.library.carleton.ca/10.1093/ref:odnb/11060.

Zemon Davis, Natalie. The Return of Martin Guerre. Cambridge: Harvard University Press, 1983. 